OAK RIDGE NATIONAL LABORATORY

operated by

UNION CARBIDE CORPORATION

for the

U.S. ATOMIC ENERGY COMMISSION

ORNL-NSIC-25

UC-80 - Reactor Technology

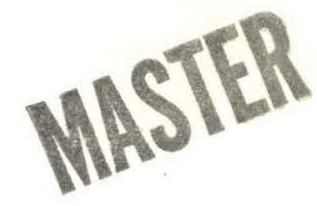

\title{
AIR CLEANING AS AN ENGINEERED SAFETY FEATURE IN LIGHT-WATER-COOLED POWER REACTORS
}

\author{
G. W. Keilholtz C. E. Guthrie \\ G. C. Battle, Jr.
}




\section{DISCLAIMER}

This report was prepared as an account of work sponsored by an agency of the United States Government. Neither the United States Government nor any agency Thereof, nor any of their employees, makes any warranty, express or implied, or assumes any legal liability or responsibility for the accuracy, completeness, or usefulness of any information, apparatus, product, or process disclosed, or represents that its use would not infringe privately owned rights. Reference herein to any specific commercial product, process, or service by trade name, trademark, manufacturer, or otherwise does not necessarily constitute or imply its endorsement, recommendation, or favoring by the United States Government or any agency thereof. The views and opinions of authors expressed herein do not necessarily state or reflect those of the United States Government or any agency thereof. 


\section{DISCLAIMER}

Portions of this document may be illegible in electronic image products. Images are produced from the best available original document. 
Printed in the United States of America. Available from Clearinghouse for Federal

Scientific and Technical Information, National Bureau of Standards,

U.S. Department of Commerce, Springfield, Virginia 22151

Price: Printed Copy $\$ 3.00$; Microfiche $\$ 0.65$

LEGAL NOTICE

This report was prepared as an account of Government sponsored work. Neither the United States, nor the Commission, nor any person acting on behalf of the Commission:

A. Makes any warranty or representation, expressed or implied, with respect to the accuracy, completeness, or usefulness of the information contained in this report, or that the use of any information, apparatus, method, or process disclosed in this report may not infringe privately owned rights; or

B. Assumes any liabilities with respect to the use of, or for damages resulting from the use of any information, apparatus, method, or process disclosed in this report.

As used in the above, "person acting on behalf of the Commission" includes any employee or contractor of the Commission, or employee of such contractor, to the extent that such employee or contractor of the Commission, or employee of such contractor prepares, disseminates, or provides access to, any information pursuant to his employment or contract with the Commission, or his employment with such contractor. 
Contract No. W-7405-eng-26

Nuclear Safety Information Center

AIR CLEANING AS AN ENGINEERED SAFETY FEATURE IN LIGHT-WATER-COOLED POWER REACTORS

G. W. Keitholtz C. E. Guthrie

G. C. Battle, Jr.

\section{LFGAL NOTICE}

This report was prepared as an account of Government sponsored work. Nelther the United States, nor the Commission, nor any person acting on behalf of the Commisslon:

A. Makes any war ranty or representation. expressed or implied, wl th respect to the accurary, completeness, or usefulness of the information contalned in this report, or that the use of any information, apparatus, method, or prucess diacloood in this report may not infringe privately owned rights; or

B. Assumes any liablitiles with respect to the use of, or for damages resulting from the use of any information, apparatus, method, or procesis disclosed in thls report.

As used In the above, "person acting on behalf of the Commission" Includes any employee or contractor of the Commission, or employee of such contractor, to the extent that ployee or contractor of the Commission, or employee of such contractor, to the extent that
oudh omplnyes ar contractor of the Commiesion, or employee of such contractor prepares, ouoh ompinyes ar contractor of the Commiasion, or employee of such contractor prepares,
disseminates, or provides access to, any infor miation fursuaut w hio omployment ar rinntract with the Commisston, or his employment with such cuistractor.

SEPTEMBER 1968

\footnotetext{
OAK RIDGE NATIONAL LABORATORY

Oak Ridge, Tennessee operated by

UNION CARBIDE CORPORATION

for the
}

U.S. ATOMIC ENFFRIY LUMINISSION 


\section{THIS PAGE}

\section{WAS INTENTIONALLY \\ LEFT BLANK}


FOREWORD

The recent surge in the building of large nuclear power plants, particularly with the projected desirability of using urban sites for such installations, has focused attention on many aspects of the AEC's responsibilities for licensing reactors and insuring the public safety. Since the industry is "young," meaningful, long-term operating experience is sparse and the definition of the possible accident spectrum, as well as a set of firm design requirements, is subject to a largely analytical approach that necessarily involves conservative judgments. As plant designs become standardized and operating experience on the newer large reactors is gained, the inevitable process of refinement and of acquiring confidence in the operation of the plants will occur. This relatively slow evolutionary approach to acquiring firm design standards and criteria is not felt to be conducive to achieving the great national benefits of atomic energy within a reasonable time, in terms of the conservation of resources, combating air pollution, and the multitude of gains resulting from low-cost electricity.

As part of the effort to improve on this approach, the Regulatory Review (Mitchell) Panel recommended the formation by the AEC of a Steering Committee on Reactor Safety Research to coordinate the needs of the Regulatory Program with the direction of the safety research and development programs. This committee, in turn, recommended that several studies be undertaken to provide guidance for the research and development projects, and this was, in turn, implemented by the AEC Division of Reactor Development and Technology into the series of discussion repurts herein described. It was intended that these reports provide a comprehensive assessment of the present status of specific aspects of nuclear safety and, by identifying accepted technology and the technology needing further experimental verification, that they enhance the understanding and confidence in this new industry.

Accordingly a number of the safety aspects of large light-water power reactors were selected by the $\mathrm{AEC}^{*}$ as subjects for detailed study to

*Letter from Milton Shaw (Director, AEC Division of Reactor Development and T'echnology) to ORIL, March 28, 1960. 
ascertain whether gaps in knowledge exist and where a research and development program could be of benefit. The subjects selected cover many of the areas for which inadequate factual bases exist and in which research that duplicates expected conditions is very difficult to perform. In general the subjects are in areas considered critical in the safety analysis of power reactor installations. Eight subjects were identified and a state-of-technology type of discussion report was prepared on each. The reports, which are directed primarily toward a technical-management audience, generally compare existing or planned plant applications with what is capable of being done at this time. Such comparisons have helped to identify inadequacies in assumptions, available data, or general basic knowledge so that, together with the opinions of experts in a particular field, areas of meaningful research and development have been identified. This report is one of the series of eight companion reports listed below:

Title

Missile Generation and Protection in Light-Water-Cooled Power Reactor Plants

Potential Metal-Water Reactions in Light-Water-Cooled Power Reactors

Emergency Core-Cooling Systems for Light-Water-Cooled Power Reactors

Air Cleaning as an Engineered Safety Feature in Light-Water-Cooled Power Reactors

Testing of Containment Systems Used with Light-Water-Cooled Power Reactors

Revièw of Methods of Mitigating Spread of Radioactivity from a Failed Containment System

Earthquakes and Nuclear Power Plant Design,

Protection Instrumentation Systems in Light-Water-Cooled Power Reactor Plants
ORNL-NSIC

Author

No.

R. C. Gwaltney

22

H. A. McLain

23

C. G. Lawson 24

G. W. Keilholtz, 25

C. E. Guthrie, and

G. C. Battle, Jr.

F. C. Zapp 26

R. C. Robertson

27

T. F. Lomenick and

28

C. G. Bell

C. S. Walker

29 
Although not specifically one of this series, a related discussion report on reactor pressure vessels, ORNL-NSIC-2l, edited by G. D. Whitman, G. C. Robinson, and A. W. Savolainen, has also been prepared at ORNL.

The general approach in the preparation of these reports was to select a primary author-investigator knowledgeable in the subject area and to establish committees of experts to review the work at several stages during its preparation. Review groups were formed both from within ORNL and outside. The external review committee members were drawn principally from other national laboratories, universities, and private research institutes - in all, 52 individuals participated and are identified in the reports. In some cases, part of the material used was developed and/or written by a subcontractor, who is similarly identified. In all cases, correspondence and/or visits were made to many sources of information, particularly to reactor operators, suppliers, architect-engineers, and public utilities, as well as to the appropriate national laboratories. This wide use of acknowledged experts was made in an attempt to include their opinions and knowledge toward the ultimate goal of achieving, through intensive research and development programs, well-defined design criteria to insure the public health and safety and to maintain a viable nuclear power industry. However, in all instances the authors have expressed conclusions and recommendations that reflect their own judgment and not that of any particular group, such as the AEC, reactor designers, or utilities.

In most subject areas more information was developed than it has been possible to include in the body of the reports prepared in this series. In some instances, such information has been included in the appendices and in other instances this information will be included in more technically oriented reports to be published in the near future. In addition, it is expected that additional discussion reports will be written on some of the many other safety aspects of large water-cooled reactors, as well as other tiypes of reactors as they come into wider usage.

J. W. Michel

Coordinator, Discussion Papers

Oak Ridge National Laboratory

Wm. B. Cottrell

Director, Nuclear Safety Program Oak Ridge National Laboratory 
THIS PAGE

\section{WAS INTENTIONALLY LEFT BLANK}




\section{PREFACE}

The Nuclear Safety Information Center was established in March 1963 at the Oak Ridge National Laboratory under the sponsorship of the U.S. Atomic Energy Commission to serve as a focal point for the collection, storage, evaluation, and dissemination of nuclear safety information. A system of keywords is used to index the information cataloged by the Center. The title, author, installation, abstract, and keywords for each document reviewed is recorded on magnetic tape at the central computer facility in Oak Ridge. The references are cataloged according to the following categories:

1. General Safety Criteria

2. Siting of Nuclear Facilities

3. Transportation and Handling of Radioactive Materials

4. Aerospace Safety

5. Accident Analysis

6. Reactor Transients, Kinetics, and Stability

7. Fission Product Release, Transport, and Removal

8. Sources of Energy Release Under Accident Conditions

9. Nuclear Instrumentation, Control, and Safety Systems

10. Electrical Power Systems

11. Containment of Nuclear Facilities

12. Plant Safety Features

13. Radiochemical Plant Safety

14. Radionuclide Release and Movement in the Environment

15. Environmental Surveys, Monitoring and Radiation Exposure of Man

16. Meteorological Considerations

17. Operational Safety and Experience

18. Safety Analysis and Design Reports

19. Bibliographies

Computer programs have been developed that enable NSIC to (1) produce a quarterly indexed bibliography of its accessions (issued with ORNL-NSIC report numbers); (2) operate a routine program of Selective Dissemination of Information (SDI) to individuals according to their particular profile of interest; and (3) make retrospective searches of the references on the tapes.

Other services of the Center include principally (1) preparation of state-of-the-art reports (issued with ORNL-NSIC report numbers); (2) cooperation in the preparation of the bimonthly technical progress review, Nuclear Safety; (3) answering technical inquiries as time is available, and (4) providing counsel and guidance on nuclear safety problems. 
Services of the NSIC are available without charge to government agencies, research and educational institutions, and the nuclear industry. Under no circumstances do these services include furnishing copies of any documents (except NSIC reports); although all documents may be examined at the Center by qualified personnel. Inquiries concerning 'the capabilities and operation of the Center may be addressed to

J. R. Buchanan, Assistant Director Nuclear Safety Information Center Oak Ridge National Laboratory Post Office Box $Y$ Oak Ridge, Tennessee 37830 Phone 615-483-8611, Ext. 3-7253 FTS 615-483-7253 


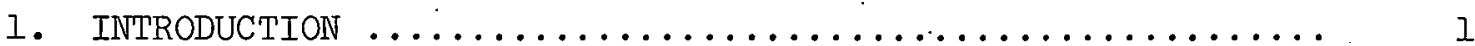

2. THE ROLE OF AIR CLEANING IN REACTOR SITING ............ 4

2.I Application of Air-Cleaning Methods to Particu-

lates, Iodine, and Noble Gases ............... 5

2.1.1 Filtration of Particulates .............. 6

2.1.2 Sorption and. Solution of Iodine and Other Reactive Gases ................. 6

2.1.3 Treatment of Noble Gases ............... 7

2.2 Credit Assumptions, for Current Reactors ........... 8

2.2.1 Efficiencies of Once-Through FilterAdsorber Systems in Secondary Containment Exhaust Lines ................... 8

2.2.2 Efficiencies of Recirculating FilterAdsorber Systems Within the Containment Shell ........................... 9

2.2.3 Efficiencies of Chemical Spray Systems ....... 10 References .............................. 10

3. RELATIONSHIP OF AIR-CLEAINING SYSTEMS TO CONTAINMENT STRUCTURES AND COOLING SYSTEMS ................. 13

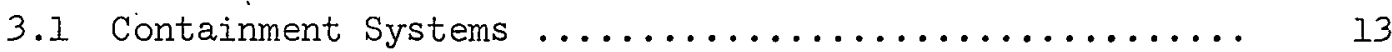

3.1.1 Pressure Containment .................... 14

3.1.? Pressure Containment with Secondary Containument ....................... 14

3.1.3 Propused Double Containment with Pumpkick ..... 15

3.1.4 Pressure-Suppression Containment with Secondary Containment ............... 15

3.1.5 Proposed Ice Condenser Containment .......... 17

3.2 Containment Shell Cooling Systems ............. 17

3.2 .1 Cooling-Co1l Systeins $\ldots \ldots \ldots \ldots \ldots \ldots \ldots \ldots \ldots$.

3.2.2 Spray Cooling Systems ............... 18 
3.3 Air-Cleaning Systems Predominating in Current

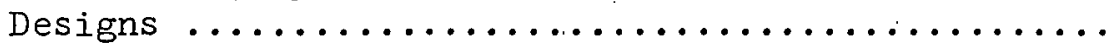

3.3.1 Once-Through Filter-Adsorber Systems in

Secondary Containment Exhaust Lines ........ 19

3.3.2 Recirculating Air.Filter-Adsorber Systems

Within the Containment Shell ........... 2I

3.4 New Applications and Proposed Air-Cleaning Systems ... 25

3.4.1 Once-Through Systems in Containment Shell

Exhaust Lines ...................... 25

3.4.2 Chemical Spray Systems and Pressure-

Suppression Pools .................. 27

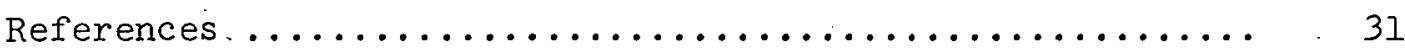

4. PERFORMAINCE AND TESTING OF HEPA FILTERS .............. 34

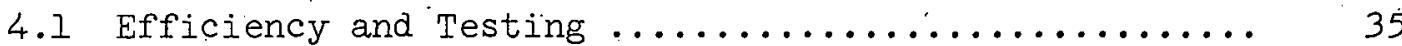

4.1.1 Preinstallation Efficiency Testing of

HEPA Filter Units ................. 36

4.1.2 Efficiency of HEPA Filter Media Under

Simulated Postaccident Conditions .......... 38 .

4.2 Filter Performance Under Operating Conditions ....... 40

4.2.1 Protection of HEPA Filters from Moisture

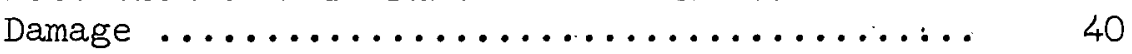

4.2.2 Resistance to. Fire and Hot Air ............ 42

4.2.3 Resistance to Shock Waves ............... 43

4.2.4 Kesistance to Accident-Produced Pressure:

Differentials.................... 46

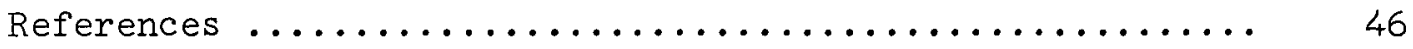

5. PERFORMANCE AND TESTING OF CHARCOAL ADSORBERS . . . . . . . 4.9

5.I Efficiency 'l'esting of New and Recharged Char-

coal Beds ..............................

5.2 Efficiency for Molecular Iodine Removal Under

Simulated Postaccident Conditions .............. 52

5.3 Efficiency for Methyl Iodide Removal Under.

Simulated postaccident Conditions ............... 54

5.3.1 Conventional Activated Charcoals ........... 55

5.3.2 Commercial Impregnated Charcoals ........... 56

5.3.3 Differences Between U.S. Recommended Charcoals and Those Recommended by the UKAEA

Reactor Development Laboratory ........... 58

5.3.4 Use of Unimpregnated Charcoals at the

Savannah River Plant ................... 
5.4 Prevention of Charcoal Ignition ............... 59

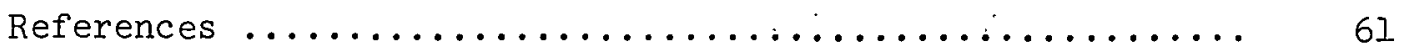

6. PERFORMANCE AND TESTING OF FILTER-ADSORBER SYSTEMS ....... 65

6.1 In-Place Testing of Filter-Adsorber Systems ......... 65

6.1.I In-Place Testing of HEPA Filter Syștems ...... 66

6.1.2 In-Place Testing of Adsorber Systems ........ 68

6.2 Operating Conditions ....................... 69

6.2.1 Once-Through Systems in Secondary Containment Exhaust Lines ................. 69

6.2.2 Once-Through Systems in Containment Shell Exhaust Lines .................. 70

6.2.3 Recirculating Systems Within the Containment Shell ..................... 71

6.3 Performance of System Components ..................... 71

6.3.1 Effect of Humidity on Agglomerate Size and Filterability ................. 71

6.3.2 Use of Heater to Reduce Humidity in Charcoal Beds ..................... 73

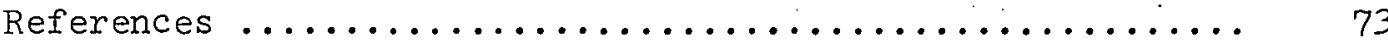

7. AIR CLEANUP POTEIVTIAL OF CHEMICAL SPRAY SYSTEMS ......... 75

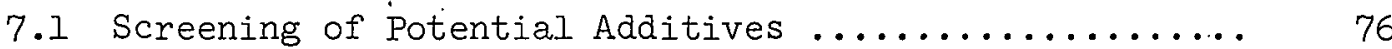

7.1.1 Theoretical Examination of Iodine-Water Partition Coefficients ............... 77

7.1.2 Measurement of Distribution Coefficients for Various Additives ............... 78

7.1.3 Work on Additional Compounds, Reaction Froducts, drud Temperalure Erfecls ...........

7.2 Uptake of $\mathrm{I}_{2}$ and $\mathrm{CH}_{3} \mathrm{I}$ by Single Drops of Water Solution Suspended in a Wind Tunnel............. 85

7.3 Spray Tests in the Nuclear Safety Pilot Plant ....... 86

.7.4 Analytical Models of Iodine Removal by Sprays ........ 87

7.5 Radiation Stability of spray Solutions ............. 90

7.5.1. Effect of Radiation on $\mathrm{pH}, \mathrm{I}_{2}$ Equivalence, and Solids Formation .................. 90

7.5.2 Radiolytic Hydrogen Production ............ 91

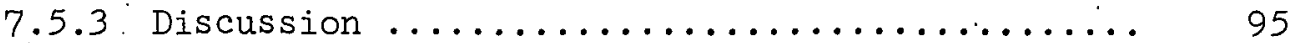

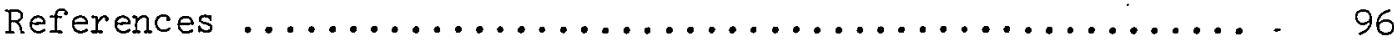


8. AIR CLEANUP POTEITTAL OF PRESSURE-SUPPRESSION POOLS ....... 99

8.1 Scavenging of Fission Products by Suppression

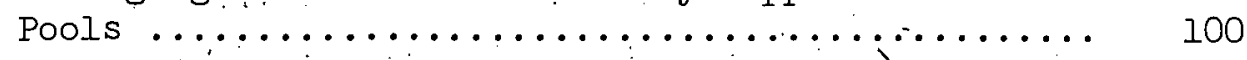

8.2 Model Tests of Scavenging by Pressure-

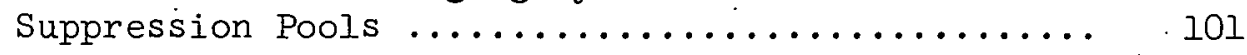

8.3 Pressure-Suppression Tests in the CSE ........... 103

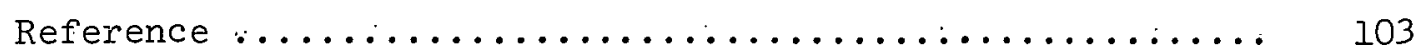

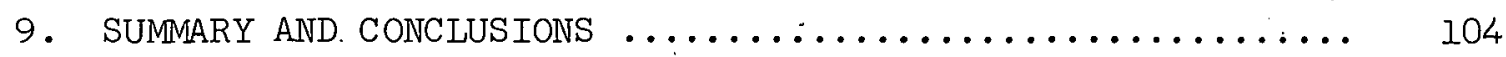

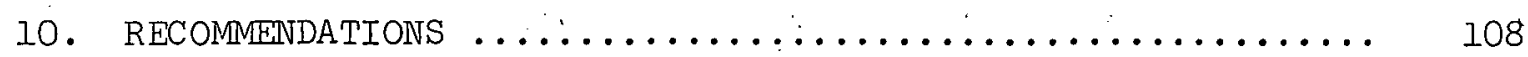

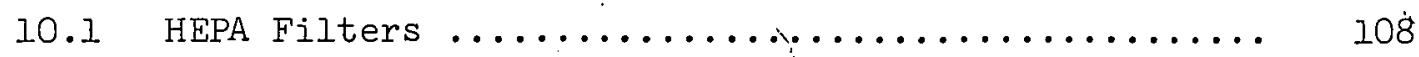

10.2 Activated Charcoal and Chemical Adsorbers ......... 108

10.3 Once-Through Filter-Adsorber Systems ........... . 108

10.4 Recirculating Filter-Adsorber Systems ........... 109

10.5 Standby Filter-Adsorber Systems ............... 109

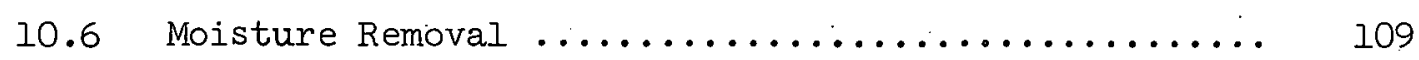

10.7 Chemical Sprays and Spray Systems ............. 109

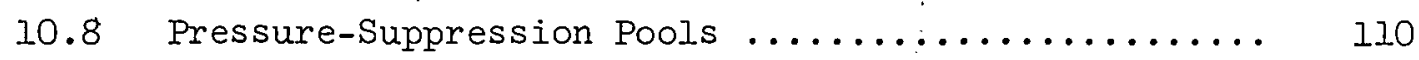

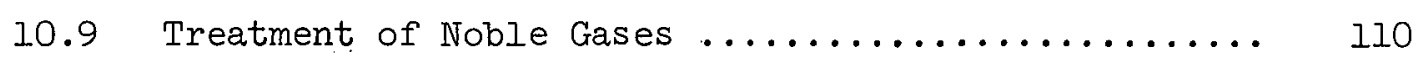

10.10 Reliability of Aị-Cleaning. Systems ............... 110

10.11 Simulation, Characterization, and Transport

$\perp U . \perp 2$ Ana $\perp y t i c a \perp$ Models and Applications of Theory ....... 111. APPENDIX A. BIBLIOGRAPHY OF SUBJECTS REIATED TO FISSIONPRODUCT TRAPPING IN PRESSURE-SUPPRESSION POOLS .... 115

APPENDIX B. REVIEW COMMITTEES AND CONSULTANTS ........... 127 
The safety features of air-cleaning systems for use after postulated lose-of-coolant accidents or other design-basis accidents in water-cooled power reactors are discussed. The capabilities and limitations of highefficiency air filters and charcoal adsorbers both in recirculating systems (for reducing the concentration of radioiodine and particulate fission products in the atmosphere within the containment shell after an accident) and in once-through systems (for removing fission products from the secondary containment structure surrounding the containment shell) are reviewed. The air-cleaning potentials of containment-cooling sprays and pressure-suppression pools are also discussed. Important considerations in the use of air cleaning systems as engineered safety features are their effectiveness and their performance under accident conditions, including radiation, thermal transients; abnormal pressures, pressure surges, missiles, and corrosion. To be effective as an engineered safety feature, an air-cleaning system must either rapidly reduce the fission-product concentration in the containment shell (to significantly reduce the amount of fission-product leakage) or efficiently trap fission products that have leaked from the containment shell into the secondary container (to prevent their release to the environment). The most widely used methods provided for treating fission products after an accident are trapping of particulates by prefilters and HEPA filters, trapping of iodine by activated charcoal; and retention of noble gases until they have decayed to acceptable levels, followed by gradual, controlled release from a tall stack. At the present time filter systems are further developed and more generally accepted as an engineered safety feature than containment sprays, but current research may show that sprays may be more desirable, especially for iodine removal. 


\section{INTRODUCTION}

Siting of nuclear power reactors is influenced by the potential hazard of released fission products. The containment of these radioactive particulates and gases is essential to the safe operation of such installations.

Air cleaning is used in two ways as an engineered safety feature in water-cooled reactors: (1) recirculating systems in the containment shell are used to reduce the concontration of airborne fission products in the containment atmosphere after an accident and thereby reduce fission-product leakage from the containment system, and (2) once-through (single-pass) systems in the secondary containment building or volume are used to collect and retain any fission products that have leaked from the containment shell (or directly from the primary cooling system in some possible accidents in boiling-water reactors). Use of the oncethrough system reduces dispersal of fission products to the environment and simultaneously relieves pressure buildup in the secondary containment structure by releasing the air or other gas to the atmosphere.

For the design of air-cleaning systems as engineered safety features', a loss-of-coolant accident followed by at least partial core meltdown has been widely used as the design-basis accident; although other types of accidents are also considered. Important considerations in the use of aircleaning systems as engineered safety features that mitigate the consequences of such accidents are their effectiveness, their reliability, and their resistance to radiation, thermal transients, abnormal pressures, pressure surges, missiles, and corrosion under the accident conditions.

The design of the air-cleaning system or systems for a given reactor is integrally related to the design of its containment system. The containment system can be defined as the reactor containment structure and assnciated engineered safety systems and components that are provided to maintain its integrity. The basic envelope that surrounds a reactor may be one of many types. Those predominate in the power reactor field in the United states are steel pressure shells and various types of concrete structures with steel liners. These structures are provided with various 
penetrations, including equipment and personnel air locks, electrical and instrument penetrations, and piping penetrations, together with their associated isolation valves. The penetrations are carefully designed to maintain the integrity of the system.

Two basic containment concepts have been used predominantly with water-cooled power reactors in the United States: pressure containment and pressure-suppression containment. A modification of pressure containment is multiple-barrier containment. Pressure containment, which utilizes a single-barrier steel shell to enclose the reactor vessel and piping and frequently many of the auxiliary systems, has been used for the majority of nuclear power plants built to date. Pressure-suppression containment is based on ducting the reactor coolant discharges from a hypothetical loss-of-coolant accident into a heat sink (usually a pool of water) to reduce the pressure and temperature inside the containment shell by condensing the steam-water mixture; a large percentage of the entrained fission products may be also removed in the pool water.

Multiple barriers, combined with the pressure-containment concept, have been proposed for containing power reactors to be located in urban areas. These concepts offer greater control of leakage than the single containment shell; further, they may have advantages in improved accuracy of leakage-rate testing and ease in performing continuous monitoring of the leakage rate. In the multiple-barrier concept, leakage past the first barrier (the containment shell) is collected within a reduced-pressure zone between the first and second barriers and is either exhausted through a. filter system and stack or pumped back inside the containment shell.

In water-cooled power reactors the primary cooling water is at high pressure and temperature; that is, about $1000 \mathrm{psi}$ and $500^{\circ} \mathrm{F}$ in boilingwater reactors and as high as about $2200 \mathrm{psi}$ and $600^{\circ} \mathrm{F}$ in pressurizedwater reactors. A loss-of-coolant accident is usually considered the most serious design-basis accident. In this postulated accident, a large pipe in the primary cooling system would rupture completely, the highpressure hot cooling water would be rapidly and freely discharged from both ends and flash into steam in the containment shell, and the sudden depressurization of the core would cause mechanical failure of fuel- 
element cladding and rapid release of fission products into the containment shell. If the emergency core-cooling system could not maintain enough core cooling, partial meltdown of fuel in the core would release more fission products and more energy into the containment shell. The resulting containment atmosphere is typically assumed to consist of steam, air, and fission products at about 40 to 50 psig and about $275^{\circ} \mathrm{F}$. While other engineered safety features are provided to reduce the pressure to atmospheric as rapidly as possible, and even though the design leakage rates of containment shells are low, air-cleaning systems are needed to minimize fission-product escape. If other engineered safety features were only partially effective, or if the containment leakage rate were higher than the design value, it would be especially important for the air-cleaning systems to function.

Spray cooling systems, recirculating air-cooling systems, and other heat-removal systems included as engineered safety features in containment shells are designed to reduce the pressure and temperature of the postaccident containment atmosphere as quickly as possible and thus minimize the release of fission products to the environment. Currently designed systems for removing fission products from the atmosphere of the containment shell are in most cases combined with the containment shell cooling systems by the addition of filters and adsorbers to the recirculating air-cooling systems and/or the addition of a chemical to the containment spray cooling system.

The fission products in the containment atmosphere following an accident can be divided primarily into three groups with respect to air cleaning: particulates, iodine and other chemically reactive gases, and noble gases. Methods of removing the fission products in each group from reactor containment atmospheres must take advantage of one or more physical or chemical properties of the group. The methods - either in use or under development - for handling each group of fission products are discussed in this report. Also, the available information on performance and integrity of the various systems and components is discussed in its relationship to reactor siting. 


\section{THE ROLE OF AIR CLEANING IN REACTOR SITING}

Several power reactors with outputs of over $1000 \mathrm{Mw}(e)$ each are scheduled for startup in 1970-71, and reactors of about $1500 \mathrm{Mw}(\mathrm{e}$ ) are being designed. The increase in numbers is increasing the probability that a major accident might occur, the increase in size is increasing the fission-product inventory in the average power reactor, and increases in both number and size are increasing the total amount of fission products that must be contained, within reason, to prevent excessive contamination of the earth's atmosphere.

With present technology it must be assumed that there will be releases of fission products from fuel elements, that these fission products may escape from the primary cooling system into the containment shell, and that the containment shell will have at least a small. leak. After a major accident in a typical boiling-water reactor enclosed in a pressure-suppression containment system surrounded by a secondary containment structure (the refueling building), most of the airborne fission products released into the secondary containment building would be removed by a once-through air-cleaning system through which the air would be exhausted to a stack. Once-through air-cleaning systems are also provided för pressurized-water reactors with secondary containment volumes, such as Indian Point 1 and the Oconee reactors, and for reactors having provision for slow purge of the containment atmosphere, such as Turkey Point Units 3 and 4 and the proposed Malibu reactor (which has double containment with pumpback into the inner containment shell):

After a major accident in a typical pressurized-water reactor with a single pressure-containment shell, the fission-product concentration of the atmosphere within the containment shell would be effectively renuced by a recirculating air-cleaning system, provided the accident or the postaccident environment within the containment system had not reduced its cleaning capability below an acceptable level. Chemical spray systems, which are being investigated as alternatives to recirculating filteradsorber systems, should be very reliable, but their effectiveness has not yet been fully evaluated. 
All these reactor containment systems are designed so that, if necessary, the containment shell could be kept sealed indefinitely if containment integrity were not breached and if the design pressure and leakage rate were not exceeded. However, the possibility of the pressure exceeding the design pressure and of the leakage exceeding the design rate must be guarded against by air-cleaning systems. Furthermore, the closer a reactor is to a population center, the larger the center, and the higher the population density, the more restrictive must be the limits on the amount of fission products that could be released from the containment system. This applies not only to design-basis and other major accidents but also to lesser accidents and to releases small enough to be considered operational in nature. In order to comply with these restrictions, aircleaning systems must be designed, constructed, inspected, tested, and maintained so that they will perform effectively and reliably under any conditions to which they might be subjected.

Air-cleaning systems must be capable of effective and reliable operation both during the high-pressure high-temperature postaccident period and after pressure and temperature have returned to normal. As consequence-limiting engineered safety features, air-cleaning systems must assure continuing protection of the public regardless of whether it was found necessary to keep the containment sealed and the power plant shut down for a number of years or whether it was found that decontamination, repairs, and necessary replacements could be effected. In the latter case, cleaning of containment air would be necessary after most or all accidents, even if fission-product release had been held within acceptable limits by the sealed containment shell without the use of the aircleaning system.

\subsection{Application of Air-Cleaning Methods to Particulates, Iodine, and Noble Gases}

Fission products can be divided primarily into three groups with respect to air cleaning: particulates, iodine and other chemically reactive gases and vapors, and noble gases. 


\subsubsection{Filtration of Particulates}

Particulates include aerosols, which may be suspended in the containment atmosphere, and larger particles, which may be entrained in air or steam flowing at high velocity. The larger particles are usually trapped by screens and relatively' coarse prefilters. These particles; which may contain various amounts of fission products, must be removed even if nonradioactive to prevent clogging of high-efficiency filters or charcoal adsorbers or other damage. Aerosols range in size from clusters of a few molecules to particles about $50 \mu$ in diameter. Aerosols produced in a postulated loss-of-coolant accident may be largely composed of fission products, $\mathrm{UO}_{2}$, and cladding materials that have volatilized from melting fuel and subsequently condensed and agglomerated in the containment atmosphere. They will probably carry water and reactive gases sorbed on their surfaces. The rate of agglomeration depends largely on particle concentration; particle size, humidity, and electrostatic charges. In reactor applications, particulates are removed predominantly by prefilters and HEPA filters: The abilities of containment atmosphere cooling sprays and pressure-suppréssion pools to collect particulate materials are currently being studied (see chap. 7).

\subsubsection{Sorption and Solution of Iodine and Other Reactive Gases}

The most important reactive gases are molecular iodine $\left(I_{2}\right)$ and two of its gaseous compounds, hydrogen iodide ( $\mathrm{HI}$ ) and methyl iodide ( $\mathrm{CH}_{3} \mathrm{I}$ ). The relative production of these three forms of iodine in an accident cannot yet be quantitatively predicted. ${ }^{1-5}$ When fuel meitdown occurs in an oxidizing atmosphere the iodine is primarily $\mathrm{I}_{2}$; in a reducing atmosphere it is primarily HI (or solid compounds, such as CsI). Investigations indicate that $\mathrm{CH}_{3} I$ is formed not during meltdown but by subsequent chemical reactions within the containment shell. The relative amounts of the three forms of iodine will depend on the containment atmosphere (air versus inert gas), the amount of hydrogen produced from metal-. water reactions, traces of organics in the fuel, and the amounts and types of organics in the containment shell. Methyl iodide and other organic iodine compounds are not likely to constitute more than a few percent of 
the total..$^{-4}$ Nevertheless, all three airborne forms of iodine must be removed as efficiently as possible. Other, much less important reactive gases are bromine and trace amounts of other fission-product compounds with vapor pressures high enough to volatilize them under accident conditions.

Since iodine and its gaseous compounds are reactive they can be removed by a variety of physical and chemical processes: adsorption, absorption, chemisorption, solution, etc. The processes that have proved most practical and are a part of current reactor plant design are sorption on activated charcoal (for $\mathrm{CH}_{3} \mathrm{I}$, impregnated charcoal) and scrubbing with a reactive solution. Iodine attached to particulate material can be removed by HEPA filters.

\subsubsection{Treatment of Noble Gases}

Because of their lack of chemical reactivity and their gaseous form, the noble gases xenon and krypton cannot currently be removed, in a practical way, from the containment shell atmosphere of a commercial reactor during the high-pressure high-temperature stage of a loss-ofcoolant accident. Their complcte removal from the secondary containment atmosphere would also be impractical at present because of their low concentrations and the large volume of air. The only currently practical method of minimizing the discharge of noble gases to the environment during the early stages of an accident is to retain them in a.low-leakage containment system. However, the effect of their release can be minimized by holdup for radioactive decay, followed by controlled discharge through a high stack. The methods described below would be applicable only to cleaning the containment atmosphere over several days following an accident.

The simplest proven method for the removal of xenon and krypton is adsorption on charcoal at room temperature. This requires a very large volume of charcoal. Adsorption on charcoal at or below the temperature of liquid nitrogen requires complex equipment of relatively small volume. ${ }^{7,8}$ In most cases, the main function of adsorption on charcoal is to delay the release of noble gas fission products long enough for them 
to decay to acceptable levels. Krypton-85, which has a half-life of about 10.3 years, is an exception; it is usually treated by high dilution and gradual or continuous release from a high stack in small quantities. Removal by solution in liquids ${ }^{9}$ has the advantages of a continuous process but requires large and complex equipment. Separation by selective permeability in a cascade of membranes ${ }^{10}$ shows promise but has not yet been proven economically feasible. Both absorption in a liquid fluorocarbon and concentration in a cascade of membranes are being evaluated for large-scale application and economic optimization. 11,12

\subsection{Credit Assumptions for Current Reactors}

From efficiencies assumed by the Division of Reactor Licensing (DRL) in the computation of radiation doses, in the accident analysis portions of safety evaluations and analyses for a number of current reactors, it may be inferred that credit is given in various amounts for the removal of iodine and particulates. In some cases the accident analyses state that DRL assumed certain efficiencies; in others they state that DRL considered certain assumptions by the applicant to be reasonable or conservative. In at least one case, the work credit was used. In a number of cases, it was stated that the potential consequences of accidents would be within i.o CFR 100 guidelines (the AEC site criterja) with the ef'ficiencies assumed. For one reactor system, it was stated that iodine-removal equipment might be needed in order to assure that $10 \mathrm{CFR} 100$ guidelines are met.

In 13 accident analyses cited in this report, reference was found to efficiency for the removal of solids in only two cases. Eleven reports contained references to efficiency for the removal of iodine or halogens. of the two remaining reports, one assumed a removal factor for iodine and the other stated that iodine-removal equipment might be necessary.

\subsubsection{Efficiencies of Once-Through Filter-Adsorber Systems in Secondary Containment Exhaust Lines}

A halogen-removal efficiency of $90 \%$ was assumed for the standby gastreatment system in the secondary containment building in five accident analyses (Dresden 2, Dresden 3; Millstone Point, Browns Ferry 1 and 2, 
and Vermont Yankee). 13-17 The applicant assumed $99 \%$ removal efficiencies for both halogens and solids for the Vermont Yankee reactor, but DRL assumed $90 \%$ for halogens and $95 \%$ for solids to make allowance for poor installation, deterioration of filter media and seals, accidental damage, accident conditions, etc. ${ }^{18}$ An efficiency of $95 \%$ was assumed for the re-. moval of halogens and solids by high-efficiency filters and charcoal beds in the reactor building of the Oyster Creek reactor. ${ }^{29}$ A solids-removal. efficiency of $95 \%$ was assumed for the standby gas-treatment system in the secondary containment building of the Vermont Yankee reactor. The safety evaluation for the Vermont Yankee reactor includes the reactors discussed in this paragraph in a listing of the current generation of General Electric Company boiling-water reactors. ${ }^{20}$

The standby gas-treatment system in the secondary containment buildings of Peach Bottom Units 2 and 3 was assumed to retain 90\% of the elemental iodine. 21 Elemental iodine was assumed to constitute $80 \%$ of the iodine leaking from the drywell; the other $20 \%$ was assumed to be in the organic form and not susceptible to retention by the gas-treatment system.

A halogen-removal efficiency of $90 \%$ was assumed for the penetrationroom filters of Oconee Units 1,2 , and 3 . One-half the containment shell leakage was assumed to pass through these filters. ${ }^{22}$

\subsubsection{Efficiencies of Recirculating Filter-Adsorber Systems Within the Containment Shell}

An achievable efficiency of 80 to $90 \%$ for the removal of organic iodides by impregnated charcoal beds in the containment atmosphere recirculating system of the Connecticut Yankee reactor was stated to have been demonstrated by the applicant, and the charcoal chosen was also stated to be well known to have excellent efficiency for the removal of elemental (molecular) iodine from atmospheres with relative humidities of $100 \% .^{23}$ An efficiency of $90 \%$ for elemental iodine was considered reasonable for charcoal beds in the recirculating system of the Indian Point 2 reactor, but zero efficiency was assumed for the removal of organic iodine. $^{24}$ However, the accident analyses stated that $10 \mathrm{CFR} 100$ guidelines could be satisfied under the assumed conditions with an efficiency 
of $45 \%$ in the case of Indian Point 2 (Ref. 24) and could be satisfied with only one of the four charcoal units operating and with an efficiency of less than 50\% in the case of Connecticut Yankee. ${ }^{25}$ The accident analysis for the Palisades reactor stated that iodine-removal equipment (charcoal system or thiosulfate spray system) might be needed in order to assure that $10 \mathrm{CFR} 100$ guidelines are met. 26

\subsubsection{Efficiencies of Chemical Spray Systems}

The removal of elemental iodine by a factor of 8.8 per hour by the sodium thiosulfate spray system in the H. B. Robinson 2 reactor was considered conservative, but the analysis also stated that it was expected that experiments to be performed on the iodine-removal system would demonstrate than an adequate removal rate is achievable. 27 As noted in section 2.2.2, above, it was stated for the Palisades reactor that iodine-removal equipment (charcoal or thiosulfate spray) might be needed. For the Indian Point 2 reactor, no credit was given for the containment spray system, into which sodium thiosulfate was to be injected. 24

\section{$\underline{\text { References }}$}

1. J. Mishima, Methyl Iodide Behavior in Systems Containing Airborne Radioiodine, Nucl. Safety, 9(1): 35 (1968).

2. J. Mishima, Review of Methyl Iodide Behavior in Systems Containing Airborne Radioiodine, USAEC Report BNWL-319, Pacific Northwest Laboratory, June 1966.

3. W. B. Cottrell; pp. xxii and 127, Nuclear Safety Program Annual Progress Report for Period Ending December 31, 1966, USAEC Report ORNL4071, Oak Ridge National Laboratory, March 1967.

4. G. W. Keilholtz, Filters, Sorbents, and Air Cleaning Systems as Engineered Safeguards in Nuclear Installations, USAEC Report ORNLNSIC-13, Oak Ridge National Laboratory, October 1966.

5. R. H. Barnes et al., Studies of Methyl Iodide Formation Under NuclearReactor-Accident Conditions, USAEC Report BMI-1829, Battelle Memorial Institute, February 1968.

6. G. W. Keilholtz, Removal of Radioactive Noble Gases from Off-Gas Streams, Nucl. Safety, 8(2): 155-160 (Winter 1966-1967). 
7. J. H. MacMillan, The Babcock \& Wilcox Company, unpublished information, Dec. 22, 1958.

8. Air Reduction Company, Inc., Noble Gas Recovery Study - Maritime Nuclear Ship SAVANNAH, Final Report, Apr. 5, 1965 (undocumented).

9. J. M. Holmes, Oak Ridge National Laboratory, unpublished information, Oct. 9, 1963.

10. S. Blumkin et al., Preliminary Results of Diffusion Membrane Studies. for the Separation of Noble Gases from Reactor Accident Atmospheres, paper presented at the Ninth AEC Air Cleaning Conferences, Boston, Mass., Sept. 13-16, 1966.

11. J. R. Merriman, J. H. Pashley, and S. H. Smiley, Engineering Development of an Absorption Process for the Concentration and Collection of Krypton and Xenon, Surmary of Progress Through July 1, 1967, USAEC Report K-1725, Oak Ridge Gaseous Diffusion Plant, December 1967.

12. R. H. Rainey, Separation of Noble Gases from Air by Permselective Membranes, pp. 173-1.82 in Nuclear Safety Program Ann. Progr. Rept. Dec. 31, 1967, USAEC Report ORNL-4228, Oak Ridge National Laboratory.

13. Safety Evaluation by the Division of Reactor Licensing in the Matter of Commonwealth Edison Company, Dresden Nuclear Power Station Unit 2, Grundy. County, Illinois, p. 48, Docket No. 50-237, Nov. 24, 1965.

14. Safety Evaluation by the Division of Reactor Licensing, USAEC, in the Matter of Commonwealth Edison Company, Dresden Nuclear Power Station. Unit 3, Grundy County, Illinois, p. 54, Docket No. 50-249, Aug. 31, 1966.

15. Safety Evaluation by the Division of Reactor Licensing, USAEC, in the Matter of the Connecticut Light and Power Company, the Hartford Electric Iight Company, the Western Massachusetts Electric Company, and the Millstone Point Company, as Participants in the Millstone Nuclear Puwer: Station, Waterford, Connecticut, pp. 52-53, Docket No. 50-2.45, Apr. 4, 1966.

16. Safety Analysis by the Division of Reactor Licensing, USAEC, in the Matter of the Tennessee Valley Authority, Browns Ferry Nuclear Power Station, Limestone County, Alabama, p. 28, Docket Nos. 50-259 and 50-260, Mar. 31, 1.967.

17. Saf'ety Evaluation by the Division of Reactor Licensing, USAEC, in the Matter of Vermont Yankee Nuclear Power Corporation, Vermont Yankee Nuclear Power Station, Vernon, Vermont, p. 31, Docket No. 50-271, July 7, 1967.

18. Tbid., App. I, p. 5. 
19. Hazards Analysis by the Research and Power Reactor Safety Branch, Division of Reactor Licensing, USAEC, in the Matter of Jersey Central Power and Light Company, Oyster Creek Nuclear Power Plant Unit No. I, pp. 42-45, Docket No. 50-219, Sept. 23, 1964.

20. Op. cit., Ref. 17, p. 32 .

21. Safety Evaluation by the Division of Reactor Licensing, USAEC, in the Matter of Philadelphia Electric Company, Peach Bottom-Atomic Power Station Units Nos. 2 and 3, Peach Bottom Township, York County, Pennsylvania, p. 34, Docket Nos. 50-277 and 50-278, Nov. 7, 1967.

22. Safety Analysis by the Division of Reactor Licensing, USAEC, in the Matter of Duke Power Company, Oconee Nuclear Station Units 1, 2, and 3, Oconee County, South Carolina, p. 68, Docket Nos. 50-269, 50-270, and 50-287, Aug. 4, 1967.

23. Safety Evaluation by the Division of Reactor Licensing, USAEC, in the Matter of Connecticut Yankee Atomic Power Company, Haddam Neck Plant, p. 9, Docket No. 50-213, Apr. 13, 1967.

24. Safety Evaluation by the Division of Reactor Licensing, USAEC, in the Matter of Consolidated Edison Company of New York, Inc., Indian Point Nuclear Generating Unit No: 2, Feekskill, New York, pp. 63-65, Docket No. 50-247, Aug. 25, 1966.

25. Op. cit., Ref. 23, pp. 37-38.

26. Safety Analysis by the Test and Power Reactor Safety Branch, Division of Reactor Licensing, USAEC, in the Matter of Consumers Power Company, Palisades Plant, p. 35, Dnrket. No. 50-255, Fel. 7, 196\%.

27. Sufety Analysis by the Division of Reactor Licensing, USAEC, in the Matter of Carolina Power and Light Company, H. B. Robinson Unit No. 2, Darlington County, South Carolina, pp. 22-23, Docket No. 50-261, Feb. 27, 1967. 


\section{RELATIONSHIP OF AIR-CLEANING SYSTEMS TO CONTAINMENT STRUCTURES AND COOLING SYSTEMS}

In water-cooled power reactors, the principal governing factor in the selection of the type of air-cleaning system to be used for a specific reactor has been the type of containment selected for that reactor. Oncethrough air-cleaning systems have, with a few very recent exceptions, been applied only to reactors that have a secondary containment structure enclosing most or all of the containment shell. Air-cleaning systems within the containment shell have almost all been combined with the containment cooling systems.

Containment structures and their cooling systems have, in recent years, become rather standardized. However, the economic desirability of increasing the power of reactors, lengthening their fuel cycles, and locating them closer to metropolitan power consumers has accelerated the continuing nuclear safety research and development directed toward further increases in the effectiveness and reliability of engineered safety features. This trend has generated new containment designs and concepts, has produced at least one new system for the reduction of postaccident pressure and temperature, and has emphasized the increasing need for aircleaning systems and for improvements in their performance and reliability. The relationship of containment structures and cooling systems to aircleaning systems used as engineered safety features and the influence of recent trends in reactor design and. siting are examined in this chapter.

\subsection{Containment Systems}

In current practice in the United States, two basic types of containment systems are applied to water-cooled power reactors. Pressure containment is used for pressurized-water reactors and a few boiling-water reactors, and pressure-suppression containment with secondary containment is used exclusively for direct-cycle boiling-water reactors. Recently, however, an ice condenser containment system was developed, and double containment with pumpback is again under consideration. 
The order of presentation in this section is by containment type, rather than frequency of use. A discussion of simple pressure containment is followed by discussions of two containment systems that include pressure containment. Pressure-suppression containment is discussed next, and a discussion of ice-condenser containment follows; the ice condenser is expected to be capable, in a very high degree, of the rapid reduction of containment pressure and temperature characteristic of pressure-suppression systems.

\subsubsection{Pressure Containment}

Pressure containment shells are usually spherical steel pressure shells or domed cylinders of reinforced concrete with steel liners. Both types are designed to withstand the temperature and pressure (about 40 to 50 psig) resulting from the flashing of all the primary coolant into the containment shell.

Pressure containment is used for some boiling-water power reactors (such as Dresden 1 and Big Rock Point ${ }^{1,2}$ ) and is currently applied to pressurized-water power reactors in general. The containment shell of the Yankee Reactor, ${ }^{3}$ one of the early (1960 startup) power reactors, is an example of the spherical steel shell type. The containment shells of the Turkey Point 3 and 4 reactors ${ }^{4}$ (1971-197.2 startup) and the Indian Point 2 reactor ${ }^{5}$ (1969 startup) are examples of the steel-lined concrete cylinder type. The Indian Point 2 containment shell provides pressurization of welds and penetrations to assure a low leakage rate.

For pressurized-water reactors, a maximum acceptable design-basisaccident leakage rate (usually 0.1 wt $\%$ of the contained volume per $24 \mathrm{hr}$ ) is specified for the shell at the maximum design-basis-accident temperature and pressure. 6

\subsubsection{Pressure Containment with Secondary Containment}

In a modification of the pressure containment system, a secondary enclosure is placed entirely or partially around the containment shell. The containment shell serves the same purpose as in simple pressure containment; however, any leakage from it is to the volume between the two 
structures, in which fission products can be held up for radioactive decay, diluted with outside air from secondary containment inleakage or supply fans, cleaned by a filter-adsorber system, and exhausted through a high stack. This type of containment is not yet in wide usage for water-cooled power reactors.

The Indian Point 1 reactor ${ }^{7}$ (1962 startup) has a spherical steel pressure containment shell completely surrounded by a domed reinforced-concrete cylinder, with an annular space between the two. The annulus was provided for concrete forming, and its capability for retention of leakage was not exploited or required to meet initial siting requirements. It is, however, vented through HEPA filters to the stack and thus provides secondary containment. 8

Each of the Oconee reactors $\mathrm{s}^{9}$ (1971-1972 startup) also has a.spherical steel containment shell, but the secondary containment is a penetration room attached to the outside of the containment shell. in a position to enclose many of the containment shell penetrations.

\subsubsection{Proposed Double Containment with Pumpback}

Another modification of pressure containment, once proposed for the Ravenswood reactor and now proposed for the Malibu reactor, ${ }^{10}$ is double containment with pumpback. This containment system will have two domed steel cylinders separated by a 20-in.-thick annulus filled with porous concrete. The annulus will be kept at a pressure slightly lower than that of the outside air, and any leakage will be pumped back into the inner containment shell. If it were necessary to vent the inner shell to the outsiue alinusplere, the air could be cleaned, monitored, and exhausted through the stack. However, if the concentration of fission products exceeded permissible limits for release to unrestricted areas, any atmosphere removed from the inner containment shell would be transferred into special mobile. containers for disposal at a remote location. ${ }^{11}$

\subsubsection{Pressure-Suppression Containment with Secondary Containment}

Pressure-suppression containment shells are divided into two compartments. The reactor and most of the primary coolant system are enclosed in 
a pressure shell shaped like a light bulb with the base upward. This shell, conventionally referred to as the drywell, is designed to withstand a pressure of about $60^{\circ} \mathrm{psig}$ from flashing of the primary coolant. The drywell is surrounded by a toroidal (doughnut-shaped) suppression chamber with its horizontal center line a little below the bottom of the drywell. The suppression chamber, often called the wetwell or the torus, is about half full of water, is subject to lower postulated accident pressures, and is designed to withstand a pressure of about 35 psig.

The drywell is connected to the suppression chamber by large vent pipes that discharge 3 or $4 \mathrm{ft}$ under the surface of the water. In case of a rupture of the primary system in the drywell, the flashing coolant is released underwater in the suppression pool and is almost immediately condensed. The water in the suppression chamber thus serves as a heat sink for the almost immediate absorption of most of the energy in the released primary coolant. In addition the pool may absorb a large fraction of the fission products that might be transferred to the suppression chamber with the flashing primary coolant water.

Pressure suppression has been applied exclusively to direct-cycle boiling-water reactors. In these systems, an integral part of the containment concept is quick-acting isolation valves on the primary steam line to the turbine and the condensate return line, which extend the primary cooling system outside the drywell.

The maximum acceptable design-basis-accident leakage rate for the drywell and the pressure-suppression chamber is usually 0.5 wt \% of the contained volume per $24 \mathrm{hr} .^{6}$. This is five times the corresponding leakage rate for the pressure containment of pressurized-water reactors, but the volume of leakage enters a secondary containment structure (the refueling building), from which it is exhausted through a high-efficiency aircleaning system. In the $1727-\mathrm{MW}(\mathrm{th})$ Millstone Point reactor, ${ }^{2}$ a typical pressure-suppression system, the drywell has 128,000 $\mathrm{ft}^{3}$ of free volume and the pressure-suppression chamber has 110,000 $\mathrm{ft}^{3}$ of free volume and 94,000 $\mathrm{ft}^{3}$ of water, for a total containment volume of $332,000 \mathrm{ft}^{3}$. This can be compared with the 2,232,000 $\mathrm{ft}^{3}$ of free volume in the pressure containment 
vessel of the $1473-\mathrm{MW}_{\mathrm{W}}(\mathrm{th})$ Connecticut Yankee reactor, ${ }^{3}$ which has pressure containment.

Pressure-suppression systems have a refueling building surrounding the containment shell, which acts as a secondary containment structure. Provision for removal of fission products from the atmosphere within this secondary containment building is essential. If a pipe ruptured in the part of the primary cooling system outside the containment shell, some primary coolant would leak into the secondary containment building. The isolation valves would. close rapidly, but if the coolant contained fission products at the time of rupture, some would be discharged into the atmosphere within the secondary containment building.

Double pressure suppression has been proposed for metropolitan siting in one case..$^{13}$

\subsubsection{Proposed Ice Condenser Containment}

In a promising type of containment, developed by Westinghouse for pressurized-water reactors, ${ }^{14}$ an insulated blanket of millions of hollow cylinders of ice forms a massive heat sink around the inside of the containment shell. The system, known as the ice condenser reactor containment. system, has been extensively tested, including subjecting a fullscale segment to steam at accident temperature and pressure. The insulated ice is kept frozen by standard refrigeration equipment. In an accident, insulated panels would automatically spring open to provide a path for steam to reach the ice.

The system is reported to be capable of reducing the pressure to normal in a few minutes. In one Westinghouse test ${ }^{4}$ the steam pressure was reduced to a safe level in $30 \mathrm{sec}$, and not over 2-psig pressure was built up in the containment shell. In the ice condenser containment design, the design pressure requirement is reduced from about 45 psig to about $10 \mathrm{psig}$, and containment shell volume is reduced by half.

\subsection{Containment Shell Cooling Sys.tems}

Where recirculating air-cleaning systems are used as engineered safety features within the containment shells of current water-cooled 
power reactors, these systems have, in almost all cases, been provided by the addition of HEPA filters and charcoal adsorbers (usually preceded by moisture deentrainers and prefilters) to the recirculating containment atmosphere cooling systems. Removal of iodine from containment atmospheres by addition of a chemical to the containment cooling sprays has been proposed for several new reactors. Because air cleaning within the containment shell is closely related to containment cooling systems, these systems are discussed briefly in this section.

Cooling of the atmosphere within the containment shell is necessary during normal operation of water-cooled power reactors and is a-vital engineered safety feature to prevent containment pressure from exceeding the design limit in the event of a postulated accident. Emergency corecooling systems ${ }^{15}$ are provided to remove postaccident decay heat, to minimize fuel melting and cladding rupture, and to thereby minimize the release of fission products from the core, the reaction of cladding metal with water, and the buildup of temperature and pressure within the containment shell. Containment atmosphere cooling systems are provided not only to minimize but also to reduce temperature and pressure in order to reduce leakage of fission products from the containment vessel.

\subsubsection{Cooling Coil Eyatemo}

During normal operation, cooling must be provided in the containment shell; otherwise, excessive temperatures (from.heat leakage from the reactor system) might damage electrical insulation and instruments. Operational cooling is normally provided by recirculating the containment atmosphere over water-cooled coils with a fan. Several parallel systems are usually provided. These systems can, of course, also function to remove heat after an accident. If the system is to be depended upon for this purpose, the fan and its motor must be designed for postaccident conditions (air-steam mixtures at 40 to $50 \mathrm{psig}$ and about $275^{\circ} \mathrm{F}$ ).

\subsubsection{Spray Cooling Systems}

Almost all water-cooled power reactors have provision for cooling the containment atmosphere in the event of a loss-of-coolant accident by 
spraying cold water directly into the containment shell. These sprays are normally supplied from a tank, pool, or pressure-suppression pool, with subsequent recycle of the water from the containment sump (or pressuresuppression pool), through coolers, and back to the spray header.

\subsection{Air-Cleaning Systems Predominating in Current Designs}

Two types of air-cleaning systems are widely included as engineered safety features in current water-cooled power reactors: once-through filter-adsorber systems in secondary containment exhaust lines and recirculating filter-adsorber systems within the containment shell. Both types have the same basic components: moisture deentrainers, prefilters, HEPA filters, and charcoal adsorbers.

\subsubsection{Once-Through Filter-Adsorber Systems in Secondary Contain- ment Exhaust Lines}

Once-through (single-pass) systems exhaust air from the secondary containment building or volume, through filters and adsorbers, to the outside atmosphere. The input flow consists of a large volume of leakage from the outside into the secondary containment building, which is maintained at a negative pressure by the air-cleaning system, and a small volume of leakage from the containment shell. The system therefore operates at essentially ambient conditions with a low fission product load. Some of the design characteristics of several secondary containment aircleaning systems are given in Table 3.1 and Fig. 3.1. Note in Fig. 3.1 that all these systems include HEPA filters, all except the system for the. early (1962 startup) Indian Point 1 reactor ${ }^{7}$ include charcoal adsorbers, and those for pressure-suppression plants include high-efficiency moisture deentrainers.

Most secondary containment structures on water-cooled power reactors are the refueling building surrounding pressure-suppression containment system. The air-cleaning system for the penetration rooms attached to the pressure containment shells of the oconee reactors ${ }^{9}$ is shown in Fig. 3.2. 
Table 3.1. Once-Tinrough Air-Cleaning. Sys Jems in the Secondary Containment Exhaust Lines of Pressure Containment Systems for PWR's and Pressure-Suppression Containment Systems for BWR's

\begin{tabular}{|c|c|c|c|c|c|c|}
\hline . & Designer & $\begin{array}{l}\text { Electrical } \\
\text { Power } \\
\text { Mw) }\end{array}$ & $\begin{array}{l}\text { Completion } \\
\text { Date }\end{array}$ & $\begin{array}{l}\text { Design Contain- } \\
\text { ment Shell } \\
\text { Leakage Rate } \\
\text { (cfm) }\end{array}$ & $\begin{array}{l}\text { Flow Through } \\
\text { Air-Cleaning } \\
\text { System } \\
\text { (cfm) }\end{array}$ & Reference \\
\hline \multicolumn{7}{|l|}{$\begin{array}{l}\text { Pressure containment } \\
\text { system }\end{array}$} \\
\hline $\begin{array}{l}\text { Indian Point } 1 \\
\text { Oconee } 1 \text { and } 2\end{array}$ & $\begin{array}{l}\text { Babcock \& Wilcox } \\
\text { Babcock \& Wilcox }\end{array}$ & $\begin{array}{l}255 \\
250 \text { each }\end{array}$ & $\begin{array}{l}1962 \\
1971-72\end{array}$ & 7.1 & $2000^{a}$ & $\begin{array}{l}7 \\
9\end{array}$ \\
\hline $\begin{array}{l}\text { Pressure-suppression } \\
\text { containment system }\end{array}$ & & - & & & & \\
\hline $\begin{array}{l}\text { Oyster Creek } \\
\text { Millstone Point } \\
\text { Dresden } 3 \\
\text { Browns Ferry } 1 \\
\text { and } 2\end{array}$ & $\begin{array}{l}\text { General Electric } \\
\text { General Electric } \\
\text { General Electric } \\
\text { General Electric }\end{array}$ & $\begin{array}{r}640 \\
650 \\
809 \\
-075 \text { each }\end{array}$ & $\begin{array}{l}1967 \\
1969 \\
1969 \\
1970-71\end{array}$ & $\begin{array}{l}1 \\
0.82 \\
1 \\
0.97\end{array}$ & $\begin{array}{l}2000^{a} \\
2000^{a} \\
4000^{a}\end{array}$ & $\begin{array}{l}16 \\
12 \\
17 \\
18\end{array}$ \\
\hline
\end{tabular}

ane spare system is provided. 
Indian Point I

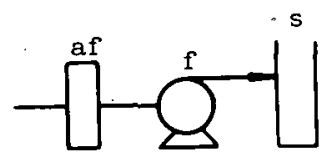

Dconee 1 and 2

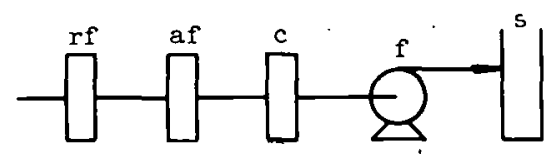

Millstone Point

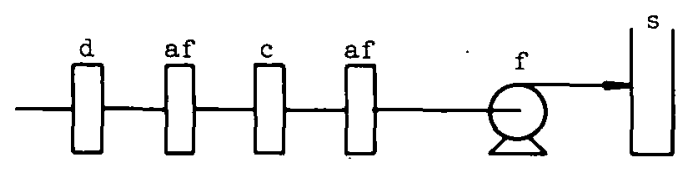

Browns Ferry 1 and 2

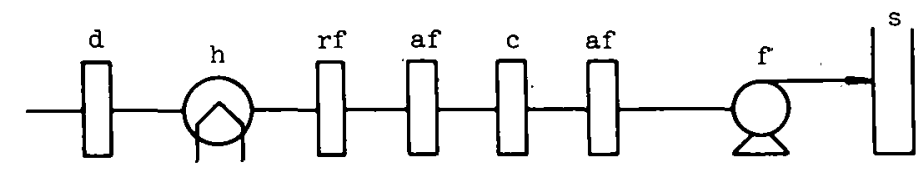

Fig. 3.1. 'l'ypical Componcnt Arrangements for Once-Through Air Cleaning Systems in Secondary Containment Exhaust Lines ( $d$ = high-efficiency moisture deentrainer; af $=\mathrm{HEPA}$ filter; $c=$ charcoal adsorber; $r f=$ roughing filter or prefilter; $f=f a n ; s=$ stack; $h=$ heater ).

\subsubsection{Recirculating Aix Filter-Adsorber. Systems Within the Corliainment Shell}

Moisture deentrainers, prefilters, HEPA filters, and charcoal adsorbers are sometimes adhed to the recirculating air-cooling system in the containment shell: Because of possible charcoal degradation from contaminants, the charcoal beds (and sometimes other components in the system) are usually bypassed during normal operation. In an emergency, dampers are switched to direct the air flow through the charcoal. These systems must be designed to withstand the temperatures and pressures resulting from a loss-of-coolant accident and must be protected against possible missiles.

Some of the design characteristics of typical installations are shown in Table 3.2 and Fig. 3.3. Note that recirculating air-cleaning systems 


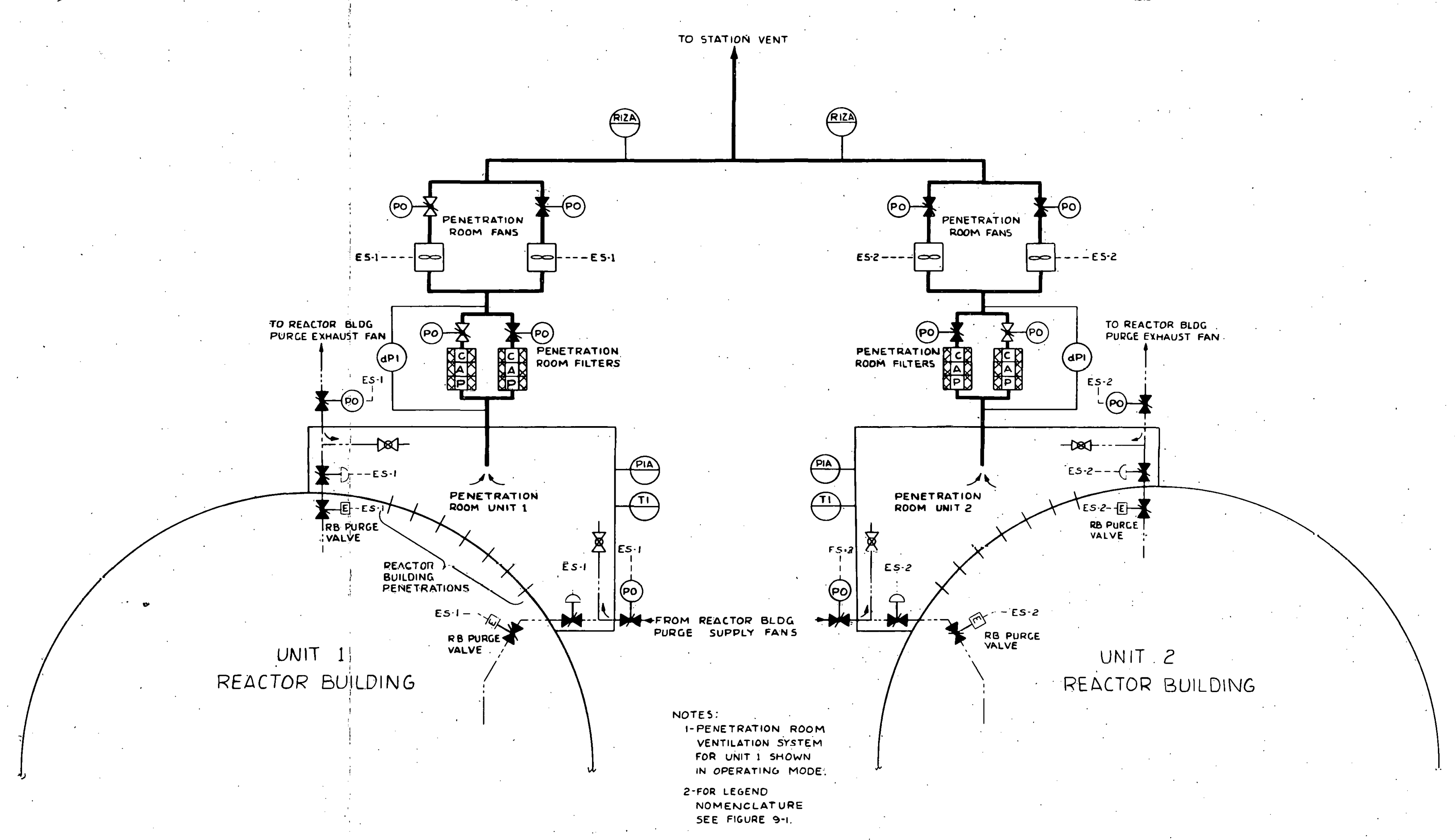

Fig. 3.2. Ventilation System for Penetration Room of Oconee Nuclear station Reactor. Building. The penetration room filters are designated $C$ for charcoal adsorber, A for HEPA filter, and $\mathrm{P}$ for prefilter. (From Ref. 9) 
Table 3.2. Recirculating Air-Cleaning Systems Within the Containment Shells of Pressure Containment Systems for PWR's

\begin{tabular}{|c|c|c|c|c|c|c|}
\hline Reactor ${ }^{a}$ & $\begin{array}{c}\text { Electrical } \\
\text { Power } \\
\left(\mathrm{Mw}^{\prime}\right)\end{array}$ & $\begin{array}{c}\text { Completion } \\
\text { Date }\end{array}$ & $\begin{array}{l}\text { Air Changes } \\
\text { per Hour }\end{array}$ & $\begin{array}{l}\text { Parallel } \\
\text { Systems }\end{array}$ & $\begin{array}{l}\text { Flow per } \\
\text { System } \\
(\mathrm{cfm})\end{array}$ & Reference \\
\hline Yarıkee & 175 & 1960 & 0.77 & 3 & 4,000 & 3 \\
\hline San Onofre & 428 & 1966 & \multicolumn{3}{|c|}{ (Hazards report not explicit) } & 19 \\
\hline Connecticus Yankee & 562 & 1967 & $5 \cdot 37$ & 4 & 50,000 & 20 \\
\hline Ginna & 470 & 1969 & 9.3 & 4 & 38,000 & 21 \\
\hline Indian Point 2 & 1033 & 1969 & 7.4 & 5 & 65,000 & . \\
\hline H. B. Robizson 2 & $\sim 750$ & 1970 & 11.4 & .4 & 100,000 & 22 \\
\hline Diablo Canyon & 1060 & 1971 & 7.5 & 5 & 65,000 & 23 \\
\hline
\end{tabular}

Westinghouse Electric Jorporation was the designer of these reactors. 
Yankee

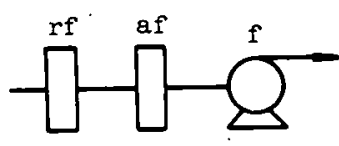

Connecticut Yankee

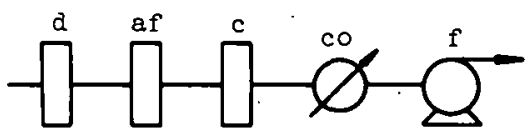

Ginna

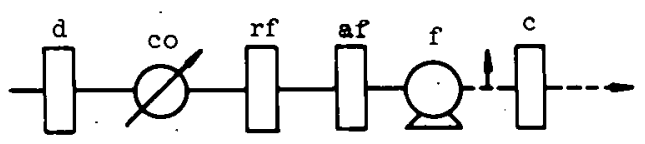

Indian Point 2

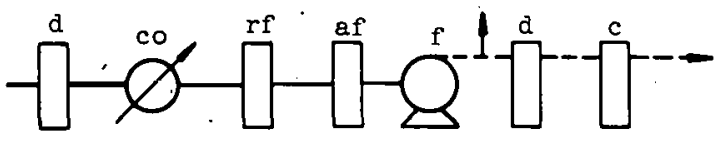

H. B. Robinson

2

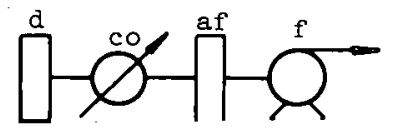

Diablo Canyon

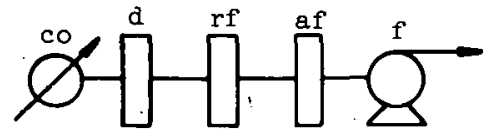

Fig. 3.3. Typical Component Arrangements for Recirculating Air-Cleaning Systems Within Containment Shells ( $d$ = high-efficiency moisture deentrainer; $\mathrm{rf}=$ roughing filter or prefilter; af = HEPA filter; $c$ = charcoal adsorber; $c o=$ cooler; $f=$ fan; solid lines indicate normal flow; dashed lines indicate accident flow).

are shown only for reactors with pressure containment (secondary containment air-cleaning systems for several pressure-suppression plants are shown in Table 3.1). All the recirculating air-cleaning systems shown are combined with containment cooling-coil systems. As shown in Fig. 3.3, all these systems contain HEPA filters, all except the system for the early 
(1960 startup) Yankee reactor ${ }^{3}$ include high-efficiency, moisture deentrainers, most contain prefilters, and charcoal adsorbers are usually bypassed during normal flow.

\subsection{New Applications and Proposed Air-Cleaning Systems}

\subsubsection{Once-Through Systems in Containment Shell Exhaust Iines}

Although recirculating filter-adsorber systems within the containment shell predominate in current pressure containment designs, cleanup of air exhausted directly from the containment shell by once-through highefficiency filter systems has been proposed for at least two installations, Turkey Point 3 and 4 (Ref. 4) and Malibu. ${ }^{10}$

Turkey Point 3 and 4 [760 Mw(e) each; 1971-72 startup] have pressurized-water reactors with pressure containment shells. In the event of a loss-of-coolant accident, the containment atmosphere would be cleaned to some extent by moisture deentrainers and prefilters in recirculating containment-air-cooling systems. After the postaccident pressure had been reduced, the containment air could be slowly purged through highet'ticiency filters and then released to the stack. ${ }^{24}$

In the Malibu system (described in Sect. 3.1.3), after a postulated accident, air leakage into the annulus between the two pressure containment shells would be pumped back into the inner shell to provide maximum containment. If it were necessary to vent the inner shell to the outside atmosphere for reduction of pressure buildup or for postaccident cleanup, air would be slowly purged from within the inner shell, through filters, and exhausted through the stack. Figure 3.4 is a schematic diagram of the aircleaning system for the double containment system once proposed for the Ravenswood reactor, ${ }^{25}$ which is essentially the same design. Note the variable-to-large flow under, normal conditions and the small flow through the purge system. (Concrete thicknesses in relation to the size of the containment shells have been greatly exaggerated in the diagram in order to show the porous concrete and the valves within the annulus.) 


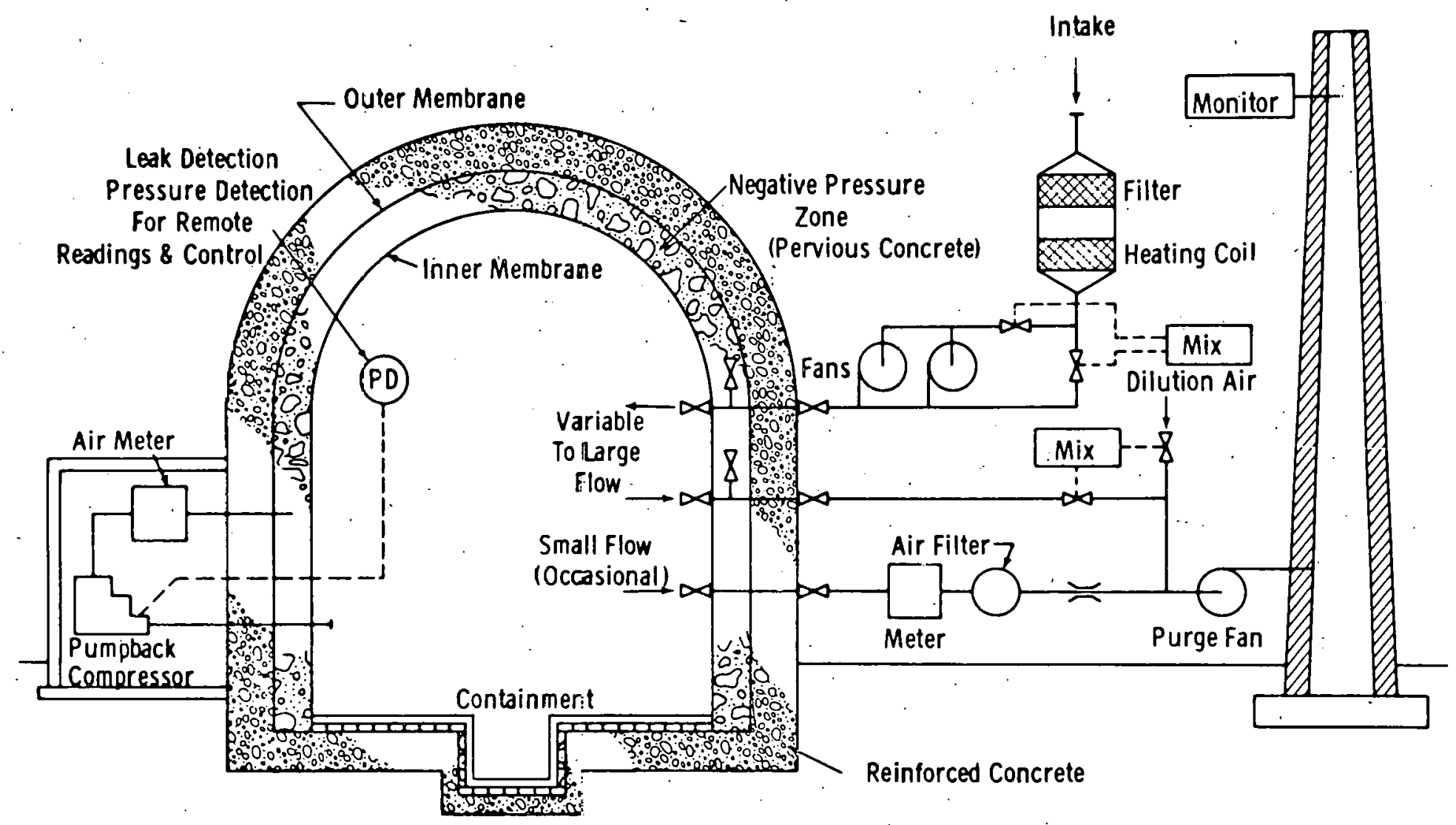

Fig. 3.4. Schematic Diagram of Air-Cleaning System for Proposed Double Containment Concept. (From Ref. 25) 
3.4.2 Chemical Spray Systems and Pressure-Suppression Pools

To insure that recirculating filter-adsorber systems will perform reliably and adequately in the removal of fission products under postaccident conditions, these systems must be protected from pressure surges, possible missiles, and the high pressures, temperatures, and humidities that would exist within the containment shell after a postulated loss-of-coolant accident. Such protection is very expensive. In an effort to develop a system that would be less expensive and yet reliable and adequate for postaccident fission-product removal within the containment shell, much attention has been directed to examination of the adaptability of containment atmosphere cooling sprays and pressure-suppression pools for fission-product removal. Chemical additives to react with iodine and methyl iodide are under investigation, and the addition of sodium thiosulfate to the water in the containment atmosphere spray cooling system has been proposed for at least four reactors with pressure containment systems (Indian Point 2, Ref. 5; Palisades, Ref. 26; H. B. Robinson 2, Ref. 22; and Diablo Canyon, Ref. 23). A schematic diagram of the Indian Point 2 safety injection system, which includes the containment spray system, is shown in Fig. 3.5. Note that the reactor containment spray header and nozzles (left center) within the containment shell are fed by the containment spray pumps (near the right in the diagram). The sodium thiosulfate is to be stored as a $30 \%$ solution in an addition tank. When the sprays are activated, valves will open and a sillall bypass flow will be directed from the spray pump discharge through the sodium thiosulfate tank and back to the pump suction. In this manner sodium thiosulfate will be introduced up to a final concentration of 2 wt $\%$ by meuris of a sealed (nonvented) system that provides for minimum possibility of fission-product leakage on recycle through the system.

If chemical sprays are shown to be effective, reliable, and practicable engineered safety features, they may be included in the designs of future water-cooled power reactors and perhaps added to some existing ones. Flow diagrams for typical pressure containment and pressure-suppression containmerit systems are shown in Figs. 3.6 and 3.7. The pumps, coolers, and most of the valives are usually located outside the containment shell, where they are less subject to possible accident damage and more accessible 


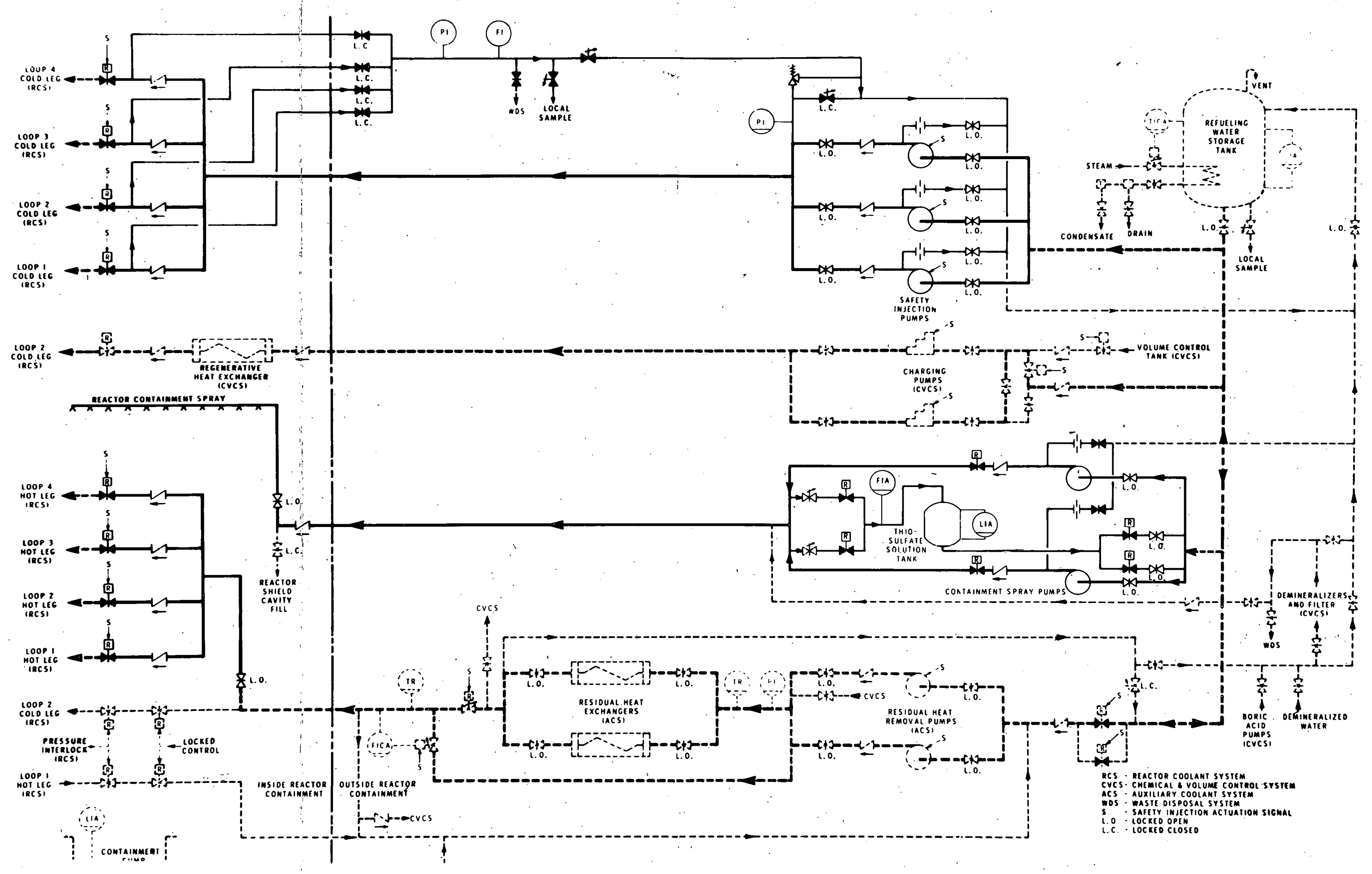

Fig. 3.5. Safety Injection System for Indian Point 2. (From Ref. 5) 


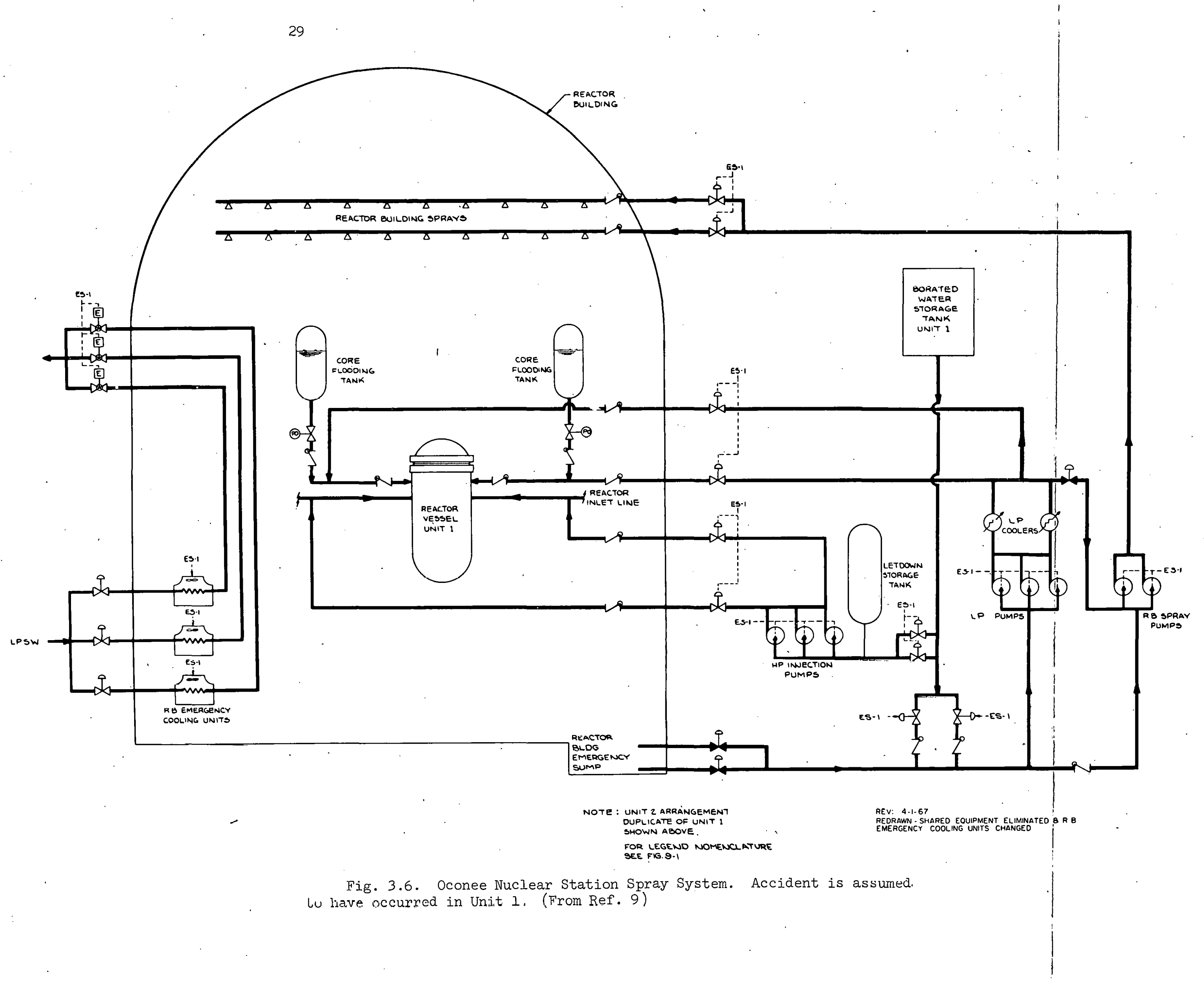




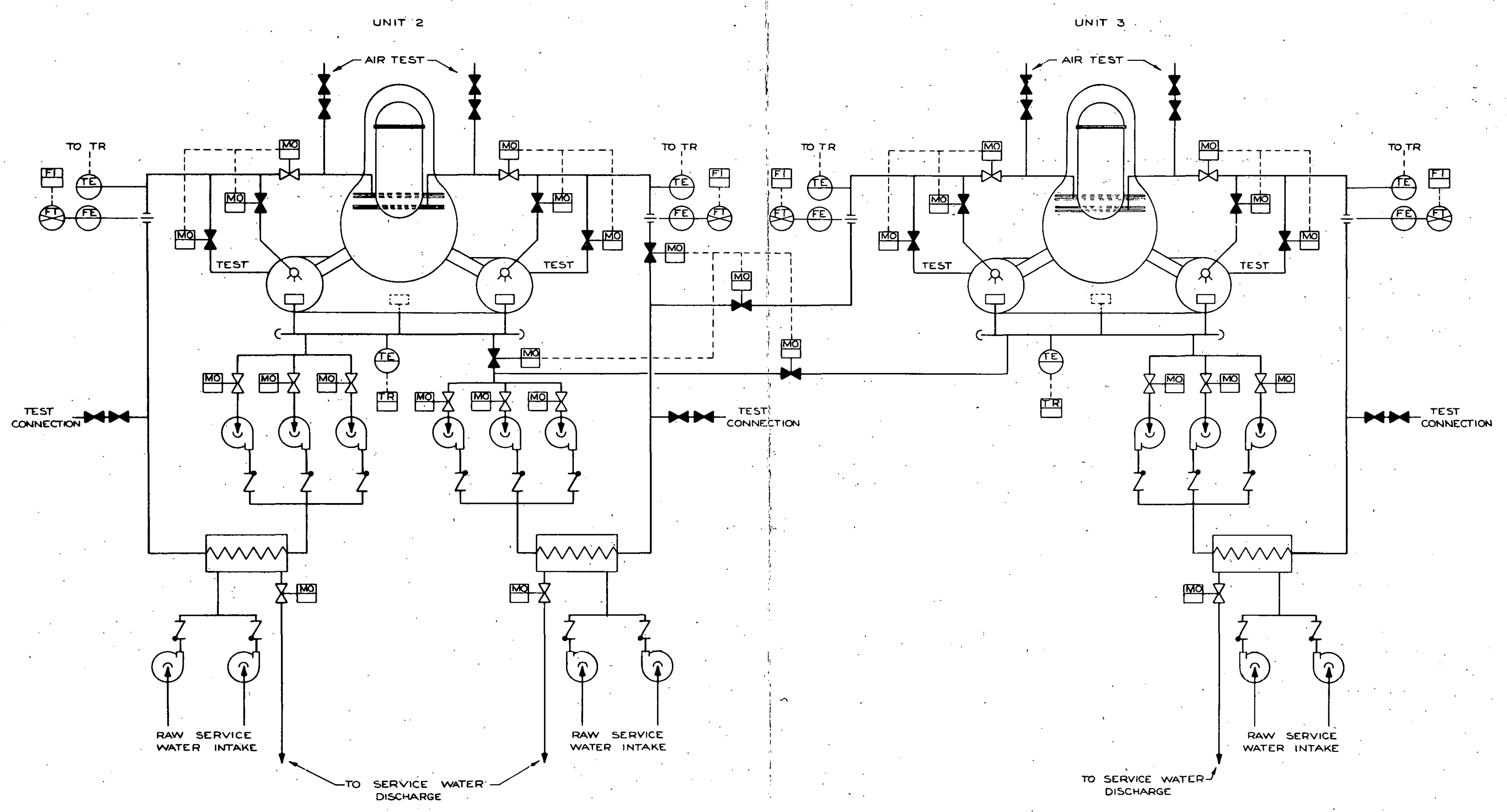

Fig. 3.7. Pressure Suppression Containment Spray System for Dresden

3. (From Ref. 1.7) 
for maintenance and testing (they must be shielded and there must be a positive means of containing leakage). The pumps are normally tested with water through a recirculating loop up to an isolation valve; beyond the valve the system is tested with air to be sure that the spray nozzles are not plugged. Entire spray systems cannot be operationally tested without taking extraordinary measures to protect nonwaterproofed electrical and other equipment in the containment shell. (In some plants, such equipment is already designed with protection for necessary operation under wet accident conditions; such plants may be amenable to occasional spray testing with plain water).

\section{$\underline{\text { References }}$}

1. General Electric Company, Preliminary Hazards Summary Report for the Dresden Nuclear Power Station, USAEC Report GEAP-3076, Dec. 29, 1958.

2. Consumers Power Company, Final Hazards Summary Report for Big Rock Point Plant, Docket 50-155, Nov. 14, 1961.

3. Yankee Atomic Electric Company, Yankee Nuclear Power Station Final Hazards Summary Report, Docket 50-29, Vol. 1, June 1962.

4. Florida Light and Power Company, Turkey Point Nuclear Generating Units 3 and 4, Preliminary Safety Analysis Report, Dockets 50-250 and -251.

5. Consolidated Edison of New York, Inc., Indian Point Nuclear Generating Unit No. 2, Preliminary Safety Analysis Report, Docket 50-247.

6. F. C. Zapp, Testing of Contaịment Systems Used with Light-WaterCooled Power Reactors, USAEC Report ORNL-NSIC-26, Oak Ridge National Laboratory (to be published):

7. Report on Hazards Analysis and Design for Containment Vessel of Consolidated Edison Thorium Reactor, Exhibit K-4, Docket 50-3, Appendix A, August 1958 .

8. W. B. Cottrell, Chap. 1, Introduction, p. 1.50 in U. S. Reactor Containment Technology, USAEC Report ORNL-NSIC-5, W. B. Cottrell and A. W. Savolainen, Eds., Oak Ridge National Laboratory, August 1965.

9. Duke Power Company, Oconee Nuclear Station Units 1 and 2, Preliminary Safety Analysis Report, Dockets 50-269 and -270. 
10. Department of Water and Power, City of Los Angeles, Preliminary Hazards Summary Report for Malibu Nuclear Plant Unit No. I, Docket 50-214, November 1963.

11. H. B. Piper, Chap. 7, Descriptions of Specific Containment Systems, p. 7.134 in U. S. Reactor Containment Technology, USAEC Report ORNLNSIC-5, W. B. Cottrell and A. W. Savolainen, Eds., Oak Ridge National Laboratory, August 1965.

12. The Connecticut Light and Power Company, The Hartford Electric Light Company, and Western Massachusetts Electric Company, Design and Analysis Report for Millstone Nuclear Power Station, Docket 50-245.

13. Boston's Nuclear Plant has Siting Problems, Nucl. News, 9(6): 12 (June 1966).

14. Nuclear Safety with Ice Cubes, Power Engineering, November 1967; also, an article by W. F. Davis is to be published in Nucl. Safety, Vol. 9, No. 5 (September-October 1968).

15. C. G. Lawson, Emergency Core-Cooling Systems for Light-Water-Cooled Power Reactors, USAEC Report ORNL-NSIC-24, Oak Ridge National Laboratory (to be published).

16. Jersey Central Power and Light Company, Facility Description and Safety Analysis Report for Oyster Creek Nuclear Power Plant Unit No. 1, Docket 50-219.

17. Commonwealth Edison Company, The Dresden Nuclear Power Station Unit No. 3, Preliminary Design and Analysis Report, Vol. 2, Docket 50249, February 1966.

18. Tennessee Valley Authority, Design and Analysis Report for Browns Ferry Nuclear Power Station, Dockets 50-259 and -260.

19. Southern California Edison Company and San Diego Gas and Electric Company, Final Engineering Report and Safety Analysis for San Onofre Nuclear Generating Station Unit 1, Docket 50-206.

20. Connecticut Yankee Atomic Power Company, Facility Description and Safety Analysis for Haddon Neck Plant, Topical Report No. NYO-3250-5, Docket $50-213$.

21. Rochester Gas and Electric Corporation, Preliminary Facility Description and Safety Analysis Report for Brookwood Nuclear Station Unit No. 1, Docket 50-244.

22. Carolina Power and Light Company, Preliminary Facility Description and Safety Analysis Report for H. B. Robinson Unit No. 2, Docket 50261 . 
23. Pacific Gas and Electric Company, Preliminary Safety Analysis Report for Nuclear Plant, Diablo Canyon Site, Docket 50-275.

24. G. W. Keilholtz, Air Cléeaning Systems as Engineered Safeguards in Nuclear Reactor Containment, Nucl. Safety, 8(4): 360-370 (1967).

25. Preliminary Hazards Summary Report of Consolidated Edison Company of New York, Inc:, Ravenswood Nuclear Generating Unit A, 1963, USAEC Report NP-12467, Technical Information Service Extension, 1962.

26. Consumers Power Company, Facility Description and Safety Analysis Report for Palisades Plant, Docket 50-255. 


\section{PERFORMANCE AND TESTING OF HEPA FILTERS}

The efficiency of new HEPA filter units for the removal of the standard test aerosol recommended by the USAEC is specified as not less than $99.97 \%$ under the standard test conditions. Where it can be assured that filter media, separators, gaskets, seals, frames, and other components in a filter system will be intact and will not have significantly deteriorated up to the time of a postulated accident, and where it can be assured that during and after the accident the system would prevent damage to the filters and would adequately pretreat the air before it reached the filters, confidence in the efficiency of HEPA filters during postaccident operation will be very high.

In practice, however, filter integrity and optimum postaccident operating conditions for HEPA filters are difficult to insure. Damage to filter media during handling, improper installation, deterioration of media, separators, and seals, and excessive leakage that bypasses the filters are not always detected and corrected by inspection, testing, and maintenance. Housings, ducts, dampers, and other filter system components are often not designed, fabricated, installed, inspected, and maintained in a manner that guarantees postaccident system integrity and protection of the filters. Moisture removal devices in some systems are not capable of insuring that the humidity of the air that reached the filters after an. accident would be low enough for optimum filter efficiency.

A manual entitled "Design and Construction of High-Efficiency AirFiltration Systems" is being prepared at ORNL by C. A. Burchsted and A. B. Fuller as a guide for designers of air-cleaning systems for nuclear applications. The manual is written primarily with operating, maintenance, and hazards control in mind and attempts to answer the question: "What from the standpoint of mechanical design is required for a reliable, economic system?" Problem areas or factors that often compromise operations are identified, and mechanical, structural, and layout requirements are discussed in detail, as well as the performance and limitations of major system components. Reliability and total cost, rather than first cost, are stressed. There is also a separate chapter on the special problems 
of remotely maintained and nuclear reactor postaccident cleanup filter systems.

Drafts of the manual have been reviewed in detail by users and hazards control personnel of the major AEC contractors and are being reviewed at AEC Headquarters. The comments received will be considered in the final issue as an AEC-TID handbook.

Each HEPA filter must be tested and inspected before installation and must be packaged, shipped, handled, and installed with care. HEPA filters must be routinely tested in $\mathrm{place}$ as part of the filter system, and individually when necessary, throughout their service life. Also, system leakage that bypasses air around the filters must be very low. HEPA filter systems must be designed, tested, inspected, and maintained so that the conditions under which the filters themselves operate are good. The filters must be protected from shock waves, pressure surges, high pressure differentials, excessive moisture and particulate loadings, and fire.

\subsection{Efficiency and Testing}

There has been continuing interest in determining, as accurately as possibie, the ability of HEPA filters to remove real accident-produced aerosols under real postaccident conditions. Also, the increasing number of water-cooled power reactors and the trend toward urban siting have brought increased emphasis on the establishment of routine efficiency tests that will accurately predict postaccident filter efficiency. For research purposes this problem has been divided into a number of questions. Can the efficiency of HEPA filters for the rcmoval of the standard test aerosol under standard test conditions be adequately correlated with efficiency for the removal of aerosols under simulated postaccident conditions? How accurately does the filtration of simulated accident-produced aerosols under simulated postaccident conditions represent the filtration of real accident-produced aerosols under real postaccident conditions? Do we need a new test aerosol for testing HEPA filters that are to be depended on as components of engineered safety features? Do we need to test with simulated accident-produced aerosols? Do we need more realistic test humidities, tcmpcratures, flow rates, and pressure differentials? Are the 
dioctyl phthalate (DOP) aerosol and test conditions now used for routine testing applicable to the accurate prediction of postaccident filter efficiency?

These questions have been partially resolved., Testing of new HEPA filter units with the standard DOP test (in-place testing of filter systems is discussed in Chapter 6) and the effects of moisture and flow rate on the efficiency of HEPA filters for the removal. of simulated accident-produced aerosols containing fission products, as well as fuel and cladding materials, are described in the following subsections.

International agreement on a standard efficiency test for filters has not yet been reached. In each of several countries in which HEPA or similar filters are widely used, authorities on filter-efficiency testing feel that their standard method has advantages over the others. For example, British standards specify tests wi.th particles of sodium chloride or methylene blue, ${ }^{2}$ and the Dust Research Institute in Bonn, West Germany, uses a combination test with three kinds of solid and liquid particles. ${ }^{3}$ Much of the world, however, seems to be adopting the test with monodisperse 0.3- $\mu$ dioctyl phthalate, which is standard in the United States. ${ }^{4}$

\subsubsection{Preinstallation Efficiency Testing of HEPA Filter Units}

In the United States the effioicncy of new HEPA fllters tor reactor installations is determined with thermally generated dioctyl phthalate (DOP) of $0.3-\mu$ particle diameter, by the manufacturer, following Edgewood Arsenal procedures." In addition, as mentioned above, there are two USAEC Quality Assurance Stations (filter testing facilities) for verifying the efficiency of new filters by following the same test procedures. This service is available on request or when specified by the purchaser. ${ }^{5}$

The filter to be tested is installed in a duct, flowing air and the test aerosol are introduced upstream, and the concentrations of the aerosol in air samples from the duct upstream and downstream of the filter are measured. Efficiency is calculated by dividing the downstream concentration by the upstream concentration, which gives the penetration as a decimal fraction; multiplying by 100 to convert to percentage; and subtracting the percentage penetration from 100 to give the percentage removed by the filter, which is conventionally referred to as efficiency. 
- Delivery of HEPA filter units should not be accepted by USAEC offices, contractors, or licensees until each unit has been inspected and tested by one of the two USAEC Quality Assurance Service filter testing facilities. Each filter is required to meet the specification of $99.97 \%$ for the removal

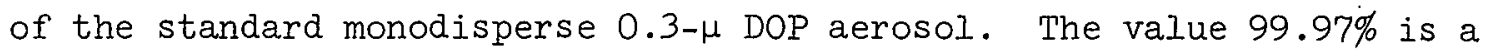
reasonable compromise between necessary manufacturing tolerance and protection for the user. Most HEPA filters test at substantially higher values. ${ }^{6}$ HEPA filters are delicate and should be shipped, handled, and installed with care.

Testing at two flow rates, 100 and $20 \%$ of rated flow, is recommended by the AEC to disclose pinholes and leaks that cannot be found by testing at rated flow alone or by visual inspection.7 Two-flow testing is based on the pinhole effect. ${ }^{8}$ According to theoretical analyses ${ }^{9}, 10$ of this effect, airflow through the intact part of the filter is essentially streamline, and the flow rate is directly proportional to pressure drop. Airflow through the pinhole (or other small defect) is turbulent, and the flow rate is proportional to the square root of pressure drop. Therefore, with an increase in overall air flow through filters containing such defects, and a corresponding increase in pressure drop, proportionately less air passes through the defect. The net effect is an increase in filtration efficiency with increasing flow rate. The pinhole effect would not apply, of course, in cases where the size of the leakage path increased with increasing flow.

Whatever the actual mechanism, the pinhole effect is well established experimentally. ${ }^{8-12}$ A statistical analysis of filter test results showed a $95 \%$ probability of significant pinholing if the difference in penetration between the full-flow test and a $20 \%$ flow test exceeded $0.01 \% .{ }^{13}$ This is borne out by other work. ${ }^{14,15}$ It has been recommended ${ }^{16}$ that specifications for the procurement of HEPA filters include a requirement for two-flow testing, at rated flow and at $20 \%$ of rated flow, with a maximum permissible penetration difference of $0.01 \%$ between the two flows for 500-cfm and larger filter units. Testing of smaller units at $20 \%$ of rated flow is not considered practical because of questionable results at the low flow velocities. 


\subsubsection{Efficiency of HEPA Filter Media Under Simulated Post- accident Conditions}

After a postulated loss-of-coolant accident. in a light-water power reactor; the HEPA filters in the air-cleaning systems might be subjected to an aerosol composed largely of oxides of uranium and cladding (Zircaloy or stainless steel) produced by overheating of reactor. fuel. Also, the atmosphere introduced into a recirculating air-cleaning system within the containment structure would be saturated with water at a relatively high temperature (about $275^{\circ} \mathrm{F}$ ). In the highly unlikely event of a breach in the containment system, a once-through air-cleaning system in the exhaust of a secondary containment structure would be subjected to a hot, very humid atmosphere. The polydisperse, largely solid aerosol and the wet high-temperature postaccident atmosphere would be quite different from the monodisperse liquid DOP and the dry air at ambient temperature with which new filter units are generally tested.

In a continuing program at ORIVL, the characteristics, agglomeration, filtration, and settling of realistic oxide aerosols are being studied under simulated accident conditions. As part of this program, the efficiencies of a number of commercially available HEPA filter media for. aerosols of the type expected from the melting of light-water-cooled power reactor fuels are being measured as a function of velocity and humidity of the air and the amount of water in the filter media.17-19 The aerosols are oxides of stainless steel and uranium generated from $\mathrm{UO}_{2}$ and stainless steel by an electric arc. These are laboratory-scale studies on assemblies of three 1.5-in.-diam disks of HEPA filter media mounted in series. Full-size HEPA filter units have not been tested, and the test loop does not contain moisture-removal devices upstream of the disks of filter media.

Eight HEPA filter media have been tested in this study. Six of these are waterproofed: Flanders 700, Flanders 800, AAF type A57, AAFI, MSA UltraHEPA, and Cambridge 115EWP. Two of the media tested are nonwaterproofed: Flanders 600 and Cambridge l.15E. At $5 \mathrm{ft} / \mathrm{min}$ (the approximate linear velocity equivalent to the rated volumetric test flow for DOP testing) at room temperature in a dry atmosphere (about $2 \%$ relative humidity), the measured efficiency of the Flanders 700 media for the aerosol of. 
stainless steel and uranium oxides was $99.97 \%$, with an average deviation of $\pm 0.01 \%$ in 15 measurements. In a water-saturated atmosphere at $5 \mathrm{ft} / \mathrm{min}$, the two nonwaterproofed HEPA media had efficiencies of 99.84 and $99.80 \%$; also, two of the waterproofed media, Cambridge ll5EWP and AAFl, were significantly less efficient ( 99.93 and $99.92 \%$ ) than the others tested. The efficiencies of the other four media were between 99.97 and $99.98 \%$. Each of these efficiencies under humid conditions is an average of three or four measurements.

Tests of these eight HEPA media in a water-saturated atmosphere were also run at $3.5,7.5$, and $10 \mathrm{ft} / \mathrm{min}$. The results of these tests are shown in Fig. 4.1. The efficiencies for the test aerosol at 3.5 and $7.5 \mathrm{ft} / \mathrm{min}$ were not very different from their efficiencies at $5 \mathrm{ft} / \mathrm{min}$, but their efficiencies at $10 \mathrm{ft} / \mathrm{min}$ were significantly lower.

In the same study, the effects of long-term exposure of HEPA filter media to water-saturated atmospheres before testing and of accelerated short-term exposure to water-saturated atmospheres or to water before testing were investigated. Two of the waterproofed media, Flanders 800 and MSA UltraHEPA, which had measured efficiencies of $99.97+\%$ for the test aerosol when dry, had average efficiencies of 99.79 and $99.91 \%$ after storage in 100\%-humidity air at room temperature for 12 to 13 days, average efficiencies of 99.31 and $99.46 \%$ after storage under the same conditions for 43 to 45 days, and efficiencies of 99.79 and $99.12 \%$ after storage in $100 \%$-humidity air at $80^{\circ} \mathrm{C}$ for 24 to $28 \mathrm{hr}$. Samples of one of the nonwaterpronfer medi.a, Flanders 600, had an average efficiency of $98.89 \%$ after one drop of water was put on each $1.5-\mathrm{cm}$ disk just before testing. Measurements of fiber diameter distributions on four of the eight HEFA filter. media showed two ranges of fiber diameter, one at about $\hat{\alpha} \mu$ and the other at about $0.15 \mu$. It was postulated that the deleterious effect of moisture on filtration efficiency may be caused by condensation of water on and between the 0.15- $\mu$ fibers and a consequent increase in apparent fiber diameter. This hypothesis was found by calculations to be reasonable in relation to filtration theory (see also Sect. 6.3.1, which discusses reduction of agglomerate size by high relative humidity). 


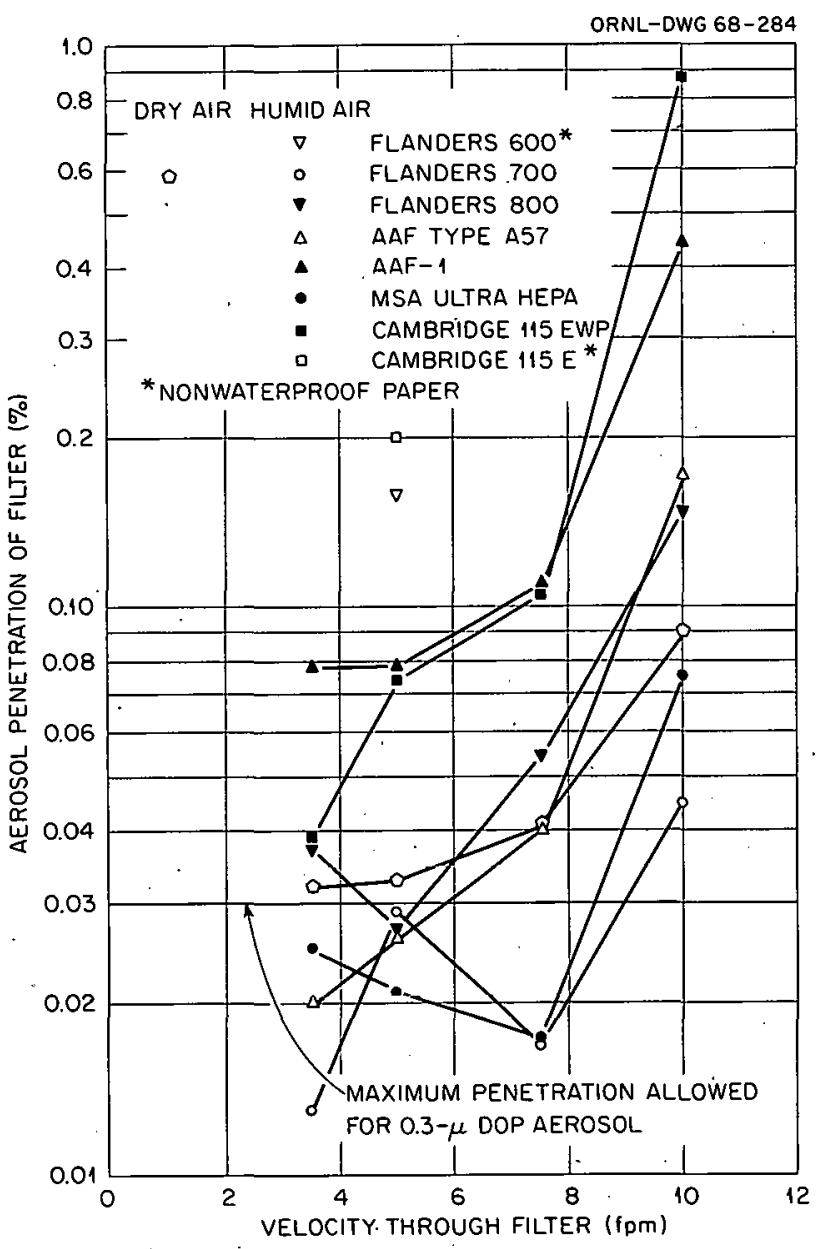

Fig. 4.1. Penetration of Fi, ter Media by Stainless Steel-UO 2 Aerosols Under Dry and Humid Conditions. (From Ref. 17)

\subsection{Filter Performance Under Operating Conditions}

\subsubsection{Protection of HEPA Filters from Moisture Damage}

High moisture loadings can damage HEPA filters, either by plugging or by deterioration of the filter media. Moisture deentrainers must be provided upstream of HEPA filters that are depended on to perform under wet postaccident conditions.

4.2.1.1 Tests of Moisture Deentrainers and HEPA Filters by the Savannah River Laboratory. Extensive tests have been made of the ability of moisture deentrainers to protect HEPA filters and activated charcoal beds after a postulated loss-of-coolant accident in the activity- 
confinement system of the Savannah River Plant reactors. Descriptions and. results of the tests, as well as specifications for moisture separators, water-repellent HEPA filters, and activated charcoal beds for use in the Savannah River Plant system, have been published. ${ }^{20-22}$

The filtration-adsorption system in the ventilation exhaust of each reactor building at the Savannah River Plant has five filter compartments, each of which contains a bank of moisture separators, a bank of HEPA iilters, and a bank of activated charcoal beds. The banks of HEPA filters, preceded by moisture separators, are designed to remove more than $99 \%$ of all airhorne radioactive particles $0.3 \mu$ in diameter and larger, even if the particles are carried in a fog stream after a loss-of-coolant accident. The moisture separators (York M321 Demisters), which are mats of DuPont Teflon yarn woven on stainless steel wire and wrapped with stainless steel reinforcing wire, are 2 ft $\times 2$ ft $x 2$ in. thick and rated for 1600-scfm air at $0.95 \mathrm{in.} \mathrm{H}_{2} \mathrm{O}$. The filters are 1000-cfm open-face steel-cased HEPA filters, $24 \times 24 \times 111 / 2$ in.

Tests at the Savannah River Laboratory showed that when moisture separators were provided, the HEPA filters successfully passed flows of wet. steam and fog mixtures for ten days, even when the filters contained normal dust equivalent to 18 months of exposure to flowing air. ${ }^{20}$ The tests simulated a power-surge accident that did not breach the reactor building, followed by evaporation of the coolant. In a simulation of failure to reestablish coolant flow, wet steam was emitted for $30 \mathrm{sec}^{\prime}$ at 7000 scfm per filter, and the subsequent, evaporation caused mixtures of steam, air, and entrained water to be evolved at rates up to 1 lb of water per minute per filter for 10 days. $^{21}$ In a typical test, partial plugging of the dusty filters by water particles that initially escaped the separator reduced the mixed flow to a minimum of $60 \%$ of the rated filter flow (1000-scfm air) $6 \mathrm{hr}$ after the test started; however, the flow gradually increased to over 900 scfm at the end of the test. The HEPA filters exceeded their efficiency requirement after the test. Filters tested without moisture separatórs upstream were almost completely plugged with liquid water, and some ruptured during the fog test. 
Tests of long-term exposure of moisture separator filter assemblies to flowing air containing normal dust are being continued to determine the service life of the filters. A service life of about two years is indicated for the particulate filters. An indefinite service life is indicated for the moisture separators, which are cleaned periodically (about once a year) with steam to restore flow and pressure-drop characteristics to values equal to those of new units. 20

4.2.1.2 Tests of a Proposed Moisture Separator for the Connecticut Yankee Atomic Power Plant. Tests were conducted by the Clean Air Group Research Laboratory, American Air Filter Company, for the Connecticut Yankee Atomic Power Company, to determine the effect of entrained water from containment atmosphere cooling sprays of a proposed moisture separator, which consisted of wave-plate steel baffles followed by three 2-in.thick fiber-glass pads, with a space of about 1 in. between the second and third pad. ${ }^{23}$ The test facility used was capable of circulating $1000 \mathrm{cfm}$ of saturated air-steam mixtures at as high as $40 \mathrm{psig}$ and $261^{\circ} \mathrm{F}$, the maximum predicted conditions. Water sprays simulated the droplet cloud expected. The moisture separator removed essentially all droplets from the air stream under six test conditions with pressures ranging from 10 to 40 psi. HEPA filters downstream of the separator (1000-cfm filters, tested one at a time) withstood test periods of up to $24 \mathrm{hr}$ at predicted maximum conditions without measurable loss of performance.

\subsubsection{Resistance to Fire and Hot Air}

A fire in a filter system can reduce or destroy the ability of the system to remove and contain radioactive materials. Filter systems provided as engineered safety features must be adequately protected against fire, and their components, including HEPA filters, must be fire resistant.

Fire-resistant HEPA filter units are qualified by Underwriters' Labo-. ratories for resistance to fire and hot air, in accordance with the Laboratories' standard UL-586. ${ }^{24}$ Among the qualification tests are a hot air test, in which air at $700 \pm 50^{\circ} \mathrm{F}$ is passed through the filter for 5 min at rated air flow, and a spot flame test, in which a $1750 \pm 50^{\circ} \mathrm{F}$ flame is directed against each of several points on the upstream face of the filter for $5 \mathrm{~min}$, also at rated air flow. The hot air test determines the effect 
of hot air on filter performance, and the spot flame test is a test of combustibility. ${ }^{16}$ Only UL-labeled filters should be used in reactor applications.

Unlike DOP efficiency tests and other nondestructive tests performed on all filter units when specified, these destructive qualification tests are performed only on sample filter units, not on units intended for actual use after testing. When samples have passed the tests, all units made by the manufacturer of the samples to the same specifications of design, materials, and construction are thereby qualified under UL-586, subject to spot checking by Underwriters' Laboratories of units from production runs.

The protection of installed HEPA filters and filter systems from fire is discussed in Chapter 6.

\subsubsection{Resistance to Shock Waves}

HEPA filters must be protected against shock waves from possible explosions. In order to design systems that wịll provide adequate protection, it is necessary to know the shock wave overpressure that would cause significant reduction in the efficiency of unprotected HEPA filters. of the size to be used and to know the overpressures that would cause more extensive damage.

In tests conducted by the Naval Research Laboratory and the Naval Ordnance Laboratory (NRL-NOL), HEPA filters of the sizes commonly used in the AEC program were subjected to shock waves that produced a range of overpressures. ${ }^{25}$ The purpose was to determine the shock overpressure that caused the efficiency of filters of each size to fall below the $99.97 \%$ specification and the overpressures at which various degrees of visible dastage occurred.

Small test charges were exploded in the chamber of a 6-in. gun. The . muzzle of the gun was fastened to one end of a tube 180 ft longin, which tapered wiformly from a diameter of 6 in. at. the gun muzzle to a diameter of 30 in. at the other end. Each filter to be tested was mounted in the center of a heavy steel plate that covered the 30-in. end of the tube. Since the total force of each explosion was directed toward the filter, the shock waves simulated those from the explosion of large, unconfined 
spherical charges about 200 ft from the filter. The most significant difference between the test shock waves and those from large spherical charges was that the positive duration (time for overpressure to decay from peak to zero) at the large end of the tube was about $50 \mathrm{msec}$ and was almost independent of charge size, whereas the positive duration of the shock wave from a spherical charge increases with charge size and would be longer (of the order of 100 to $200 \mathrm{msec}$ ) in a reactor accident.

The filters in the NRL-NOL tests were open-face rectangular fireresistant HEPA filters, and all were obtained from the same manufacturer. The media from which they were fabricated and the filter units were tested after fabrication to assure that they met all specifications, including the standard DOP efficiency test. Each filter was subjected to shock overpressures of increasing intensity and was inspected for visible damage after each exposure to a shock wave. If no visible damage was found, the DOP efficiency of the filter was measured.

Clean filters failed (DOP efficiency fell below. $99.9 \%$ ) at the shock overpressures tabulated below. (The thicknesses given are slightly modified to specification thicknesses; thicknesses given in Ref. 25 are rounded off to 3,6 , and $12 \mathrm{in.)}$

\begin{tabular}{ccc}
$\begin{array}{c}\text { Filter Size } \\
\text { (in.) }\end{array}$ & $\begin{array}{c}\text { Overpressure at Failure } \\
\text { (psi.) }\end{array}$ \\
\cline { 2 - 3 } $8 \times 8 \times 31 / 16$ & 3.6 \\
$8 \times 8 \times 57 / 8$ & 4.5 \\
$12 \times 12 \times 57 / 8$ & 3.6 \\
$24 \times 24 \times 57 / 8$ & 2.2 \\
$24 \times 24 \times 111 / 2$ & 3.2
\end{tabular}

The ability to withstand shock increased with decreasing face area for a given thickness and increased with increasing thickness for a given face area. Pressures near the failure pressures caused cracks in the adhesive or small leaks at the media-adhesive bond. Pressures 0.5 to 1 psi greater than the failure pressures caused blowout slits in the downstream folds of the pleats. Pressures more than 2 psi greater than failure pressures caused extensive damage, including very long cracks perpendicular to the 
pleats. Very high overpressures (over 5 psi greater than failure pressure) caused gross damage. In some cases essentially all media and separators were removed from the frame.

To determine the shock-wave resistance of filters nearing the end of their useful service life, a number of units were loaded with a test dust that had a number median diameter of about $0.5 \mu$ and a mass median diameter of about $1.8 \mu$. Each unit was loaded to a pressure drop of 4 in. $\mathrm{H}_{2} \mathrm{O}$ at rated flow. When tested with the dust-loaded side toward the explosive charge, an $8 \times 8 \times 57 / 8$-in. filter failed at 3.9-psi overpressure (compared with 4.5 psi for a clean filter) and a $24 \times 24 \times 11$ 1/2-in. filter failed at 2.9-psi overpressure (compared with 3.2 psi for a clean filter). ${ }^{25}$ These values represent decreases of about $12 \%$ in resistance to shock waves, as a result of the dust loading used. In practice, filters may be loaded to pressure drops considerably higher than 4 in. $\mathrm{H}_{2} \mathrm{O}$.

Several $24 \times 24 \times 57 / 8$-in. filter units were obtained without the standard wire hardware cloth (1/4-in. wire mesh) face guards. These failed at overpressures of about $1.4 \mathrm{psi}$ (compared with $2.2 \mathrm{psi}$ for a $24 \times 24 \times$. $57 / 8$-in. filter with a face guard), a decrease of about $40 \%$ in resistance to shock waves.

From the NRL-NOL studies it was concluded that the longer and thinner the unsupported span of filter media, the lower is the resistance to shock, that the wire hardware cloth materially increases resistance to shock, and that methods of support for the center areas of the larger units would markedly improve shock-wave resiatancc.

Burchste. d $^{26}$ plot,ted shock overpressure resistance of clean HEPA filters without face guards as a function of the ratio of thickness (depth) of filter to face area. For three thicknesses, $31 / 16,57 / 8$, and $111 / 2$ in., he plotted a family of three straight-line curves of essentially identical slope, which graphically illustrated the need for face guards and perhaps center support for filter units that have large face areas, small thicknesses, or both. Burchsted ${ }^{27}$. recommended a similar plot for dirty filters, which would be more directly applicable to design for operating conditions. 
4.2.4 Resistance to Accident-Produced Pressure Differentials

During a postulated loss-of-coolant accident, the pressure of the containment atmosphere of a water-cooled reactor might rise to about 40 to 50 psig in a few seconds and impose a transient, but heavy, pressure differential on filters within the containment shell, especially filters whose upstream faces were directly exposed to the peak pressure. As part of the AEC's Air Filter Development Program, headed by Humphrey Gilbert (AEC-COS) and C. A. Burchsted (ORNL), tests of the resistance of HEPA filters to velocity-induced overpressures are being conducted. ${ }^{27}$ Results of these tests should permit a more quantitative assessment of the degree of protection needed by HEPA filters in the event of severe pressure transients.

Means of protecting filters and other system components against severe pressure differentials are mentioned in Chapter 6.

\section{References}

1. British Standard Method of Test for Low-Penetration Air Filters (Other than for Air Supply to I.C. Engines and Compressors), B.S. 3928: 1965, British Standards Institution, London, 1965.

2. British Standard Specification for Methods of Test for Air Filters Used in Air-Conditioning and General Ventilation, B.S. 2831: 1957 , British Standards Institution, London, 1957.

3. D. Hasenclever, The Testing of High-Efficiency Filters for the Collection of Suspended Particles, pp. 805-813 in International Symposium on Fission Product Release and 'l'ransport Under Accident Conditions, Oak Ridge, Tennessee, April 5-7, 1965, USAEC Report CONF650407 .

4. Quality Assurance Directorate, U. S. Army Edgewood Arsenal, Instruction Manual for Q76 DOP Filter Testing Penetrometer, Document No. 136-300-195A, and Instruction Manual for Q107 DOP Filter Testing Penetrometer, Document No. 136-300-175A, Edgewood Arsenal, Maryland. (These manuals are replacing MIL-STD-282 and will eventually be replaced by a USA standard.)

5. USAEC Health and Safety Information Issue. No. 253, Filter Unit Inspection and Testing Service, Fiscal Year 1968, Division of Operational Safety, USAEC, Washington, D. C., July 10, 1967; also USAEC Health and Safety Information Issue No. 212, Minimal Specificaton for the Fire-Resistant High-Efficiency Filter Unit, June 25, 1965. 
6. C. A. Burchsted, Requirements for Fire-Resistant High-Efficiency Particulate Air Filters, pp. 62-74 (esp. p. 64) in Proceedings of Ninth AEC Air Cleaning Conference, Boston, Massachusetts, Sept. 13-16, 1966, USAEC Report CONF-660904, Vol. 1, January 1967.

7. Humphrey Gilbert, comment on p. 447 in Panel B - Round Table Session: Specifications, Maintenance, and Monitoring of Filters, pp. 439-452 in Proceedings of Eighth AEC Air Cleaning Conference, Oak Ridge National Laboratory, October 22-25, 1963, USAEC Report TID-7677, March 1964.

8. H. W. Knudsen and L. White, Development of Smoke Penetration Meters, Report NRL-P-2642, IVaval Research Laboratory, Sept. 14, 1945.

9. J. W. Thomas, Aerosol Penetration Through Pinholed Filters, - Health Phys., 11: 667-673 (1965).

10. F. E. Adley and D. E. Anderson; The Effects of Holes on the Performance Characteristics of High-Efficiency Filters, pp. 494-507 in Proceedings of Eighth AEC Air Cleaning Conference, Oak Ridge National Laboratory, Oct. 22-25, 1963, USAEC Report TID-7677, March 1964.

11. E. C. Parrish and R. W. Schneider, Tests of High Efficiency Filters and Filter Installations at ORNL, USAEC Report ORNL-3442, Oak Ridge National Laboratory, May 17, 1963.

12. Earl Stafford and W. J. Smith, Ind. Eng. Chem., 43: 1346 (1951).

13. C. A. Burchsted, Oak Ridge National Laboratory, unpublished data, July 1966.

14. F. E. Adley, Hanford Occupational Health Foundation, personal communication to C. A. Burchsted, Oak Ridge National Laboratory, 1966.

15. R. H. Knuth, Performance of Defective High-Efficiency Filters, Am. Ind. Hyg. A330c. J., 26: 593-600 (November-December 1965).

16. C. $\Lambda$. Burchsted, Requilements for Fire-Resistant High-Efficiency Particulate Air Filters, pp. 62-74 (esp. p. 65) in Proceedings of Ninth AEC Air Cleaning Conference, Boston, Massachusetts, Sept. 13-16, 1966, USAEC Report CONF-660904, Vol. 1, January 1967.

17. R. E. Adams et al., Filtration of Stain.less Steel-UO $\mathrm{U}_{2}$ Aerosols, pp. 133-148 in Nuclear Safety Program Ann. Progr. Rept. Dec. 31, 1967, USAEC Report ORNL 1228 , Oak Ri dge National Laboratory.

18: R. E. Adams et al., Filtration of Particulate Aerosols Under Reactor Accident Conditions, USAEC Report ORNL-TM-1707, Oak Ridge National Laboratory, December 1966. 
19. R. J. Davis et al.; Filtration of Solid Aerosols, pp. $42-45$ in ORNL Nuclear Safety Research and Development Program Bimonthly Report November-December 1967, USAEC Report ORNL-TM-2095, Oak Ridge National Laboratory, February 1968. [Further information is contained under the same subtitle in preceding bimonthly reports: USAEC Reports ORNLTM-2057 (September-October 1967), ORNL-TM-1986 (July-August), ORNL-TM1913 (May-June), etc.]

20. W. S. Durant et al., Activity Confinement System of the Savannah River Plant Reactors, USAEC Report DP-1071, Savannah River Laboratory, August 1966.

21. A."H. Peters, Application of Moisture Separators and Particulate Filters in Reactor Containment, USAEC Report DP-812, Savannah River Laboratory, December 1962.

22. J. W. Walker and A. H. Peters, Filters for Reactor Containment, Mech. Eng., 85(9): 46-50 (1.963).

23. R. D. Rivers and J. L. Trinkie, Moisture Separator Study, USAEC Report NYO-3250-6, Connecticut Yankee Atomic Power Company, June 1966.

24. Standard UL-586, High Efficiency Air Filter Units, Underwriters' Laboratories, Inc., Chicago, Illinois, June 1964.

25. W. L. Anderson and T. Anderson, pp. 79-95 in Proceedings of Ninth AEC Air Cleaning Conference, Boston; Massachusetts, Sept. 13-16, 1966, USAEC Report CONF-660904, Vol. 1, January 1967.

26. C. A. Burchsted, Requirements for HEPA Filters, pp: 226-230 in Proceedings of Sixth Annual Technical Meeting of American Association for Contamination Control, Washington, D.C., May 15-18, 1967, published by American Association for Contamination Control; Boston, 1967.

27. C. A. Burchsted, Oak Ridge National Laboratory, personal communication. 


\section{PERFORMANCE AND TESTING OF CHARCOAL ADSORBERS}

Beds of activated charcoal have high efficiency for the trapping of radioactive molecular iodine $\left({ }^{13} I_{2}\right)$ if (1) the charcoal has not lost efficiency from long exposure to moisture or impurities in the air, (2) it is not ignited, (3) it has not settled to the extent that air bypasses the charcoal through leakage paths, and (4) waterlogging (extensive flooding of the beds) is prevented. Conventional (unimpregnated) activated charcoals, however, do not efficiently remove methyl iodide or other organic iodides.

At present, the only effective means of preventing the release of radioactive methyl iodide $\left(\mathrm{CH}_{3}{ }^{131} \mathrm{I}\right)$ through recirculating air-cleaning systems after a postulated loss-of-coolant accident in a water-cooled power reactor is removal of the radioactive iodine from the methyl iodide by isotopic exchange. For this purpose, activated charcoal is impregnated with one or more substances containing nonradioactive iodine ( $\left.{ }^{127} \mathrm{I}\right)$, which exchanges with the radioactive ${ }^{13} I$ In the methyl iodide as the air being cleaned passes through the charcoal bed. In this manner the impregnated charcoal. removes and traps the radioactive ${ }^{13} I I$ and releases nonradioactive $\mathrm{CH}_{3}{ }^{127} \mathrm{I}$. Some methyl iodide, as such, may be trapped by the impregnated charcoal, but the main trapping mechanism is the isotopic exchange. Five commercially available impregnated charcoals have been shown to be effective at humidities as high as $70 \%$ and possibly higher if waterlogging is prevented.

Beds of activated charcnal must be designed to prevent or counteract settling. Leaks that bypass air around the charcoal can drastically reduce or destroy the capability of charcoal beds. This is also true of leakage caused by channeling in charcoal beds extensively f'looded with water: Activated charcoals, particularly impregnated charcoals, must be protected against ignition by fission-product decay heat. Furthermore, impregnated charcoal will release some of its impregnant and may release trapped fission-product iodine and iodine compounds if subjected to excessive heat well below its ignition temperature. Long-term exposure to flowing humid air causes a gradual decrease in efficiency, and this decrease is arrelerated if the air contains significant amounts of impurities. 
For the reasons outlined above, charcoal beds that are depended on to perform reliably after a postulated accident must, like HEPA filters, be protected against damage or loss of function by well-designed and carefully maintained systems.

With the identification of methyl iodide (and smaller amounts of other organic iodides) as the fraction of fission-product iodine that was penetrating charcoal adsorbers and the development of impregnated charcoals capable of efficiently removing organic iodides at high humidities, the simulation of accident-produced fission products for the testing of charcoal adsorbers has become, in most respects, a simpler problem than the simulation of fission products for the testing of HEPA filters. There are two reasons for this. First, HEPA filters are provided for the removal of all particulate fission products and other particulate radioactive material from the air being cleaned by them, whereas charcoal beds are provided primarily to remove iodine and its gaseous compounds, although they do remove very small amounts of other chemically active fission-product gases and can serve to hold up noble gases for radioactive decay. Second; HEPA filters must be capable of more or less simultaneously removing particulate materials in a wide spectrum of particle sizes and of various shapes, whereas charcoal beds, which are almost invariably protected by HEPA filters upstream, are faced only with gases, some vapors, and the very small amount of particulates that pass through the HEPA filters.

In at least two ways, the simulation of accident-produced fissionproduct iodine and iodides is quite complex. First, the simulant gases should represent those that would actually be released from high-burnup fuel elements, escape sorption and plateout within the containment structure, and reach the charcoal under postaccident conditions. Second, the amount of iodine that would reach the charcoal in the form of organic iodides is still far from being known definitively, although it has been tentatively established as a small fraction of the total amount of iodine that reaches the charcoal beds.

No standard quality-assurance test of the efficiency of charcoal beds for reactor installations has yet been adopted on a USAEC-wide scale. 
However, a standard set of tests will quite possibly be adopted in the near future, as discussed in Section 5.1.1.

\subsection{Efficiency Testing of New and Recharged Charcoal Beds}

Standard testing of the efficiency of new and recharged charcoal beds may include a test for efficiency in removing molecular iodine, a test for efficiency in removing methyl iodide, and perhaps a leak test with a gas other than iodine. Qualification tests will also include a test of the total capacity of representative samples for iodine and methyl iodide. Although a standard set of tests has not yet been adopted on an AEC-wide scale, the tests that will probably comprise the set have been used for several years.

Standard efficiency tests may be based on the two tests with small amounts of radioactive ${ }^{13}{ }^{1} I_{2}$ and $\mathrm{CH}_{3}{ }^{13 I} \mathrm{I}$ that are used as in-place tests of beds of impregnated charcoal at the Oak Ridge National Laboratory. ${ }^{1}$ Alternatively, if acceptable the tests may be a combination of the ORNL efficiency tests and a leak test with DuPont Freon-112, which was developed by the Savannah River Laboratory and is used routinely at the Savannah River Plant. 2,3 In the latter case, all beds, whether new or recharged with new charcoal, could be subjected to quality-assurance leak tests with Freon-112, and representative beds and/or representative samples of impregnated charcoal from production runs could be tested for iodine-removal efficiency and capacity with small amounts of radioactive ${ }^{13}{ }^{1} I_{2}$ in a nonradioactive ${ }^{127} I_{2}$ carrier and with small amounts of $\mathrm{CH}_{3}{ }^{131} \mathrm{I}$ in $\mathrm{CH}_{3}{ }^{127} \mathrm{I}$.

Unlike the test of HEPA filters with thermally generated monodisperse 0.3- $\mu$ DOP, which is widely accepted as a test of the efficiency of the filters for removal of particulates, the test of charcoal beds with Freon112 is not considered a test. of the efficiency of the beds for the removal of iodine and its gaseous compounds. It is considered a very useful leak test, as is the in-place test of HEPA filters with compressed-air-generated polydisperse DOP.

Fortunately, it is both technologically and economically practical to test the efficiency of at least representative samples of charcoal 
with the very materials for which charcoal beds are provided, ${ }^{13}{ }^{1} I_{2}$ and $\mathrm{CH}_{3}{ }^{131} \mathrm{I}$. A number of methods of testing the efficiency of charcoal beds with iodine but without using ${ }^{13 I}$ I as a tracer have been used or tried. Among these methods are neutron activation of stable iodine, ${ }^{4}$ catalytic reduction of ceric ions by iodine, 5 and detection of iodine as an oxidant. 6 However, the efficiency of impregnated charcoal for removal of methyl iodide and other organic iodides can only be tested with an organic compound of radioactive iodine which, as a compound, penetrates activated charcoal as easily as methyl iodide does. The reason for this is that impregnated charcoal is specific for the removal of radioactive iodine from methyl iodide by isotopic exchange, as discussed in the introductory part of this chapter.

The probable standard efficiency tests outlined in this section would not differ basically from the in-place iodine tests discussed in Chapter 6 . The Freon-112 leak test would differ from in-place tests of used charcoal. beds in that the test conditions of air velocity and amount of sorbed water are less restrictive for new beds (also discussed in Chapter 6).

A facility for testing charcoal beds, trained personnel to operate it, full laboratory services, and evaluation of the data in accordance with customer requirements are available at the Westinghouse Atomic Power Division. The facility, known as the WAPD Filter Test Facility, ${ }^{7}$ can be transported for on-site testing of charcoal units with test gases in airsteam mixtures at a maximum velocity of $1000 \mathrm{cfm}$ and a maximum temperature of $320^{\circ} \mathrm{F}$. The facility can be used with radioactive or nonradioactive $\mathrm{I}_{2}$, $\mathrm{HI}$, or $\mathrm{CH}_{3} \mathrm{I}$ or with Freon or other compounds and is equipped for tracer assay and gas chromatography.

\subsection{Efficiency for Molecular Iodine Removal Under} Simulated Postaccident Conditions

Although molecular iodine is expected to constitute the largest fraction of fission-product iodine that would reach charcoal beds after a postulated reactor accident, it is effectively removed by either conventional activated charcoals or impregnated activated charcoals, subject to the restrictions that the charcoal must not have excessively deteriorated or 
settled or have become waterlogged. Conventional (unimpregnated) charcoals are still in use in some reactor air-cleaning systems. (The limited applicability of unimpregnated charcoals to methyl iodide removal is discussed in sect. 5.3.1.)

Tests of charcoal efficiencies under simulated accident conditions have been concentrated on impregnated charcoals during the past three years, and it is during this time that tests have simulated the postulated temperatures and pressures (about $275^{\circ} \mathrm{F}$ and 40 to $50 \mathrm{psig}$ ) under which charcoal beds would operate in recirculating filter-adsorber systems within the containment shell. Unimpregnated charcoals have not been tested at these temperatures and pressures, but they have been tested with air 80 to $90 \%$ saturated with steam at 95 to $100^{\circ} \mathrm{C}$ (203 to $212^{\circ} \mathrm{F}$ ). These humidities and temperatures do simulate certain postulated accident conditions and may be more severe than the postaccident conditions under which charcoal beds would operate in once-through filter-adsorber systems in secondary containment buildings (or in slow purges of diluted air from within containment shells). Tests of unimpregnated charcoal under accident conditions were performed during 1961-1964 for the N.S. SAVANNAH Project ${ }^{8}$ and during 1964-1965 for the evaluation of charcoal adsorbers as engineered safety features. ${ }^{9}$

In the N.S. SAVANNAH studies, laboratory tests were made on charcoal units 11 in. square and $11 / 8$ in. thick containing $12 / 30$ mesh Pittsburgh BPL charcoal. Iodine vapor ( ${ }^{127} I$ labeled with ${ }^{13} I$ ) in the concentration expected in a postulated reactor accident on the N.S. SAVANNAH $\left(10^{-2} \mathrm{mg}\right.$ per cubic meter of steam-air) was continuously injected into air that was 80 to $90 \%$ saturated with steam at 96 to $100^{\circ} \mathrm{C}$, and the mixture was passed through the charcoal units at 4.3 to $5.0 \mathrm{ft} / \mathrm{min}$ to give a residence time of about 1.0 to $1.1 \mathrm{sec}$. The efficiency of the charcoal for the removal of iodine under these conditions was $99.86 \pm 0.07 \%$ at the $95 \%$ confidence level. ${ }^{8}$ It was discovered during subsequent tests in the N.S. SAVANNAH studies that what is now known to be methyl iodide may have constituted part of the iodine, and the actual efficiency for molecular iodine may have been higher than the value reported. 10 
During-1964-1965, just before commercial impregnated charcoals were shown to be superior for radioactive methyl iodide removal, studies were conducted at ORNL for the evaluation of unimpregnated charcoal adsorbers as engineered safety features. ${ }^{9}$ (One of the charcoals was Whetlerite, a charcoal impregnated with salts of silver, copper, and chromium, but it did not contain the impregnants now used.) In these studies, four charcoals were tested in 1.5-in.-deep beds for their efficiency for the removal of molecular iodine (and methyl iodide) from.steam-air systems. Steam saturation of the air in eight molecular iodine removal tests ranged from 56.3 to $90.7 \%$, temperatures ranged from 95 to $180^{\circ} \mathrm{C}$, and linear gas velocities ranged from 27.9 to $39.6 \mathrm{ft} / \mathrm{min}$. These velocities were much closer to the velocities in power reactors of current design (60 to $70 \mathrm{ft} / \mathrm{min}$ ) than were those in the N.S. SAVANNAH studies. However, there was no apparent correlation between velocity and efficiency in the range of velocities used.

The average measured efficiency for the removal of molecular iodine in the eight tests was about 98\%, but the actual efficiency for molecular iodine removal per se may have been much higher. These studies involved early attempts to fractionate iodine sources. The more volatile fraction (organic iodides; mainly methyl iodide) from a palladium iodide source maintained at $-70^{\circ} \mathrm{C}$. was removed by passing air for $10 \mathrm{~min}$ through a tube containing the source. The remaining; less volatile fraction was used in the tests. of molecular iodine removal efficiency. This fraction, which was mainly molecular iodide, was known to contain some compounds of iodine, and it is now believed ${ }^{l}$ that it probably contained a considerable amount of methyl iodide and that the average measured efficiency of $98 \%$ was much lower than the actual efficiency.

\subsection{Et't'iciency for Methyl Iodide Removal Under} Simulated Postaccident Conditions

The formation, reactions, and transport of methyl iodide and other organic iodides within the containment system of a water-cooled power reactor during and after a loss-of-coolant accident.would depend on many parameters, such as containment atmosphere, bare or painted surfaces, 
temperatures, iodine concentrations, and surface-to-volume ratios. The amount of iodine that would reach the charcoal beds in the form of methyl iodide or other organic iodides cannot yet be quantitatively predicted, but it is considered to be a small percentage of the total iodine inventory and a somewhat larger percentage of the airborne iodine.12-16 However, it is generally assumed that the amount of methyl iodide will be significant.17-19 For siting in or near population centers, assurance of a high efficiency for the removal of methyl iodide may be required.

\subsubsection{Conventional Activated Charcoals}

Conventional activated charcoals are not adequate for the postaccident removal of methyl iodide in recirculating air-cleaning systems within the containment shell, of water-cooled power reactors. Conventional coconut-base activated charcoals have adequate efficiencies for the removal. of methyl iodide in filter-adsorber systems in the exhaust of secondary containment structures, but only if it can be assured that humidity can be reduced to very low levels.

In laboratory studies of an unimpregnated coconut charcoal at room temperature, efficiency for the removal and retention of methyl iodide was drastically reduced as the relative humidity of the air was increased; efficiency also tonded to vary inversely with air velocity. Time periods over which removal efficiencies greater than $90 \%$ were observed varied from about $100 \mathrm{hr}$ at less than 3\% relative humidity, 10-ft/min air velocity, and a charcnal bed depth of $3 \mathrm{in}$. to less than $0.2 \mathrm{hr}$ at near $100 \%$ relative humidity, $100 \mathrm{ft} / \mathrm{min}$, and a bed depth of 1 in. ${ }^{20}$ The efficiency of a 2 -in.-deep bed at $60 \%$ relative humidity and $10 \mathrm{ft} / \mathrm{min}$ fell below $90 \%$ in about ? hr. The conditions of these tests did not simulate the high temperatures and pressures typical of the atmosphere within the containment shell after a postulated loss-of-coolant accident. The tests at various humidities were sufficient to show that conventional activated charcoals are not adequate for methyl iodide for useful lengths of time unless the humidity of the air passing through the charcoal beds can be kept low.

The Vermont Yankee reactor plant design and analysis report states that the charcoal unit on the EVESR at Vallecitos Atomic Power Laboratory 
has been retaining organic halogens produced during power operation with an efficiency of 99.8 to $99.9 \%$ at a relative humidity of 10 to $15 \% .21$ This charcoal is not impregnated, but the low humidities at which these removal efficiencies are reported must be noted. In a small system of this type, low humidities can be easily achieved.

\subsubsection{Commercial Impregnated Charcoals}

Activated coconut charcoals impregnated with one or more substances containing nonradioactive iodine have been known for over two years to have very good efficiencies for the removal of radioactive iodine from methyl iodide at fairly high humidities, ambient pressure, and ambient or moderately high temperatures (up to $115^{\circ} \mathrm{F}$ ).14,15,20 In reçent tests, 22, 23 five commercial impregnated charcoals have been shown to be effective for methyl iodide removal at the temperature, pressure, and humidity predicted for the atmosphere within the containment shell of a water-cooled power reactor after.a loss-of-coolant accident, provided extensive flooding of the charcoal beds can be prevented and, preferably, humidity within the charcoal beds does not exceed 90\%.

These five charcoals are MSA 85851 and MSA 24207 (Mine Safety Appliances Company), $\mathrm{BC}-727$ and $\mathrm{BC}-239$ (Barnebey-Cheney), and G601 (North American Carbon, Inc.). The impregnants of these commercial charcoals are proprietary and therefore are not precisely specified in Refs. 22 and 23. It can be said that the impregnants are one or more substances containing nonradioactive ${ }^{127} \mathrm{I}$, which removes radioactive ${ }^{131} \mathrm{I}$ from $\mathrm{CH}_{3}{ }^{131} \mathrm{I}$ by isotopic exchange and releases nonradioactive $\mathrm{CH}_{3}{ }^{127} \mathrm{I}$.

At about $270^{\circ} \mathrm{F}$ and $55 \mathrm{psia}$, with $50 \mathrm{ft} / \mathrm{min}$ steam-air velocity and $3.5 \mathrm{mg}$ of $\mathrm{CH}_{3}$ I injected per gram of charcoal, 2-in.-deep beds of each of the five commercial charcoals tested had efficiencies of $90 \%$ or higher for the removal of ${ }^{131} \mathrm{I}$ from $\mathrm{CH}_{3}{ }^{131} \mathrm{I}$, provided the prevailing relative humidity of the charcoal did not greatly exceed 90\% (Fig. 5.1). At 80 to $85 \%$ relative humidity, efficiencies of $98 \%$ or higher were typical. 23

At indicated relative humidities of or near $100 \%$, under which condition extensive flooding (waterlogging) of the carbon beds can be caused by condensation of the steam, efficiencies dropped to low or very low 


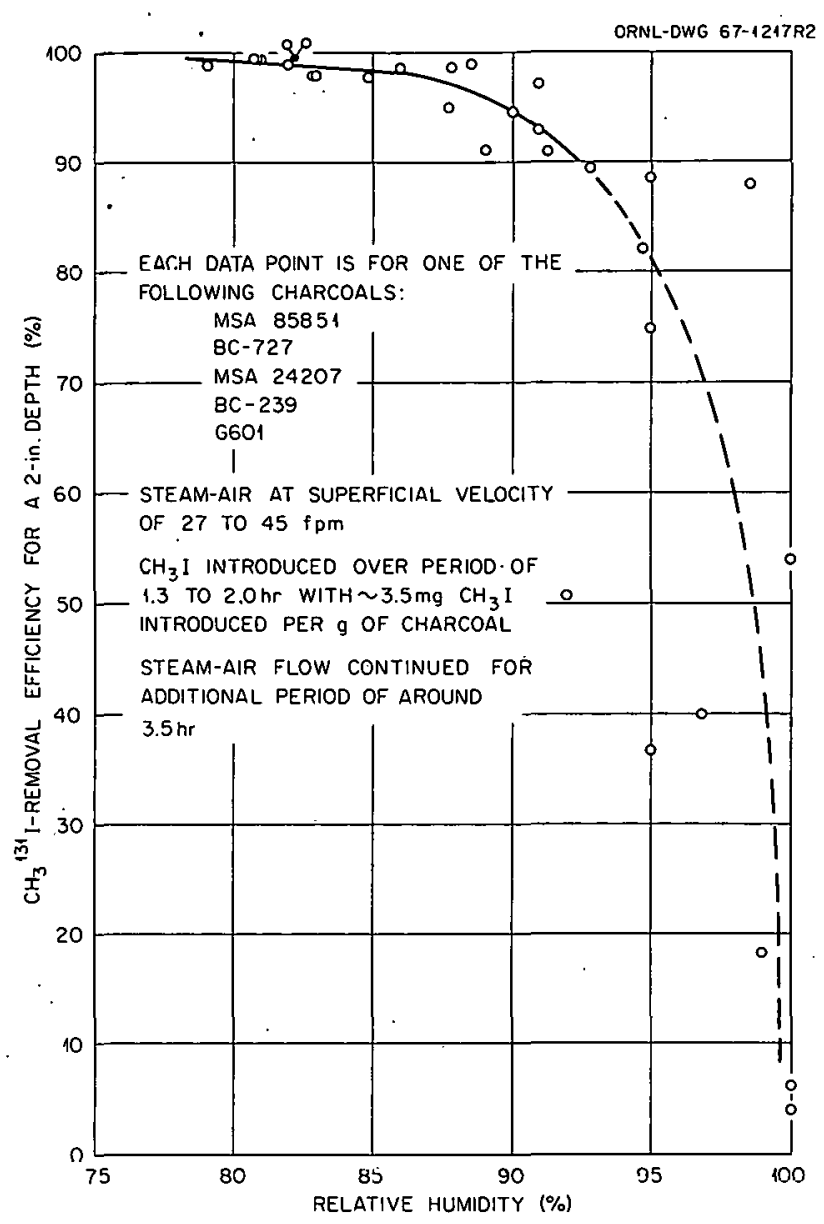

Fig. 5.1. Effect of Relative Humidity on the Removal of ${ }^{131} \mathrm{I}$ from $\mathrm{CH}_{3}{ }^{131} \mathrm{I}$ in Flowing Steam-Air by Commercial Iodized Charcoals at Temperatures and Prcssures Around $270^{\circ} \mathrm{F}$ and $60 \mathrm{psia}$. Bed depth, 2 in. (From Ref. 22)

levels. Although it was stated that useful efficiency might possibly be attainable at relative humidities approaching 100\%, it was recommended that operation in the 90 to $100 \%$ relative humidity range be avoided. ${ }^{24}$ It was also commented that these results were obtained on a single-pass (once-through) systell and that higher total efficiencies would probably he achieved in a recirculating system; however, it was stated that weathering and poisoning of the charcoal (see Sect. 5.2) should be considered in operating off-gas systems. 
5.3.3 Differences Between U.S. Recommended Charcoals and Those Recommended by the UKAFA Reactor Development Laboratory

The impregnated charcoals used in the containment systems of watercooled power reactors in the United States differ in several respects from those recommended by investigators at the UKAEA Reactor Development Laboratory at Windscale. In intensive studies at Windscale, including tests of a number of inorganic and organic impregnants, two impregnated charcoals gave the best results. Both of these were prepared from the same coal-base charcoal (Sutcliffe Șpeakman and Company, Ltd., Type 207B). One, designated $0.5 \% \mathrm{KI} / 207 \mathrm{~B}$, is impregnated with $0.5 \mathrm{wt} \%$ potassium iodide; the other, designated 5\% TEDA/207B, is impregnated with 5 wt \% triethylenediamine. Findings that each had advantages over the other led to the recommendation ${ }^{25}$ of a mixture of the two for use in reactor containment systems.

For KI-impregnated charcoal, the best performance in the Windscale tests was considered to be in the range 0.1 to 1 wt.\%.KI, and 0.5 wt $\%$ was selected as being in the middle of that range. 26 However, the performance curve was stated to be virtually flat over an impregnant concentration range of almost two orders of magnitude. On the $K I$ curve in Fig. 6 of Ref. 25, this would extend from about 0.05 to 5.0 wt $\%$ on the logarithmic absrissa scale. The oclectivii ur 0.5 wt \% rather than a higher concentration of impregnant may have been governed largely by findings 26 that $0.5 \mathrm{wt} \% \mathrm{KI}$ lowered the ignition point of $207 \mathrm{~B}$ charcoal (about $500^{\circ} \mathrm{C}$ ) to approximately that of unimpregnated charcoal (about $350^{\circ} \mathrm{C}$ ). (Coconut charcoals, both unimpregnated and impregnated, with ignition points close to those of coal-base charcoals, have been under investigation in the United States for some time, as discussed in Sect. 5.2.)

The $0.5 \% \mathrm{KI} / 207 \mathrm{~B}$ chosen was found to have an acceptable $\mathrm{CH}_{3} \mathrm{I}$ loading of only slightly over $100 \mathrm{\mu g} / \mathrm{g}$, whereas serious overloading of the $5 \%$ TEDA/207B did not occur until it was loaded with well over $1 \mathrm{mg} / \mathrm{g} \cdot{ }^{27} \mathrm{Be}-$ cause of the far greater total capacity of 5\% TEDA/207B (and for other reasons of lesser importance), a mixture of the two impregnated charcoals was recommended, although tests indicated 28 that TEDA was much more subject to loss by volatilization at high temperatures than was $K I$. 
The charcoals recommended for use in the United States contain about 5 wt. \% impregnant, compared with 0.5 wt $\%$ in the $0.5 \% \mathrm{KI} / 207 \mathrm{~B}$. Although the proprietary impregnants cannot be specified here, they are known to contain iodine and to function primarily by isotopic exchange, and they have useful efficiencies for $\mathrm{CH}_{3} \mathrm{I}$ at loadings of about $3.5 \mathrm{mg}$ of $\mathrm{CH}_{3} \mathrm{I}$ per gram of charcoal (Sect. 5.1) compared with only about $100 \mu \mathrm{g}$ quoted (under different conditions) for $0.5 \% \mathrm{KI} / 207 \mathrm{~B}$. Therefore, the addition of a complementary charcoal, such as one impregnated with triethylenediamine, is not recommended. Despite the restrictions (Sect. 5.2) on the conditions under which they must be used in order to be effective, it is emphasized that these commercial impregnated charcoals are strongly recommended for water-cooled power reactors in the United States.

\subsubsection{Use of Unimpregnated Charcoals at the Savannah River Plant}

Unimpregnated charcoal is presently specified for the activity confinement system of the Savannah River Plant reactors. ${ }^{29}$ Under the assumed accident conditions. for these reactors, the production of methyl iodide has been considered to be negligible.20,30 For the removal of molecular iodine, the unimpregnated charcoal used in the SRP reactors has certain advantages over impregnated charcoals; notably, a higher ignition point and the questionable advantage that, having no impregnant, it cannot lose impregnant by volatilization on heating. Where provision for methyl iodide removal must be made, however, this charcoal is not recommended: It is inadequate for the removal of methyl iodide in recirculating systems within the containment atmosphere, and it is adequate in once-through systems provided to clean up the less humid atmosphere of a refueling building or other secondary containment structure only if very low humidity can be assured and if the amount used is much larger than the amount of impregnated charcoal required for the same application.

\subsection{Prevention of Charcoal Ignition}

Adsorption systems must be designed so that the decay heat of collected fission products will not cause combustion of their media or 
result in overheating to a temperature at which collected fission products will be redispersed. Heat-resistant prefilters should be used. to collect the initial load of fission products that generate excessive fission heat. Normal air cooling of the filter usually holds the temperature of the charcoal below its ignition temperature ( 250 to $300^{\circ} \mathrm{C}$ ). Once ignition starts, however, air flow accelerates the combustion process. Small fires may be extinguished by cutting off the air (oxygen) supply. Larger fires may require water fog sprays and continued air flow to cool down the system and prevent reignition of the charcoal. The Savannah River Laboratory (SRL) is studying adsorbers that will reduce the possibility of igniting existing types of coconut-shell carbon in some reactor containment systems. In addition, a standardized procedure is being developed to measure the ignition temperature, to evaluate promising new types of carbon, and to evaluate the effects of such variables as air flow, particle size, internal surface area, and catalysts on the ignition temperature. 31

A small-scale apparatus was developed at SRL for measuring ignition temperatures of carbon beds with diameters and depths of up to 3 in. The 3-in. diameter was chosen to simulate a full-sized bed. An ignition temperaturé of 340 to $350^{\circ} \mathrm{C}$ was measured for a l-in.-thick bed packed with a sample of the unimpregnated activated coconut carbon (Barnebey-Cheney type 4i6) now used in the Savannah River Plant. (SRP) confinement system. ${ }^{1}$ Air velocities from 10 to $125 \mathrm{ft} / \mathrm{min}$ had little effect on the ignition temperature. Exposure in the confinement systems for about two years increased the ignition temperature about $80^{\circ} \mathrm{C}$. Ignition tests on carbon with about $31 / 2$ years of exposure were in progress at the time of reporting. An ignition temperature of approximately $530^{\circ} \mathrm{C}$ was measured at a velocity of $105 \mathrm{ft} / \mathrm{min}$ for samples of a new type of high-temperature coconut carbon (Barnebey-Cheney type 592) packed in a 1-in.-thick bed. ${ }^{31}$ Detailed evaluation of the iodine adsorption and the ignition characteristics of this promising new carbon is in progress at SRL. Preliminary tests indicate that the new carbon meets SRP specifications. ${ }^{32}$ The ignition temperatures of several other commercial carbons were also measured. Activated carbon prepared from bituminous coal ignited at $480^{\circ} \mathrm{C}$ 
and coconut carbon ignited at $340^{\circ} \mathrm{C}$. An ignition temperature of only $250^{\circ} \mathrm{C}$ was measured for whetlerite carbon.

The possibility exists that decay heat from adsorbed iodine might lower the bulk temperature for ignition of charcoal by producing hot spots as a result of nonuniform distribution of the adsorbed iodine. This possibility has been investigated at ORNL by generating short-lived iodine isotopes in overheated $\mathrm{UO}_{2}$ and blowing them into a charcoal adsorber. Preliminary results of these studies indicate that the charcoal ignition temperature is not greatly affected by the decay heat of the adsorbed fission products. The results of this first series of experiments indicate that the experimental apparatus is capable of producing the desired ignition data and that the decay heat loading of the charcoal is adequate. 33,34

Ignition temperatures of $340^{\circ} \mathrm{C}$ for type 416 carbon and $530^{\circ} \mathrm{C}$ for type 592 carbon were measured in tests at the Lawrence Radiation Laboratory on a full-size prototype of the new SRP beds framed with stainless steel.31,35. This value was in good agreement with that obtained from the small-scale apparatus at SRL. The air flow during the test was maintained at $1000 \mathrm{cfm}$, corresponding to a face velocity of $70 \mathrm{ft} / \mathrm{min}$. At ignition, glowing particles of carbon were swept from the bed. Simultaneously, thermocouples in . the bed suddenly indicated temperatures higher than the $540^{\circ} \mathrm{C}$ limit of the recorder. The burners and air flow were stopped immediately after the carbon ignited. Carbon dioxide sprayed on the upstream face did not extinguish the fire, which was extinguished by restoring the air flow and spraying water on both faces of the bed for about $15 \mathrm{~min}$.

\section{$\underline{\text { References }}$}

1. J. H. Swanks, In-Place Iodine Filter Testing, pp. 1092-1104 in Proceedings of Ninth AFC Air Cleaning Conference, Boston, Mass., September 13-16, 1966, USAEC Report CONF-660904, Vol. 2, January 1.967.

2. W. S. Durant et al., Activity Confinement System of the Savannah River Plant Reactors, USAEC Report DP-1071, Savannah River Plant, August 1966. 
3. D. R. Muhlbaier, Standardized Nondestructive Test of Carbon Beds for Reactor Confinement Applications, Final Progress Report, February to June 1966, USAEC Report DP-1082, Savannah River Plant, July 1967.

4. C. A. Gukeisen and K. L. Malaby, In-Place Testing of Charcoal Filter Banks at Ames Laboratory Research Center (ALRR), pp. 1063-1068 in Proceedings of Ninth AEC Air Cleaning Conference, Boston, Mass:, September 13-16, 1966, USAEC Report CONF-660904, Vol. 2, January 1967.

5. F. J. Viles, Jr., and L. Silverman, In-Place Iodine Removal Efficiency Test, pp. 1108-1132 in Proceedings of Ninth AEC Air Cleaning Conference, Boston, Mass., September 13-16, 1966, USAEC Report CONF660904, Vol. 2, January 1967.

6. W. G. Thoms on and R. E. Grossman, In-Place Testing for Iodine Removal Efficiency Using an Electronic Detector, pp. 1134-1149 in Proceedings of Ninth AEC Air Cleaning Conference, Boston, Mass., September 13-16, 1966, USAEC Report CONF-660904, Vol. 2, January 1967.

7. WAPD Filter Test Facility and Services, Westinghouse Atomic Power Division, Pittsburgh, Penna. (Details on the facility, related services, and arrangements can be obtained from D. C. Beatty, Manager of Nuclear Power Service, Westinghouse Atomic Power Division, P.O. Box 355, Pittsburgh, Penna. 15230.)

8. R. E. Adams and W. E. Browning, Jr., Iodine Vapor Adsorption Studies for the N.S. Savannah Project, pp. 3-10 in USAEC Report ORNL-3726, Oak Ridge National Laboratory, February 1965.

9. R. E. Adams and W. E. Browning, Jr., Removal of Iodine and Volatile Iodine Compounds from Air Systems by Activated Charcoal, pp. 869-884 in International Symposium on Fission Product Release and Transport Under Accident Conditions, Oak Ridge, Tennessee, April 5-7, 1965, US $\Lambda$ EC Report CONF-650407, Vol. 2 .

10. R. E. Adams and W. E. Browning, Jr., Iodine Vapor Adsorption Studies for the N.S. Savannah Project, pp. 25-30 in USAEC Report ORNL-3726, Oak Ridge National Laboratory, February 1965.

11. R. E. Adams, Oak Ridge National Laboratory, personal communication.

12. J. Mishima, Methyl Iodide Behavior in Systems Containing Airborne Radioiodine, Nucl. Safety, 9(1): 35-42 (1968); esp. p. 40.

13. W. E. Browning, Jr., comment on p. 1191 in Discussion, pp. 1175-1193 in Proceedings of Ninth AEC Air Cleaning Conference, Boston, Mass., September 13-16, 1966, USAEC Report CONF-660904, Vol. 2, January 1967. 
14. R. E. Adams, W. E. Browning, Jr., W. B. Cottrell, and G. W. Parker, The Release and Adsorption of Methyl Iodide in the HFIR Maximum Credible Accident, USAEC Report ORNL-TM-1291, Oak Ridge National Laboratory, October 1965.

15. G. W. Keilholtz, Filters, Sorbents, and Air Cleaning Systems as Engineered Safeguards in Nuclear Installations, USAEC Report ORNLNSIC-13, Oak Ridge National Laboratory, October 1966.

16. J. Mishima, Review of Methyl Iodide Behavior in Systems Containing Airborne Radioiodine, USAEC Report BNWL-319, Pacific Northwest Laboratory, June 1966.

17. R. D. Ackley and R. E. Adams, Removal of Radioactive Methyl Iodide from Steam-Air Systems (Test Series II), USAEC Report ORNL-4180, Oak Ridge National Laboratory, October 1967.

18. Safety Evaluation by the Division of Reactor Licensing, USAEC, in the Matter of Consolidated Edison Company of New York, Inc., Indian Point Nuclear Generating Unit No. 2, Peekskill, New York, Docket No. 50-247, Aug. 25, 1966, p. 64 .

19. Safety Evaluation by the Division of Reactor Licensing, USAEC, in the Matter of Philadelphia Electric Company, Peach Bottom Atomic Power Station Unit Nos. 2 and 3, Peach Bottom Township, York County, Pennsylvania, Docket Nos. 50-277 and 50-278, Nov. 7, 1967, p. 34.

20. R. D. Ackley et al., Retention of Methyl Iodide by Charcoal Under Accident Conditions, pp. 61-80, in Nuclear Safety Program Semiann. Progr. Rept. Dec. 31, 1965, USAEC Report ORNL-3915, Oak Ridge National Laboratory.

21. Vermont Yankee Nuclear Power Station Plant Design and Analysis Report, Docket No. 50-271, p. XIV-3-29, 1966.

22. R. E. Adams, R. D. Ackley, and W. E. Browning, Jr., Removal of Radioactive Methyl Iodide from Steam-Air Systems, USAEC Report ORNL-4040, Oak Ridge National Laboratory, January 1967.

23. R. D. Ackley and R. E. Adams, Removal of Radioactive Methyl Iodide from Steam-Air Systems (Test Series II), USAEC Report ORNL-4180, Oak Ridge National Tahoratory, October 1967.

2i. R. D. Ackley and R. E. Adams, Removal of Radioactive Methyl. Iodide from Steam-Air Systems (Test Series II), p. 14 in USAEC Report ORNL4180, Oak Ridge National Laboratory, October 1967.

25. D. A. Collins, L. R. Taylor, and R. Taylor, The Development of Impregnated Charcoals for Trapping Methyl Iodide at High Humidity., British TRG Report 1300(W), p. 12, paragraph 65, 1967. 
26. Ibid., p. 5, paragraph 24, Fig. 6 .

27. Ibid., p. 5, paragraph 25.

28. Ibid., p. 7, paragraph 36.

29. W. S. Durant et al., Activity Confinement System of the Savannah River Plant Reactor, USAEC Report DP-1071, Savannah River Plant, August 1966.

30. Comments by G. W. Parker and A. H. Peters in Discussion, p. 370 in Proceedings of Ninth AEC Air Cleaning Conference, Boston, Mass., September 13-16, 1966, USAEC Report CONF-660904, Vol. 1, January 1967.

31. R. C. Milham, High Temperature Adsorbents for Iodine, Progress Report: January 1965-September 1966, USAEC Report DP-1075, Savannah River Laboratory, December 1966.

32. W. S. Durant, Performance of Activated Carbon Beds in SRP Reactor Confinement Facilities, Progress Report: September 1962-September 1965, USAEC Report DP-1028, Savannah River Laboratory; January 1966.

33. W. E. Browning, Jr., et al., Ignition of Charcoal Adsorbers by Fission-Product Decay Heat, pp. 156-167 in Nuclear Safety Program Semiann. Progr. Rept. June 30, 1965, USAEC Report ORNL-3843, Oak Ridge National Laboratory, September 1965.

34. W. E. Browning, Jr., et al., Ignition of Charcoal Adsorbers by Fission-Product Decay Heat, pp. $81-85$ in Nuclear Safety Program Semiann. Progr. Rept. Dec. 31, 1965, USAFC Report ORNL-3915, Oak Ridge National Laboratory, March 1966.

35. W. S. Durant et al., Activity Confinement System of the Savannah River Plant Reactors, USAEC Report DP-1071, Savannah River Laboratory, August 1966. 


\section{PERFORMANCE AND TESTING OF FILTER-ADSORBER SYSTEMS}

Under optimum conditions, the efficiencies of HEPA filters for the removal of particulate fission products and of any one of several impregnated charcoals for the removal of ${ }^{131} \mathrm{I}$ and its gaseous compounds are excellent. The most critical factors in the adequacy of filter-adsorber systems as engineered safety. features are matters of adequate funds and space allocation, meticulous design, thoroughgoing operational procedures, administrative control, and compliance. Filters and charcoal must be protected from damage and deterioration, particularly during and after an accident, and the integrity of the system and all of its components must be maintained. The air must be pretreated to minimize the reduction of filter and charcoal efficiency by excessive moisture and clogging by large particles. In-service testing, inspection, and maintenance of the system and its components must be effective. Any component subject to deterioration or loss of function must be replaced, when necessary, well in advance of the end of its safe service life.

\subsection{In-Place Testing of Filter-Adsorber Systems}

The performance of a once-through filter-adsorber system depends almost entirely on its efficiency and integrity. These systems generally exhaust cleaned air (after holdup time for decay of noble gases) through a high stack into the outside atmosphere. Therefore they must, and do, have high efficiencies for the removal of particulate and gaseous fission products during a single pass through the system.

The performance of a recirculating filter-adsorber system depends not only on the efficiency and integrity of the system, but also on the duration of the release of fission products into the containment shell, the dcgree of mixing within the containment shell, and the number of air changes per hour. (Air changes per hour is the conventional way of expressing the ratio of the volume of containment air that passes through the filter-adsorber system per unit time to the total volume of air within the containment shell.) Efficiency per pass in a recirculating system is far. less important than the totil elficiency of the systcm. 


\subsubsection{In-Place Testing of HEPA Filter Systems}

Experience has shown that a system containing HEPA filters. (and/or charcoal adsorbers) should be considered to have an unacceptable efficiency until an in-place test shows otherwise. Minor damage to a filter during installation, for example, may bypass significant quantities of uncleaned air through an operating filter system. Leakage has been found to be caused by a number of system defects, as well as by damage to or deterioration of filter units and media. Among the causes of leakage are damaged or improperly seated gaskets; rough or warped frame surfaces; clamps that are too loose, too few, or incorrectly positioned; lack of enough frame members; unwelded joints at corners and sides of frames; deterioration of filter media; damage to filter media during installation or other handling; and filters that sag because they were installed with pleats horizontal instead of vertical. ${ }^{1}$

In the past, the greatest effort in designing HEPA filter systems has been directed toward providing a system of adequate capacity. With some exceptions, less attention has been given to adequate structural and functional design of the system, and little consideration has been given to providing means for initially and periodically verifying the integrity of the installation. Recently, however, there has been an increasing awareness of the importance of in-place testing of high-efficiency filter systems. In addition to the initial in-place test, it is very important that each system be tested periodically and, also, after every filter change and whenever there is reason to suspect that efficiency has decreased.

In-place tests of filter systems are proof tests, with a twofold purpose. The total penetration of the system by the test aerosol is measured to establish either that the system has excessive leakage or that it meets the low leakage specification. If leakage is excessive, leaks are located by probing the system, and the defects are plugged or repaired as necessary until the system meets the specification.

In the in-place test used by the Oak Ridge National Laboratory, I-3 polydisperse DOP, produced by atomization with compressed air, is introduced into any convenient air intake that enables thorough mixing with 
the air stream ahead of the filter bank being tested. The concentration of the unfiltered aerosol is measured on a sample drawn from a point ahead of the filter bank and that of the aerosol in the filtered air is measured on a sample taken downstream of the filter bank. Frequently, the downstream sample is taken after the exhaust blower to insure a thoroughly mixed, representative sample. Use of this location is subject to the provision that blower-shaft-seal leakage must be negligible. Sampling lines should not be too long, since loss of sample by deposition within long lines can be severe. The 2-in.-thick charcoal beds used in commercial reactor practice are not expected to cause any bias in measurements, however. In in-place DOP tests at ORNL, no difference was found in the measured efficiency of a HEPA filter system when the same system was tested with and without approximately $21 / 4$ in. of charcoal (two $11 / 8$-in. beds in series) between the HEPA filters and the downstream sampling point. ${ }^{4}$ In another in-place DOP test, the measured efficiency for a charcoal bed alone was zero.

In calculating system.efficiency from the measured concentrations, the downstream concentration is divided by the upstream concentration; multiplication of the quotient by 100 gives the percentage penetration; this is subtracted from 100 to give the percentage removed by the system, which is referred to as the cfficiency of the system. To meet the specification of the in-place test at ORNL, the system must have a minimum efficiency of $99.95 \%$ for the removal of the polydisperse DOP. When an in-place tect shows an unarceptable efficiency, leakage paths can usually be detected readily by passing the aerosol into the system and probing the downstream side of the bank of filters and the filter mounting frame with a probe connected direct.ly ton the photometer.

A proposed standard based on the foregoing test method has been prepared. This proposed standard, "Efficiency 'l'esting of Air-Cleaning Systems Containing Devices for Remova.7. of Particulates," which was drafted by USASI Task Group N5.2.11, has been recommended for ballot action by the USSASI Nuclear Standards Board and approval as a USA Standard.

In-place testing of future installations can be simplified by careful planning in the design stage. Design of a filter installation should 
include builtin facilities for conducting in-place testing and access into the duct for sampling instrumentation.

The parallels in method, calculation, and expression of result between tests of new filters and tests of installed systems have caused some ambiguity and misinterpretation: Although the total penetration through the system is a measure of system efficiency, it is not a quantitative measure of the efficiency of the filters themselves, for two reasons. First, the system is usually tested with a compressed-air-generated polydisperse DOP aerosol with a number median diameter of about $0.7 \mu$, which is not intended as a substitute for the thermally generated monodisperse 0.3- $\mu$ DOP specified for testing new filters. Second, the total penetration through the system includes not only penetration through the filters but also penetration through. leaks that bypass the filters.

The differences between thermally generated and compressed-air-generated DOP have -no practical effect on the detection of leaks or on the efficiency of the system as determined by an in-place test. Most of the particles detected in a system downstream of the high-efficiency filter pass through holes or other continuous leakage paths that are larger by several orders of magnitude than the test particles.

\subsubsection{In-Place Testing of Adsorber Systems}

The charcoal impregnants used in the United States for reactor containment air-cleaning systems are specific for the removal of radioactive iodine from methyl iodide by isotopic exchange. Therefore, the efficiency of impregnated charcoals in the United States should be tested by an isotopic-exchange method, preferably with $\mathrm{CH}_{3}{ }^{131} \mathrm{I}$ (diluted with $\mathrm{CH}_{3}{ }^{127} \mathrm{I}$ ). A proof test for leaks with a nonradioactive gas (DuPont Freon-112) has been developed, however. In-place. leak testing of charcoal bcds in filter-adsorber systems, combined with tests of representative samples of charcoal from the beds with $\mathrm{CH}_{3}{ }^{13 I} \mathrm{I}$ and ${ }^{131} \mathrm{I}_{2}$ should be adequate. This combination would have the advantage of avoiding testing of the whole system with radioactive material.

At ORNL, charcoal beds are tested in place with small amounts of. ${ }^{1{ }^{1}} \mathrm{I}_{2}$ and $\mathrm{CH}_{3}{ }^{131} \mathrm{I}$ (in ${ }^{127} \mathrm{I}_{2}$ and $\mathrm{CH}_{3}{ }^{127} \mathrm{I}$ as carriers). ${ }^{5}$ This method is being widely adopted in the United States. 
At the Savannah River Plant, charcoal beds are routinely leak tested in place with DuPont Freon-112. 6,7 This method was developed by the Savannah River Laboratory under the sponsorship of the USAEC's Division of Operational Safety. The SRL leak tests are backed up by small-scale laboratory tests of the efficiency and capacity of the activated charcoal for removing molecular iodine by using small amounts of ${ }^{131} \mathrm{I}_{2}$. Testing of the efficiency of the beds for $\mathrm{CH}_{3}{ }^{131} \mathrm{I}$ removed is in progress at SRL. The SRL tests for molecular iodine removal have been standardized for general application. 6,7 .

\subsection{Operating Conditions}

Both the reliability of filter-adsorber systems under postulated accident conditions and the ability to test these systems in a manner that will assure their adequate performance and reliability under accident conditions are strongly affected by the location of the system and by economic considerations. Once-through filter-adsorber systems in secondary containment exhaust lines would function after an accident in an environment very similar to their normal environment. These systems, however, must have far greater integrity than that of ordinary air-conditioning systems and must be designed and constructed with builtin capabilities for adequate testing, inspection, and maintenance. Component efficiency is less critical in recirculating systems, but they must be designed, fabricated, installed, inspected, and maintained for high component integrity and high system integrity. In order to qualify as engineered safety features, recirculating systems must withstand the initial effects of the accident within the containment shell and must thereafter perform adequately and reliably in the hot, wet, high-pressure postaccident containment atmosphere. Recirculating systems must be rugged; this cannot be overemphasized.

6.2.1 Once-Through Systems in Secondary Containment Exhaust Lines

If the integrity of the containment shell is maintained after a major reactor accident, a once-through filter-adsorber system in the 
secondary containment exhaust line would be required to treat only a small volume of leakage from within the containment shell that would be highly diluted with air from the secondary containment structure atmosphere. The temperature, pressure, and humidity of the air passing through the system would be essentially ambient, and the fission-product loading would be very low compared with the postaccident loading on a recirculating filter-adsorber system within a containment shell.

An air-cleaning system of this type can be routinely tested in its entirety at ambient temperature, pressure, and humidity. Accident conditions would not differ materially from the test conditions, except for the fission-product loading. If the system is adequately engineered, constructed, and maintained, and it is frequently tested, it should prove reliable under accident conditions.

Except for a few special applications, such as those of the Indian Point. 1 and Oconee reactors, the secondary containment structures in which once-through filter-adsorber systems are provided as engineered safety features are the refueling buildings surrounding the pressuresuppression containments of typical boiling-water reactors. A containment shell leakage of $0.5 \%$ per day in a pressure-suppression system represents only about $0.1 \%$ of the design flow through the emergency aircleaning system in the secondary containment structure. Therefore, even if the leakage were $100 \%$ steam, it would not greatly increase the humidity of the air passing through the air-cleaning system.

Air to be cleaned by HEPA filters and charcoal adsorbers should be passed through moisture deentrainers, even in air-cleaning systems in the exhaust lines of secondary containment structures. For highest efficiency, the relative humidity of the air should be reduced to about $90 \%$ (preferably lower) before the air passes through filters and charcoal, particularly because of the deleterious effect of high humidity on the retention of methyl iodide by impregnated charcoals.

\subsubsection{Once-Through Systems in Containment Shell Exhaust Lines}

The protection afforded once-through filter-adsorber systems in the exhaust lines of secondary containment structures by the containment. 
shell and by dilution of the containment air that passes through them also applies to once-through filter-adsorber systems directly attached to the outside of the shell, if provision is made to dilute the atmosphere from within the containment shell with outside air before it passes through the air-cleaning system. If the containment atmosphere were allowed to pass through the air-cleaning system without dilution, the system would be subjected to an air-steam mixture which, under accident conditions, would be at about the same temperatures, pressures, and humidities as those to which recirculating filter-adsorber systems within the containment shell would be subjected.

\subsubsection{Recirculating Systems Within the Containment Shell}

Recirculating filter-adsorber systems within the containment shell must be able to perform reliably in the postaccident atmosphere within the containment shell, where temperature, pressure, humidity, and particulate concentration would be high. These systems must be protected from accident-produced pressure surges, shock waves, and missiles. They must also be protected from heavy loadings of moisture and particulate materials from the postaccident atmosphere. Prefilters are used to prevent clogging of HEPA filters by heavy particulate loadings. Moisture deentrainers are used to protect HEPA filters from moisture damage (see Sect. 4:2.1) and to reduce the amount of moisture that passes through charcoal beds.

\subsection{Performance of System Components}

\subsubsection{Effect of Humidity on Agglomerate Size and Filterability}

High relative humidity has been shown to decrease the size of agglomerates of the aerosols of uranium and stainless steel oxides by at least an order of magnitude and thus make them more difficult to filter. ${ }^{8-11}$ Moisture was shown to affect both size and shape of the agglomerates, probably by adsorption of water on particles and subsequent changes in surface tension forces. Particle sizes were measured indirectly with fibrous-filter analyzers ${ }^{12}$ and by electron-microscope examination of 
samples obtained with thermal precipitators. The dry agglomerates were chains, a few microns in length, of primary particles; at high aerosol concentrations there was a high proportion (almost 80\%) of agglomerates greater than $10 \mu$ in diameter. Aerosols generated in air at 80 to $90 \%$ relative humidity contained compact, approximately spherical agglomerates predominantly 2 to $3 \mu$ in diameter, and passage of either wet- or drygenerated aerosols through water reduced the size. to diameters of 0.1 to 1 H. 10 .

The possibility that the changes in size and shape of the agglomerates were the result of neutralization of electrical charges on the particles by water vapor was investigated. In one experiment, a sample of dry charged aerosol was not changed in appearance when neutralized by passage over a source of alpha activity; another sample was markedly changed in appearance by passage. through water, although water has little charge-neutralizing potential. It was therefore considered improbable that water changes the aerosol by charge neutralization..

The dry aerosol was filtered with a relatively high efficiency by filter packs of Dacron mats (fiber diameter about $11 \mu$ ) in series; 80 to 90\% was retained on the first two mats. Efficiency of the filter packs for the aerosol in: a humid atmosphere was much lower. Often over 50\% of. the aerosol.penetrated , smplet.e $\mathrm{gr}$ through a paols of 8 to 12 mats.. Il was concluded that roughing filters (prefilters) would not be efficient toward an aerosol of stainless steel-uranium oxides in a postaccident reactor atmosphere of high relative humidity, and there may be some danger of overluading HEPA filters in the air-cleaning system. ${ }^{10}$

The possibility that water affected the filtering action of the $11-\mu$ Dacron fibers was investigated by comparing the efficiencies of two filter packs, one of which had been prewetted by equilibration in a humid atmosphere, for 'removal of the dry aerosol. No essential difference in efficiency was found. In another test, no difference in efficiency for a wet aerosol was found between two filter packs, one of which was kept artificially dry by external trace heating. 
6.3.2 Use of Heater to Reduce Humidity in Charcoal Beds

A heater has been added to the design of the Browns Ferry system to insure low humidity in the charcoal beds. ${ }^{13}$ The Browns Ferry reactors are boiling-water reactors with pressure-suppression containment. ${ }^{4}$ Assuming perfect mixing, the humidity of air at ambient temp̄erature (about $80^{\circ} \mathrm{F}$ ) could be reduced from $100 \%$ to less than $70 \%$ by raising the temperature $10^{\circ} \mathrm{F}$. With the imperfect mixing expected in practice, a somewhat higher gross increase in temperature would probably be required to insure that this reduction in humidity was achieved across the whole face of the charcoal bed. The amount of heating necessary would depend on system configuration, flow patterns, and other parameters. In systems with relatively low volumetric flow rates, which are typical in pressuresuppression containment, heaters should be a practical and reliable means of maintaining an adequately low relative humidity.

\section{References}

I. E. C. Parrish and R. W. Schneider, Tests of High-Efficiency Filters and Filter Installations at ORNL, USAEC Report ORNL-3442, Oak Ridge National Laboratory, June 1963.

2. R. W. Schneider, In-Place Testing of High-Efficiency Filters, Nucl. Safety, 4(3): 56-58 (1963).

3. W. W. Goshorn and A. B. Fuller, Particulate Filter l'esting and Inspection Program, Nucl. Safety, 2(2): 37-38 (1960).

4. E. C. Parrish, Oak Ridge National Taboratory, personal communication, March 1968.

5. J. H. Swanks, In-Place Iodine Filter Testing, pp. 1092-1104 in Proceedings of Ninth AEC Air Cleaning Conference, Boston, Mass., September 13-16, 1966, USAEC Report CONF-660904, Vul. 2, January 1967.

6. W. S. Durant et al., Activity Confinement System of the Savannah River Plant Reactors, USAEC Report DP-1071, Savannah River Plant, August 1966 .

7. D. R. Muhlbaier, Standardized Nondestructive Test of Carbon Beds for Reactor Confinement Applications, Final Progress Report, February to June 1966, USAEC Report DP-1082, Savannah River Plant, July 1967. 
8. R. E. Adams et al., Filtration of Partịculate Aerosols Under Reactor Accident Conditions, USAEC Report ORNL-TM-1707, Oak Ridge National Laboratory, December 1966.

9. R. J. Davis et al., Filtration of Solid Aerosols, pp. 42-45 in ORNL Nuclear Safety Research and Development Program Bimonthly Report November-December 1967, USAEC Report ORNL-TM-2095, Oak Ridge National Laboratory, Febriary 1968. [Further information is presented in preceding bimonthly reports: ORNL-TM-2057 (September-October 1967), ORNL-TM-1986 (July-August), ORNL-TM-1913 (May-June), etc. ]

10. W. D. Yuille and R. E. Adams, Behavior of Oxide Aerosols of Uranium and Stainless Steel in Humid Atmospheres, USAEC Report ORNL-4198, Oak Ridge National Laboratory, January 1968.

11. W. D. Yuille and.R. E. Adams, Behavior of Aerosols in Fumid Atmo-. spheres, pp. 142-148 in Nuclear Safety Program Ann. Progr. Rept. Dec. 31, 1967, USAEC Report ORNL-4228, Oak Ridge National Laboratory, April 1968.

12. M. D. Silverman et al., Characterization of Radioactive Particulate Aerosols by the Fibrous Filter Analyzer, USAEC Report ORNL-4047, Oak Ridge National Laboratory, March 1967.

13. Tennessee Valley Authority, Design and Analysis Report for Browns Ferry Nuclear Power Station, Amendment H 9-1, Docket Nos. 50-259 and $50-260$.

14. Tennessee Valley Authority, Design and Analysis Report for Browns Ferry Nuclear Power Station Units 1 and 2, Dockets 50-259 and -260 . 


\section{AIR CLEANUP POTENTIAL OF. CHEMICAL SPRAY SYSTEMS}

An extensive research and development program on spray systems is. being coordinated at ORNL. This program includes searches for better solutions, single-drop parameter studies, radiolytic decomposition and hydrogen production investigations, corrosion tests, and scaleup and modeling experiments on both sprays and pressure-suppression systems. Almost all water-cooled power reactors have provision for cooling the containment atmosphere in the event of a loss-of-coolant accident by spraying cold water directly into the containment shell. Spray cooling systems, adopted for iodine removal by a chemical additive, are being investigated as means of postaccident containment atmosphere cleanup that may be much more reliable than any economically feasible recirculating filter-adsorber systems. The design and testing of chemical spray systems are discussed briefly in section 3.4.2.

In pressure-suppression containment systems, which have a low ratio of free volume to water volume, plain water sprays can, in theory, significantly reduce the iodine concentration in the containment atmosphere. This capability would be lower in pressure containment systems. For more efficient removal in either type of containment, however, a chemical may be added to the spray water. The chemical solution would have to be analyzed periodically to be sure no degradation or precipitation had taken place. The addition of either borated basic ( $\mathrm{pH}$, 9.0 ) sodium thiosulfate $\left(\mathrm{Na}_{2} \mathrm{~S}_{2} \mathrm{O}_{3}\right)$ or borated sodium hydroxide $(\mathrm{NaOH})$ to the containment spray cooling water has been proposed for or included in the design of several reactors with pressure containment. The use of hydrazine $\left(\mathrm{N}_{2} \mathrm{H}_{4}\right)$ for methyl iodide removal has been investigated, ${ }^{l}$ but the toxicity of hydrazine, its possible radiolytic decomposition to form hydrogen, and the potential explosion hazard of its vapor preclude its use in reactor spray solutions.

A program at ORIL was established to make a thorough investigutiun of the varlous solutions suggested for use in a spray system from the consideration of efficiency in removing contaminants. ${ }^{2,3}$ The major portion of the effort has been devoted to collecting information about spray

oyotcme proposed for use by industry in the immediate future. Close 
liaison with industry has been maintained so that the data generated are directly applicable to systems now being designed. The long-range objective of the program is to evaluate a large number of spray-solution additives and their characteristics so that the results of the program can be applied to future plants with different requirements. The gas-liquid systems involved are being investigated to evaluate the degree of removal of fission products that may be expected during the operation of a spray system.

In laboratory-scale investigations a large number of solutions are being examined for use as additives to the spray. The next step is to use a wind tunnel to determine mass transfer from a contaminated gas stream into a single drop of solution under various conditions. Engineering-scale tests of the solutions are then made in the Nuclear safety Pilot Plant at ORNL and the Containment Systems Experiment at Battel'le's Pacific Northwest Laboratory. In addition, corrosion-testing facilities are now being used to determine compatibility of the various solutions with the reactor materials they would contact. The thermal and radiation stability of the solutions is a matter of concern, and the latter tests have revealed that most solutions release more hydrogen than is generated in the design-basis accident from the metal-water reaction.

\subsection{Screening of Potential Additives}

In the spray-solution search at. $\mathrm{ORNL}^{4-6}$ a gas-titration method is employed for experimentally determining the capacity of aqueous solutions for removal of iodine from air streams. The onset of escape of measurable iodine is found to be dependent on the rate of transfer from gas to solution and hence upon efficiency of the dispersion and the contact time. The capacity, expressed as a distribution coefficient, is linear in the amount of reactive additive (thiosulfate or base) used.

The first step in the investigation of the various possible spray solutions involves small laboratory experiments in which a large number, of solutions can be evaluated quickly before being tested in larger facilities. The principal objectives originally set for this work were (1) to develop a method and technique for measuring distribution 
coefficients of $\mathrm{I}_{2}$ and $\mathrm{CH}_{3} \mathrm{I}$ between air and aqueous solutions at equilibrium, (2) to use the method to screen potential additives for spray solutions, (3) to study rates of approach to equilibrium distribution, and $\left(l_{1}\right)$ to study the effects of other variables (such as side reactions with air or other gases, temperature, and additive concentrations) on relative scrubbing efficiencies for additives.

The carrier gas is bubbled through scrubber solutions. In most. studies to date, nitrogen has been used as the carrier gas in order to limit the number of experimental variables. Some work has been done on the effects of varying the cover gas, particularly the possible regeneration of fixed iodine by air oxidation.

\subsubsection{Theoretical Examination of Iodine-Water Partition Coefficients}

Examination of the various reactions of iodine in water leads to the selection of four fast reactions that control the equilibrium between elemental iodine and its hydrolysis products. ${ }^{7}$ On the assumption that elemental iodine is the only volatile species, water-gas phase partition coefficients have been calculated from the equilibrium constants. At $25^{\circ} \mathrm{C}$ the value increases from a minimum of 83 at high iodine concentrations and low $\mathrm{pH}$ to values in excess of 10,000 at high $\mathrm{pH}$ and low iodine concentrations. The values for $100^{\circ} \mathrm{C}$ are smaller than the $25^{\circ} \mathrm{C}$ values at high iodine concentration but increase more rapidly as the $\mathrm{pH}$ is raised and the iodine concentration lowered. The slow reaction leading to iodate formation is found to be of importance only at $\mathrm{pH}$ values greater than 7, both on equilibrium and rate grounds.

The effects of traces of oxidizing and reducing agents have been assessed on the basis of the redox potential of the final solution. For each pH value there j.s a corresponting valiue of the redox potential that gives minimum values of the partition coefficient at all iodine concentrations. Departures from this optimum in either direction cause a marked increase. This effect is particularly important with very dilute iodine solutions and may explain the anomalous experimental values in the literature. 
The study has indicated areas where experimental data are sparse. In particular, the equilibrium constants of $\dot{a}$ number of reactions are not well established at temperatures other than $25^{\circ} \mathrm{C}$, and the partition coefficient of HIO in water is unknown.

In this treatment, account has been taken of all the known reactions of elemental iodine with water over a wide range of $\mathrm{pH}$. Should there be further reactions taking place at low iodine concentrations, as has been suggested, these will almost certainly yield iodine species more water soluble than iodine itself and lead to partition coefficients larger than those calculated. Errors due to omission of activity coefficient corrections, which will be small at the iodine concentrations of practical interest, will also have the same effect.

The error in the values calculated for $100^{\circ} \mathrm{C}$ is likely to be greater than the error in those calculated for $25^{\circ} \mathrm{C}$ because of the extrapolation necessary to estimate values of the equilibrium constants at the higher temperature. Experimental confirmation is clearly required.

Oxidizing and reducing agents always increase the partition coefficient above the values calculated in their absence, so calculations based on the latter values of the amount of elemental iodine remaining in the gas phase following a reactor accident will generally err on the pessimistic side unless the partition coefficient of hypoiodous acid should turn out to be unexpectedly small. Account must also be taken of iodine present in particulate form or as volatile compounds, such as methyl iodide.

\subsubsection{Measurement of Distribution Coefficients for Various Additives}

The initial work ${ }^{4}$ consisted principally of developing a technique for studying the partitioning process under flow conditions (gas through liquid) and comparing $\mathrm{Na}_{2} \mathrm{~S}_{2} \mathrm{O}_{3}$ and $\mathrm{NaOH}$ by means of the procedures developed. In order to evaluate additives as chemical scrubbers, a thorough study was started not only of the additives themselves but of solutions containing the products of reaction of iodine with these additives. Distribution coefficients and elapsed times before first observation of 
iodine penetration are shown in Table 7.1 for the solutions initially investigated at $25^{\circ} \mathrm{C}$ and a gas-phase iodine concentration of about $10^{-5} \mathrm{M}$. With respect to the work completed in the first half of the program, the following conclusions were drawn. Distribution coefficients for water agree reasonably well with the lowest literature values available 78 and are reproducible to within $\pm 2 \%$. Capacity increases sharply with addition of substances reactive toward iodine. There is little difference between thiosulfate and base in this respect. Both exceed their stoichiometrically predicted capacity. Extra capacity is shown to result from the reaction with iodide ion to produce triiodide ion. Boric acid increases the capacity of water for iodine, and excess boric acid destroys the capacity of the base. The time at which iodine begins to escape

Table 7.1. Iodine Distribution Coefficients and Initial Penetration Times for Various Test Solutions

\begin{tabular}{|c|c|c|c|}
\hline Test Solution & $\begin{array}{l}\text { Additive } \\
\text { Concentration } \\
\text { (molar, except } \\
\text { as noted) }\end{array}$ & $\begin{array}{l}\mathrm{K}_{\mathrm{d}}^{\prime} \\
\text { Distribution } \\
\text { Coefficient }\end{array}$ & $\begin{array}{l}t_{0} \text {, Initial } \\
\text { Penetration } \\
\text { Time } \\
\text { (sec) }\end{array}$ \\
\hline Pure $\mathrm{H}_{2} \mathrm{O}$ & & 92. & 180 \\
\hline $\mathrm{H}_{3} \mathrm{BO}_{3}$ in $\mathrm{H}_{2} \mathrm{O}$ & 3000 ppm B & 85 & 165 \\
\hline $\mathrm{Na}_{2} \mathrm{~S}_{2} \mathrm{O}_{3}$ in $\mathrm{H}_{2} \mathrm{O}$ & $\begin{array}{l}0.921 \times 10^{-3} \\
2.31 \times 10^{-3} \\
4.62 \times 10^{-3}\end{array}$ & $\begin{array}{l}150 \\
250 \\
380\end{array}$ & $\begin{array}{r}551 \\
1029 \\
1883\end{array}$ \\
\hline $\mathrm{Na}_{2} \mathrm{~S}_{2} \mathrm{O}_{3}$ in standard $\mathrm{H}_{3} \mathrm{BO}_{3}$ & $2.31 \times 10^{-3}$ & 237 & 1022 \\
\hline $\mathrm{NaOH}$ in $\mathrm{I}_{2} \mathrm{O}$ & $\begin{array}{l}1.012 \times 10^{-3} \\
2.52 \times 10^{-3} \\
5.05 \times 10^{-3}\end{array}$ & $\begin{array}{l}155 \\
250 \\
400\end{array}$ & $\begin{array}{r}562 \\
996 \\
1784\end{array}$ \\
\hline $\mathrm{NaOH}$ in standard $\mathrm{H}_{3} \mathrm{BO}_{3}$ & $2.5 .2 \times 10^{-3}$ & 83 & 218 \\
\hline $\mathrm{Na}_{2} \mathrm{~S}_{2} \mathrm{O}_{3}$ in $\mathrm{H}_{2} \mathrm{O}^{\mathrm{b}}$ & $2.31 \times 10^{-3}$ & 249 & 404 \\
\hline $\mathrm{KI}$ in $\mathrm{H}_{2} \mathrm{O}$ & $\sim 0.1$ & 145 & 253 \\
\hline $\mathrm{KI}$ in standard $\mathrm{H}_{3} \mathrm{BO}_{3}$ & -0.1 & 157 & 230 \\
\hline
\end{tabular}


depends on the way the scrubbing is done (bubbling rate, dispersing efficiency, etc.), but capacities calculated by extrapolation to infinite time are independent of these variables.

7.1.3 Work on Additional Compounds, Reaction Products, and Temperature Effects

Work on the distribution of iodine between nitrogen streams and aqueous solutions has been extended ${ }^{5,6}$ in the following areas: survey of potential additives, study of capacities of primary reaction products for principal additives, and examination of the temperature effects on the capacity coefficient for principal additives. Because of some confusion that surrounded previous reference to $K_{d}^{\prime}$ as a "distribution coefficient," $K_{a}^{\prime}$ is now referred to as a "capacity coefficient," since all dissolved iodine species are included in the solution concentration term.

Table 7.2 lists values of $K_{d}^{\prime}$ at $25^{\circ} \mathrm{C}$ for the second group of compounds surveyed. Data on water, sodium thiosulfate, and sodium hydroxide from previous work are included for comparison. Piperidine, morpholine, and resorcinol produced solid products. The high capacity of $\mathrm{N}_{2} \mathrm{H}_{4}$

Table 7.2. Survey of Potential Additives to Sprays (or Pressure-Suppression Pools)

\begin{tabular}{lcc}
\hline \multicolumn{1}{c}{ Additive } & $\begin{array}{c}\text { Concentration } \\
\text { (molar, except } \\
\text { as noted })\end{array}$ & $\mathrm{K}_{\mathrm{d}}^{\prime}$ at $25^{\circ} \mathrm{C}$ \\
\hline $\mathrm{H}_{2} \mathrm{O}$ & & 92 \\
$\mathrm{Na}_{2} \mathrm{~S}_{2} \mathrm{O}_{3}$ & $2.31 \times 10^{-3}$ & 250 \\
$\mathrm{NaOH}$ & $2.52 \times 10^{-3}$ & 250 \\
$\mathrm{KOH}$ & $2.39 \times 10^{-3}$ & 202 \\
Piperidine & $\sim 2.5 \times 10^{-3}$ & 369 \\
Morpholine & $\sim 2.5 \times 10^{-3}$ & 277 \\
$\mathrm{~N}_{2} \mathrm{H}_{4}$ & $2.32 \times 10^{-3}$ & 618 \\
Ethylene glycol & $10 \mathrm{vol} \%$ & 151 \\
& $45 . \mathrm{Vol} \%$ & 428 \\
Resorcinol & $\sim 2.5 \times 10^{-3}$ & 728 \\
\hline
\end{tabular}


(hydrazine) was consistent with the quantitative reaction expected. The high affinities of ethylene glycol solutions are consistent with solubility data, ${ }^{7}$ which suggest extripemely large $K_{d}^{\prime}$ values for high concentrations.

A quantitative reaction model ${ }^{9}$ used to interpret thiosulfate and base capacities attributed additional capacity to the products of the initial reactions. Several compounds were studied to check the validity of this assumption, with the results given in Table 7.3 .

Potassium iodate $\left(\mathrm{KIO}_{3}\right)$, as expected, shows only a very small salting effect. The surprising effect of tetrathionate may confirm suggestions ${ }^{10}$ that iodine reacts slowly with $\mathrm{S}_{4} \mathrm{O}_{6}^{2-}$. The method of analysis used in these studies (extrapolation to infinite time) should reflect this contribution even if the reaction is quite slow. The significant capacity of $\mathrm{I}^{-}$was confirmed by the result for NaI. The contribution of $\mathrm{I}^{-}$is consistent with the solubility datall and with the efficiency required to explain the $\mathrm{S}_{2} \mathrm{O}_{3}^{2-}$ and $\mathrm{OH}^{-}$results. Sodium sulfate $\left(\mathrm{Na}_{2} \mathrm{SO}_{4}\right)$, used as a model compound for "unreactive sodium thiosulfate," behaves similarly. This salting-out behavior agrees well with solubility data.ll

Table 7.4 shows the variation of $K_{d}^{\prime}$ of some of the more important systems with temperature. Although only a very limited amount of data has been collected so far, it seems that there is. a significant increase

Table 7.3. Secondary Capacities of Additives

\begin{tabular}{lcc}
\hline Additive & $\begin{array}{c}\text { Concentration } \\
(\text { molar) }\end{array}$ & $\mathrm{K}_{\mathrm{d}}^{\prime}$ at $25^{\circ} \mathrm{C}$ \\
\hline $\mathrm{KIO}_{3}$ & 0.1 & 110 \\
$\mathrm{Na}_{2} \mathrm{~S}_{4} \mathrm{O}_{6}$ & 0.1 & 348 \\
$\mathrm{NaL}$ & $2.32 \times 10^{-3}$ & 179 \\
$\mathrm{Na}_{2} \mathrm{SO}_{4}$ & 0.1 & 86 \\
& 0.2 & 80 \\
& 0.3 & 73 \\
& 0.4 & 67. \\
\hline
\end{tabular}


Table 7.4. Variation of $\mathrm{K}_{\mathrm{d}}^{\prime}$ with Temperature

\begin{tabular}{|c|c|c|c|c|}
\hline \multirow{2}{*}{ Additive } & \multirow{2}{*}{$\begin{array}{l}\text { Concentration } \\
\text { (molar, except } \\
\text { as noted) }\end{array}$} & \multicolumn{3}{|c|}{ 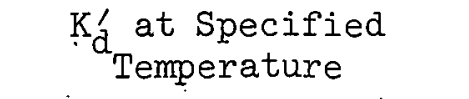 } \\
\hline & & $25^{\circ} \mathrm{C}$ & $45^{\circ} \mathrm{C}$ & $66.2^{\circ} \mathrm{C}$ \\
\hline $\mathrm{H}_{2} \mathrm{O}$ & . & 92 & 87 & 72 \\
\hline $\mathrm{H}_{3} \mathrm{BO}_{3}$ & $3000 \mathrm{ppm} \mathrm{B}$ & 85 & .72 & \\
\hline $\mathrm{Na}_{2} \mathrm{~S}_{2} \mathrm{O}_{3}$ & $2.31 \times 10^{-3}$ & 250 & 288 & 345 \\
\hline $\mathrm{NaOH}$ & $2.53 \times 10^{-3}$ & 250 & 219 & 155 \\
\hline $\mathrm{Na}_{2} \mathrm{~S}_{2} \mathrm{O}_{3}-\mathrm{NaOH}$ & $\begin{array}{c}2.42 \times 10^{-3} \text { (total: } \\
\text { in } 50: 50 \text { mixture) }\end{array}$ & 261 & & 221 \\
\hline
\end{tabular}

in the iodine capacity of $\mathrm{S}_{2} \mathrm{O}_{3}^{2-}$ but a decrease for $\mathrm{OH}^{-}$with increasing temperature. This effect will be examined in more detail.

Data were also obtained for aqueous solutions of hydrazine, various amines, and ethylene glycol as primary additives. These include compounds similar in structure to those already studied and a variety of other systems. ${ }^{6}$ The data here were collected at $25^{\circ} \mathrm{C}$ and an iodine gas-phase concentration of $1.20 \times 10^{-5}$ mole/liter. In Table 7.5, $\mathrm{K}_{\mathrm{d}}^{\prime \prime} \mathrm{s}$ are giver for some of the acids, bases, and salts examined. The data for the nonreactive salts are in good agreement with solubility data.11 Iithium hydroxide has a greater iodine capacity than some of the other bases investigated. This increase might be explained by the "structure making" property of the lithium ion. 12

Table 7.6 contains data for some solvent additives. These data are also in agreement with solubility data in those cases where data are available. The $\mathrm{K}_{\mathrm{d}}^{\prime}$ 's reported for the two glycol systems are not very large, but the solubility of iodine increases exponentially with increasing glycol concentration and the $\mathrm{K}_{\mathrm{d}}^{\prime \prime}$ 's would increase accordingly.

Some compounds that react with iodine are listed in Table 7.7. The extremely large value for pyrrole is supported by the fact that the tet- . rahalogenated product is reportedly formed if excess halogen is present. ${ }^{13}$ 
Table 7.5. Iodine-Capacity Coefficients for the Acids, Bases, and Salts Examined

\begin{tabular}{lcc}
\hline \multicolumn{1}{c}{ Compound } & Concentration (molar) & $\mathrm{K}_{\mathrm{d}}^{\prime}$ \\
\hline $\mathrm{NaNO}_{3}$ & $9.56 \times 10^{-2}$ & 103 \\
$\mathrm{CH}_{3} \mathrm{COOH}$ & $2.56 \times 10^{-3}$ & 109 \\
$\mathrm{NaClO}_{3}$ & $9.8 \times 10^{-2}$ & $11 ?$ \\
$\mathrm{H}_{2} \mathrm{SO}_{4}$ & $2.252 \times 10^{-3}$ & 117 \\
$\mathrm{Na}_{3} \mathrm{C}_{6} \mathrm{H}_{5} \mathrm{O}_{7}$ & $2.41 \times 10^{-3}$ & 122 \\
$\mathrm{NH}_{4} \mathrm{OH}$ & $1.775 \times 10^{-4}$ & 131 \\
$\mathrm{LiOH}$ & $2.755 \times 10^{-3}$ & 313 \\
$\mathrm{Na}_{2} \mathrm{~B}_{4} \mathrm{O}_{7} \cdot 1 \mathrm{OH}_{2} \mathrm{O}$ & 0.1 & 874 \\
\hline
\end{tabular}

Table 7.6. Iódine-Capacity Coefficients for Solvent Additives

\begin{tabular}{lcc}
\hline \multicolumn{1}{c}{ Compound } & $\begin{array}{c}\text { Concentration } \\
(\text { vol } \%)\end{array}$ & $\mathrm{K}_{\mathrm{d}}^{\prime}$ \\
\hline Glycerine & 30 & 173 \\
Ethyl alcohol & 30 & 203 \\
Dipropylene glycol & 20 & 215 \\
Dioxane & 20 & 235 \\
Dimethylformide & 20 & 278 \\
Triethylene glycul & 30 & 342 \\
\hline
\end{tabular}

As shown in Table 7.7 , amines react with iodine and yield substantial $\mathrm{K}_{\mathrm{d}}^{\prime}$ values, but in most cases the solid product is undesirable.

since sulfides and hydrazine react with iodine, compounds containing one or both of these components were investigated. The data collected for these systems are given in Table 7.8. Sodium thiosulfate and hydrazine were included for comparison. The literature indicates that the 
Table 7.7. Capacity Coefficients of Compounds That React with Iodine

\begin{tabular}{|c|c|c|}
\hline Compound & $\begin{array}{c}\text { Concentration } \\
\text { (molar) }\end{array}$ & $\mathrm{K}_{\mathrm{d}}^{\prime}$ \\
\hline & $\times 10^{-3}$ & \\
\hline Creatinine & 2.52 & 114 \\
\hline Glycine & 2.37 & 125 \\
\hline Pyridine & 2.5 & $197^{a}$ \\
\hline $\mathrm{AgNO}_{3}$ & 2.255 & $242^{a}$ \\
\hline 4-Aminopyridine & 2.5 & $391^{\mathrm{a}}$ \\
\hline Quinoline & 2.5 & $450^{\mathrm{a}}$ \\
\hline Piperazine & 2.5 & $517^{a}$ \\
\hline 1,4-Trihydroxybenzene & 2.32 & $817^{\mathrm{a}}$ \\
\hline Pyrrole & 2.5 & $1100^{\mathrm{a}}$ \\
\hline
\end{tabular}

Table 7.8. Results of Methyl Iodide Removal Runs in NSPP Spray nozzles: three No. 7G3 from Spraying Sys tems Company

\begin{tabular}{|c|c|c|c|c|}
\hline \multirow{2}{*}{$\begin{array}{l}\text { Run } \\
\text { No. }\end{array}$} & \multirow[b]{2}{*}{ Solution } & \multirow{2}{*}{$\begin{array}{l}\text { Initial MCV } \\
\text { Temperature } \\
\left({ }^{\circ} \mathrm{C}\right)\end{array}$} & \multicolumn{2}{|c|}{ Half-Life (min) } \\
\hline & & & $\begin{array}{l}\text { From MCV } \\
\text { Gamma Data }\end{array}$ & $\begin{array}{l}\text { From Iodide } \\
\text { Balance }\end{array}$ \\
\hline $39^{a}$ & Borated $\mathrm{NaOH}^{\mathrm{b}}$ & 130 & 42 & 52 \\
\hline $40^{a}$ & Borated alkaline thiosulfate ${ }^{c}$ & 30 & 87 & 25 \\
\hline $41^{a}$ & Borated $\mathrm{NaOH}$ & 30 & 360 & 59 \\
\hline 43 & Borated $\mathrm{NaOH}^{\mathrm{b}}$, d & 30 & Infinity. & (e) \\
\hline $44 \mathrm{f}$ & $\begin{array}{l}\text { Borated alkaline thiosulfate } \\
\text { with surfactant }\end{array}$ & 130 & 35 & $(g)$ \\
\hline
\end{tabular}

In runs 39,40 , and 41 there was a short half-life when the sprays started that was attributed to thermal decomposition of the methyl iodide.

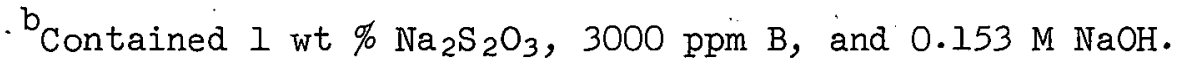

${ }^{\mathrm{C}}$ Contained $3000 \mathrm{ppm} \mathrm{B}$ and $0.153 \mathrm{M} \cdot \mathrm{NaOH}$.

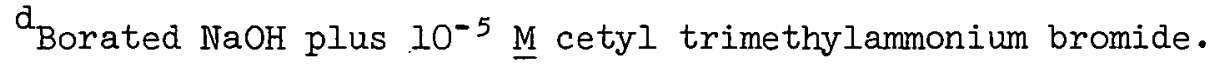

everall decontamination factor was 1.03 in $3 \mathrm{hr}$.

' $f$ The interior of the MCV was illuminated by four $150-\mathrm{w}$ incandescent lamps during the last $2 \mathrm{hr}$ of the run.

g Analysis incomplete. 
reactions for thiourea and thiosemicarbazide with iodine are the following: 14

$$
\begin{gathered}
\mathrm{H}_{2} \mathrm{NCSNH}_{2}+4 \mathrm{I}_{2}+4 \mathrm{H}_{2} \mathrm{O} \rightarrow \mathrm{H}_{2} \mathrm{NCN}+\mathrm{H}_{2} \mathrm{SO}_{4}+8 \mathrm{HI}, \\
\mathrm{H}_{2} \mathrm{NCSNHNH}_{2}+6 \mathrm{I}_{2}+5 \mathrm{H}_{2} \mathrm{O} \rightarrow \mathrm{N}_{2}+\mathrm{HCNO}+12 \mathrm{HI}^{\circ}+\mathrm{H}_{2} \mathrm{SO}_{4} .
\end{gathered}
$$

In spite of the fact that the above reactions are used for a quantitative determination of these compounds, the data in Table 7.8 illustrate that the system is not quantitative under these conditions. However, the reactions may be slow at the temperature used, and the equilibrium may be suppressed by the large quantities of acid produced. Therefore it is planned to investigate the temperature and $\mathrm{pH}$ dependence.

The data confirm that the addition of an $\mathrm{s}^{2-}$ or hydrazine function. in a molecule produces $K_{d}^{\prime}$ values comparable with those of $\mathrm{S}^{2-}$ ion and $\mathrm{NH}_{2}-\mathrm{NH}_{2}$ themselves. It may well be that some compound containing these structures will be found to have storage and performance properties superior to those of the parent compounds. Therefore, it was suggested that pyrolytic and radiolytic stability be investigated for some of these compounds and that, since thiourea and sodium thiocyanate are common chemicals, they might very well be preferable to sodium thiosulfate, even on an economic basis.

\subsection{Uptake of $\mathrm{I}_{2}$ and $\mathrm{CH}_{3} \mathrm{I}$ by Single Drops of Water Solution Suspended in a Wind Tunnel}

The mass transport of methyl iodide into a water drop is being detcrmined at ORNL by suspending drops of various solutions in a wind tunnel through which an air stream containing methyl iodide is directed.15-17 Specific emphasis has been focused on the role of additives on both the k.i.netics and thermodynamics of methyl iodide removal by aqueous solutions. At low concentrations ( $\sim .2$ wt $\%$ ) such diverse additives as $\mathrm{NH}_{2}-\mathrm{NH}_{2}$, $\left(\mathrm{NH}_{4}\right)_{2} \mathrm{~S}$, and $\mathrm{Na}_{2} \mathrm{~S}_{2} \mathrm{O}_{3}$ enhance the mass transport of $\mathrm{CH}_{3} \mathrm{I}$ in a common manner, with the differences in the specific effectiveness becoming apparent at higher additive concentrations. Drop size studies indicate that the $\mathrm{CH}_{3} \mathrm{I}$ transport process is controlled by a combination of surface effects, a. well as the circulation of the solution in the interior of the drop. 
There is a pronounced effect of $\mathrm{pH}$ and relative humidity on both the mass-transport coefficients and the solution affinity for methyl iodide in $\mathrm{Na}_{2} \mathrm{~S}_{2} \mathrm{O}_{3}$. The decrease in the mass-transport values $\left(\sim 5 \times 10^{-3} \mathrm{~cm} / \mathrm{sec}\right)$ at about $25^{\circ} \mathrm{C}$ on the acidic side is characterized by an activation energy of approximately 10,000 cal/mole. At a pH of 7 or higher, the transport coefficients $\left(3.6 \times 10^{-2} \mathrm{~cm} / \mathrm{sec}\right)$ are approximately independent of temperature. The mass transport of $\mathrm{CH}_{3} \mathrm{I}$ in water appears to be accelerated by photolysis; that is

$$
\mathrm{CH}_{3} \mathrm{I}+\gamma+\mathrm{H}_{2} \mathrm{O} \rightarrow \mathrm{CH}_{3} \mathrm{OH}+\mathrm{H}+\mathrm{I}^{\mathrm{O}} \text {. }
$$

The efficiency of $\mathrm{CH}_{3} \mathrm{I}$ removal by aqueous spray systems can be enhanced by buffering the additive solution in order to maintain basicity.

\subsection{Spray Tests in the Nuclear Safety Pilot Plant}

Engineering-scale experiments on the performance of sprays are carried out in the Nuclear Safety Pilot Plant at ORNL to demonstrate the performance under simulated accident conditions of solutions for the removal of molecular iodine $\left(\mathrm{I}_{2}\right)$ and methyl iodide $\left(\mathrm{CH}_{3} \mathrm{I}\right)$ and equipment that might be used in reactor containment buildings.18,19 Results of tests. of various solutions in the NSPP exhibit no significant difference in the half-life for iodine removal - the half-life is small in all cases and indicates that the solubility of iodine in water predominates. On the other hand, methyl iodide is much more difficult to remove. Table 7.8 summarizes experimental results of several runs. It is concluded that there is no.significant effect associated with the spray being at a higher temperature than the containment vessel. The fact that contact with metal surfaces at temperatures in the range 130 to $175^{\circ} \mathrm{C}$ was sufficient to decompose a significant part of the methyl iodide indicates a possible natural mechanism for methyl iodide removal.

In one run, 43, a borated sodium hydroxide at. room temperature was used as the spray solution for removing methyl iodide from the model containment vessel (MCV) atmosphere. During this test the inside of the vessel was illuminated (four 150-w incandescent lamps) during the last. 2 hr of spraying to test the hypothesis that a photocatalyzed reaction 
may be taking place. However, the gamma data indicated no measurable reduction in airborne iodine. The work of Schwendiman and his associates ${ }^{1}$ indicates that the reaction between hydroxyl ion and methyl iodide should be expected to be very slow at room temperature, especially when the hydroxyl ion concentration is suppressed by the boric acid in the spray solution.

An alkaline borated thiosulfate solution containing $10^{-5}$ moles/liter of a surfactant proposed by Soldano and Ward ${ }^{20}$ was tested (run 44). The MCV atmosphere was an air-steam mixture at $130^{\circ} \mathrm{C}$ and $45 \mathrm{psig}$ at the start of the run, and the temperature decreased to $120^{\circ} \mathrm{C}$ during the run. The gamma data indicate that elemental iodine was present when the sprays were turned on because of a very rapid removal half-life for the first 20 to $30 \mathrm{sec}$, but it was in quantities substantially less than in runs 39, 40, and 4l. The half-life for methyl iodide removal was $35 \mathrm{~min}$, and the overall decontamination factor was 50. The solution containing surfactant appeared to perform appreciably better than alkaline borated thiosulfate alone.

\subsection{Analytical Models of Iodine Removal by Sprays}

In order to assist in planning experiments and in interpreting the results, theoretical studies and computer program development are also being carried out at ORNL. ${ }^{19}$ The first model developed was an extension of that proposed by Griffiths ${ }^{3}$ for gas-film-controlled absorption. For this model it is assumed that all drops are the same size and are all falling at their terminal velocity. A program was written for the CDC 1604 to calculate (1) the physical properties of the air-steam atmosphere expected to result from a loss-of-coolant accident, (2) the terminal velocities of drops in that atmosphere, and (3) the mass-transfer coefficients.

Later it was also desired to know the liquid distribution from a particular nozzle and how this distribution might be affected by the containment vessel atmosphere conditions. A computer program was then written to calculate drop trajectories. For this program, a hollow-cone pressure nozzle was assumed. In a nozzle of this type, the liquid is 
given rotational motion in a swirl chamber and then leaves the nozzle through an orifice. The center of the orifice is occupied by an air core, which normally fills 60 to $80 \%$ of the orifice diameter. The liquid flows through an annulus outside the air core and forms a conical sheet that breaks into drops a short distance from the nozzle.

The computer program was tested on data from the NSPP by using spraydrop size data measured by Westinghouse Electric Corporation.21 It was also tested against data from the first spray performance test in the $\mathrm{CSE}^{22}$ and data from tests at NRTS reported by. Maekawa and his associates. 23. For the CSE, the predicted half-life was $202 \mathrm{sec}$ and the observed half-life was $310 \mathrm{sec}$. Predicted and observed results for the NSPP are compared in Table 7.9 and for the experiments of Maekawa and his associates in Table 7.10. The agreement is fair to good, except in the case

Table 7.9. Comparison of Experimental Results in NSPP with Predictions of NSPP Model

\begin{tabular}{|c|c|c|c|c|}
\hline \multirow{2}{*}{$\begin{array}{l}\text { Run } \\
\text { No. }\end{array}$} & \multirow{2}{*}{$\begin{array}{l}\text { Flow } \\
\text { (gpm) }\end{array}$} & \multirow{2}{*}{$\begin{array}{c}\text { Mean Drop } \\
\text { Diameter } \\
(\mu)\end{array}$} & \multicolumn{2}{|c|}{ Half-Life (sec) } \\
\hline & & & Predicted & Observed \\
\hline 21 & 0.57 & 100 & 3 & $37-67$ \\
\hline 22 & 0.52 & 100 & 3 & $35-40$ \\
\hline 26 & 10.3 & 900 & 98 & $31-58$ \\
\hline $27^{\circ}$ & 9.9 & 920 & 107 & $48-57$ \\
\hline 28 & 10.1 & 910 & 102 & $44-69$ \\
\hline 30 & 15.5 & 670 & 36 & $24-69$ \\
\hline 31 & 15.3 & 680 & 37 & $32-179$ \\
\hline 32 & 10.3 & 900 & 98 & $40-92$ \\
\hline 33 & 10.6 & 890 & 94 & $21-136$ \\
\hline
\end{tabular}

Extremes of observed half-lives were calculated from three or more of the following: (1) MCV gamma-ray intensity, (2) samples of spray solution. versus time, (3) gas samples before and after spraying, (4) total activity picked up by solution versus activity left in gas, as shown by purge samples, and (5) rate of gamma buildup in solution in bottom of vessel. 
Table 7.10. Comparison of Results of Maekawa and his Associates ${ }^{23}$ with Predictions of NSPP Modela

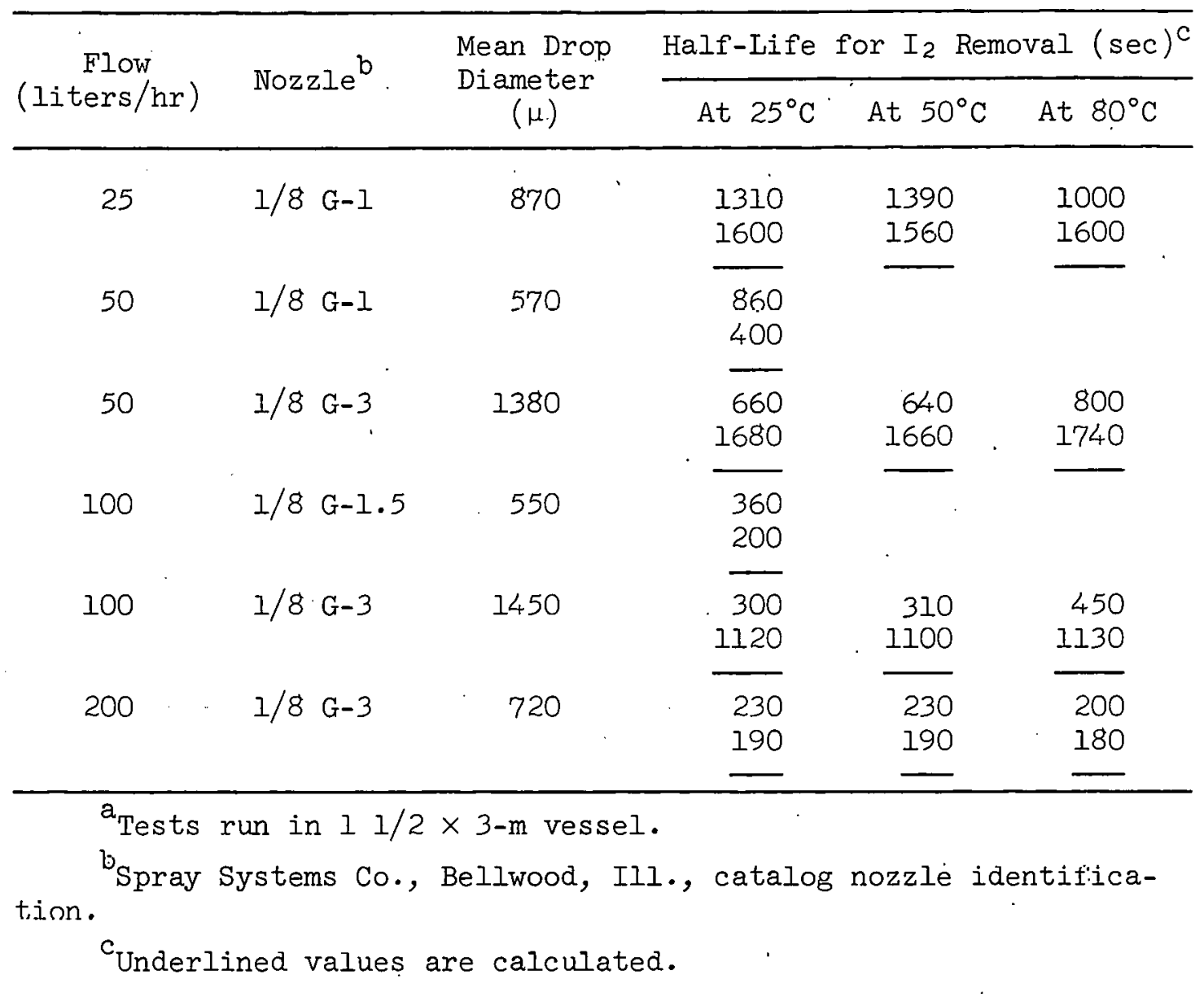

of the NSPP low-flow experiments, in which there were leaks in the spray manifold. It has been possible to show that if $0.15 \%$ of the drops were $2000 \mu$ in diameter, with the remainder following a log-normal distribution having a geometric mean of $100 \mu$ and a geometric standard deviation of 1.5; the half-life would be of the magnitude observed.

The ORNL program appears to predict too short a half-life for very fine drops and too long a half-life for coarse drops, but for drop diameters in the range of 600 to $1000 \mu$, the prediction is close to being correct. In view of the sensitivity. of the calculation to drop size and size distribution, the assumptions about distribution as the probable cause of the discrepancies should be examined. 
It is premature to draw firm conclusions at this time. The observed half-lives are short enough to affirm that a significant dose-reduction factor can be obtained by using sprays to reduce the airborne elemental iodine concentration. It is believed that these results can be applied directly in larger vessels if the same solutions, nozzles, and flows (per nozzle and per unit area) are used. The computation model developed gives results of the same order as found experimentally. Further improvements are being made to the model to produce a satisfactory routine for predicting gas film coefficients.

\subsection{Radiation Stability of Spray Solutions}

A program was initiated for measuring the stability of the various proposed spray solutions under a variety of conditions: ${ }^{24}$. (1) 1 wt \% $\mathrm{Na}_{2} \mathrm{~S}_{2} \mathrm{O}_{3}, 3000 \mathrm{ppm} \mathrm{B}$, and $0.153 \underline{\mathrm{M} \mathrm{NaOH}}$ in $\mathrm{H}_{2} \mathrm{O}$; (2) $3000 \mathrm{ppm} \mathrm{B}$ and $0.153 \underline{\mathrm{M}}$ $\mathrm{NaOH}$ in $\mathrm{H}_{2} \mathrm{O}$; (3) distilled $\mathrm{H}_{2} \mathrm{O} ;(4), 3000$ ppm $\mathrm{B}$ in $\mathrm{H}_{2} \mathrm{O}$; and (5) 1 wt \% $\mathrm{Na}_{2} \mathrm{~S}_{2} \mathrm{O}_{3}$ and 3000 ppm $\mathrm{B}$ in $\mathrm{H}_{2} \mathrm{O}$.

\subsubsection{Effect of Radiation on $\mathrm{pH}, \mathrm{I}_{2}$ Equivalence, and} Solids Formation.

The initial study illustrated the effect of ${ }^{60} \mathrm{Co}$ gamma radiation on the $\mathrm{pH}$ of all solutions and the iodine reaction capabilities of the $\mathrm{Na}_{2} \mathrm{~S}_{2} \mathrm{O}_{3}$ solutions. The data obtained are presented in Table 7.11.

The $\mathrm{pH}$ of each solution studied decreased as a function of radiation dose. Solution 5 (acidic thiosulfate) showed the greatest effect and thus indicated the largest amount of radiolytic reaction. On comparing solutions 1 and 5 (basic and acidic thiosulfate) it is also noted that the degradation of the thiosulfate, as measured by its ability to react. with iodine, is much more severe in the acidic solution. No deposition of solids was noted in the basic thiosulfate, while fairly substantial amounts were formed in the acid solution on irradiation. This indicates that the reactive routes of the two solutions with the radiolytic reactive entities are entirely different. 
Table 7.11. Effect of ${ }^{60} \mathrm{Co}$ Gamma Radiation on $\mathrm{pH}, \mathrm{I}_{2}$ Equivalence, and Solids Formation

\begin{tabular}{|c|c|c|c|c|c|c|}
\hline $\begin{array}{l}\text { Solution } \\
\text { No. }\end{array}$ & $\begin{array}{l}\text { Dose } \\
(r)\end{array}$ & $\mathrm{pH}$ & $\begin{array}{l}\mathrm{I}_{2} \text { Equivalents } \\
\text { per Liter }\end{array}$ & $\begin{array}{c}\mathrm{I}_{2} \text { Equivalents } \\
\text { Destroyed } \\
(\%)\end{array}$ & $\begin{array}{c}\mathrm{G}^{\mathrm{b}} \mathrm{I}_{2} \\
\text { Equivalents }\end{array}$ & $\begin{array}{l}\text { Solids } \\
\text { (mg per ml of } \\
\text { solution) }\end{array}$ \\
\hline 1 & $\begin{array}{l}\text { Unirradiated } \\
9 \times 10^{5} \\
1 \times 10^{7} \\
2 \times 10^{7} \\
5 \times 10^{7} \\
1 \times 10^{8}\end{array}$ & $\begin{array}{l}9.2 \\
9.2 \\
9.1 \\
9.0 \\
8.9 \\
8.5\end{array}$ & $\begin{array}{r}-6.0 \times 10^{-5} \\
-1.7 \times 10^{-3} \\
-1.3 \times 10^{-3} \\
9.0 \times 10^{-3} \\
3.0 \times 10^{-2}\end{array}$ & $\begin{array}{l}-0.1 \\
-2.6 \\
-2.1 \\
1.3 .9 \\
43.2\end{array}$ & $\begin{array}{l}0.2 \\
0.3\end{array}$ & $\begin{array}{l}\text { None detected } \\
\text { None detected } \\
\text { None detected } \\
\text { None detected } \\
\text { None detected }\end{array}$ \\
\hline 2 & $\begin{array}{l}\text { Unirradiated } \\
9 \times 10^{5} \\
1 \times 10^{7} \\
2 \times 10^{7} \\
5 \times 10^{7}\end{array}$ & $\begin{array}{l}9.3 \\
9.3 \\
9.3 \\
9.2 \\
9.2\end{array}$ & & & - & \\
\hline 3 & $\begin{array}{l}\text { Unirradiated } \\
5 \times 10^{5} \\
1 \times 10^{7} \\
2 \times 10^{7} \\
5 \times 10^{7}\end{array}$ & $\begin{array}{l}6.2 \\
6.2 \\
6.1 \\
6.0 \\
5.9\end{array}$ & & & & \\
\hline 4 & $\begin{array}{l}\text { Unirradiated } \\
9 \times 10^{5} \\
1 \times 10^{7} \\
2 \times 10^{7} \\
5 \times 10^{7}\end{array}$ & $\begin{array}{l}4.7 \\
4.7 \\
4.7 \\
4.6 \\
4.5\end{array}$ & - & & . & \\
\hline 5 & $\begin{array}{l}\text { Unirradiated } \\
9 \times 10^{5} \\
1 \times 10^{7} \\
2 \times 10^{7} \\
5 \times 10^{7} \\
1 \times 10^{8}\end{array}$ & $\begin{array}{l}4.9 \\
4.4 \\
3.8 \\
3.7 \\
3.6 \\
3.2\end{array}$ & $\begin{array}{r}1.2 \times 10^{-3} \\
8.0 \times 10^{-3} \\
15.7 \times 10^{-3} \\
36.5 \times 10^{-3} \\
62.8 \times 10^{-3}\end{array}$ & $\begin{array}{r}1.8 \\
12.4 \\
24.3 \\
56.2 \\
97.2\end{array}$ & $\begin{array}{l}1.3 \\
0.8 \\
0.8 \\
0.7 \\
0.6\end{array}$ & $\begin{array}{c}\text { None detected } \\
\text { None detected } \\
0.16 \\
0.46 \\
1.65\end{array}$ \\
\hline
\end{tabular}

$a_{A}$ negative value indicates an increase of $\mathrm{I}_{2}$ equivalence upon irradiation.

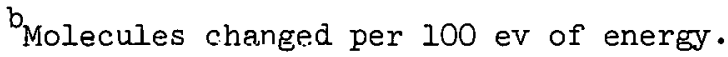

\section{$\% .5 .2$ Radiolytic Iydrogen Production}

The amount of radiolytic hydrogen that might be produced from the spray solutions has been of prime interest. The data of Table 7.12 shows the relative amounts of radiolytic hydrogen produced in each of the five tcet solutions and indicate that the amount is a function of the solution composition. However, later studies indicate that this is only one aspect of the real case. The total amount of oxygen available in the system, as expressed by the gas-to-liquid ratio, is also of great importance. The magnitude of the effect is shown in Table 7.13. (The gas in each case was air.) The data imply that the oxygen in the cover gas enters into 
Table 7.12. Radiolytic Hydrogen Production in Spray Solutions

Total radiation dose, all samples: $1 \times 10^{7} \mathrm{r}$ Gas-to-liquid ratio: $\sim 0.9$

\begin{tabular}{ccc}
$\begin{array}{c}\text { Solution } \\
\text { No. }\end{array}$ & $\begin{array}{c}\mathrm{H}_{2} \text { Evolved } \\
(\mathrm{cc} / \mathrm{ml})\end{array}$ & $\mathrm{G}\left(\mathrm{H}_{2}\right)^{\mathrm{a}}$ \\
\hline 1 & $2.3 \times 10^{-1}$ & 1.0 \\
2 & $1.1 \times 10^{-1}$ & 0.48 \\
3 & $3.2 \times 10^{-2}$ & 0.14 \\
4 & $4.9 \times 10^{-2}$ & 0.21 \\
5 & $1.3 \times 10^{-1}$ & 0.57 \\
\hline \multicolumn{3}{c}{ aolecules changed per $100 \mathrm{ev}$}
\end{tabular}

Table 7.13. Effect of Gas-to-Liquid Ratio on Radiolytic Hydrogen Production in Test Solution I

Total radiation dose, all samples: $4 \times 10^{7} \mathrm{r}$ Test conditions: all sample capsules sealed with gas-to-liquid ratio shown

\begin{tabular}{ccc}
$\begin{array}{c}\text { Gas-to-Liquid } \\
\text { Ratio }\end{array}$ & $\begin{array}{c}\mathrm{H}_{2} \text { Evolved } \\
(\mathrm{cc} / \mathrm{ml})\end{array}$ & $\mathrm{G}\left(\mathrm{H}_{2}\right)^{\mathrm{a}}$ \\
\hline 50 & 0.16 & 0.2 \\
25 & 0.26 & 0.3 \\
8 & 0.41 & 0.4 \\
3 & 0.57 & 0.6 \\
0.8 & 0.92 & 1.0 \\
\hline Molecules changed per 100 ev of \\
energy.
\end{tabular}

reaction with either the radiolytic water products or with the radiolytically produced products of the thiosulfate to cause a change in reaction route and/or rate. Other studies, as yet incomplete, indicate 
that the radiolytic hydrogen production is more severe after the available oxygen is depleted. This being the case, the dose required to deplete the oxygen in each of the test solutions in Table 7.12 would vary, and the results given are more a function of rate and route of oxygen depletion than of solution makeup, with the rate of oxygen depletion depending on oxygen solubility in any given solution, mode of oxygen reaction, etc.

In order to clarify the situation, a study was carried out with the gas-to-liquid ratio being such that the oxygen was not entirely depleted in any case. This study was also used to establish the radiolytic hydrogen versus total dose relationship. The results are given in Table 7.14 . The data indicate that the radiolytic hydrogen production is essentially a linear function of total dose and that the available oxygen does play an important role. The three solutions studied showed essentially the same radiolytic hydrogen versus total dose relationship; whereas, when the $\mathrm{O}_{2}$ was depleted (Table 7.13), they showed entirely different amounts of radiolytic hydrogen production.

The question arose as to whether the radiolytic hydrogen production is a function of dose rate over those ranges of dose rate expected to occur in actual use. The results of a study carried out to clarify this

Table 7.14. Radiolytic Hydrogen Production as a Function of Total Dose

Gas-to-liquid ratio, all samples: 25

\begin{tabular}{cccc}
\hline \multirow{2}{*}{ Dose $(r)$} & \multicolumn{3}{c}{ Radiolytic $\mathrm{H}_{2}$ Produced $(\mathrm{cc} / \mathrm{ml})$} \\
\cline { 2 - 4 } & Solution 1 & Solution 2 & Solution 3 \\
\cline { 3 - 4 }$\times 10^{7}$ & & & \\
1.0 & 0.5 & 0.6 & 0.06 \\
1.87 & 0.11 & 0.15 & 0.12 \\
2.81 & 0.27 & 0.23 & 0.27 \\
4.74 & 0.36 & 0.42 & 0.37 \\
9.46 & 0.69 & 0.69 & 0.73 \\
\hline
\end{tabular}


point are given in Table 7.15. The data of Table 7.15 indicate essentially no effect of dose rate on radiolytic hydrogen production.

The results obtained to date in the study of the various proposed 'spray solutions' indicate that radiolytic hydrogen is produced in quantities sufficient to be of concern in the proposed spray system. Therefore, another study has been initiated to determine the feasibility of other additives to decrease the radiolytic hydrogen production. Such additives may react with either the radiolytic hydrogen or with its precursor, the hydrogen free radical. The nitrate ion is known to lower the radiolytic hydrogen yield by scavenging the hydrogen atom. Therefore, a brief study of the effects of such added nitrate was made. The results are given in Table 7.16. The data show a definite decrease in radiolytic hydrogen production with increasing $\mathrm{NO}_{3}^{-}$concentration. However, while these data indicate that the radiolytic hydrogen production may be reduced by addition of "scavengers," the question of the compatibility of such additives with the usage and purpose of the spray solutions must be studied in detail.

Table 7.15. Radiolytic Hydrogen Production of Solution 1 as a Function of Dose Rate

Total dose, all samples: $1 \times 10^{7} \mathrm{r}$

Gas-to-liquid ratio: 25

\begin{tabular}{ll}
\hline $\begin{array}{c}\text { Dose Rate } \\
(\mathrm{r} / \mathrm{min})\end{array}$ & $\begin{array}{c}\text { Radiolytic } \mathrm{H}_{2} \\
\text { Produced } \\
(\mathrm{cc} / \mathrm{ml})\end{array}$ \\
\hline $1.0 \times 10^{3}$ & 0.05 \\
$4.8 \times 10^{3}$ & 0.05 \\
$7.0 \times 10^{3}$ & 0.06 \\
$1.6 \times 10^{4}$ & 0.06 \\
$1.0 \times 10^{5}$ & 0.06 \\
\hline
\end{tabular}




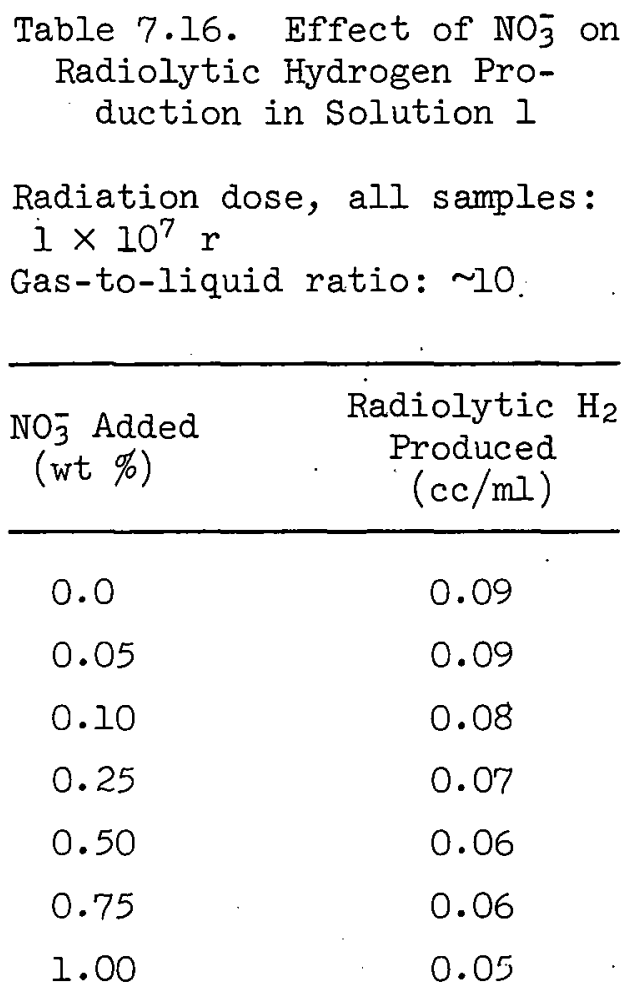

\section{5 .3 Discussion}

The radiolytic reactions that spray solutions undergo are of interest and importance. Accordingly, the radiolytic behavior of the thiosulfate ion under various conditions of acidity and oxygen availability is under study. The following reactions are proposed as those that may occur between the radiolytic water products $\left(\mathrm{H}, \mathrm{OH}\right.$, and $\left.\mathrm{H}_{2} \mathrm{O}_{2}\right)$ and the thiosulfate ion:

$$
\begin{gathered}
2 \mathrm{~S}_{2} \mathrm{O}_{3}^{2-}+2 \mathrm{OH}+2 \mathrm{H}^{+} \rightarrow \mathrm{S}_{4} \mathrm{O}_{6}^{2-}+2 \mathrm{H}_{2} \mathrm{O} \\
2 \mathrm{~S}_{2} \mathrm{O}_{3}^{2-}+\mathrm{H}_{2} \mathrm{O}_{2}+2 \mathrm{H}^{-1} \rightarrow \mathrm{S}_{4} \mathrm{O}_{6}^{2-}+2 \mathrm{H}_{2} \mathrm{O} \\
2 \mathrm{~S}_{2} \mathrm{O}_{3}^{2-}+8 \mathrm{OH} \rightarrow \mathrm{S}_{3} \mathrm{O}^{2-}+\mathrm{SO}_{4}^{2-}+4 \mathrm{H}_{2} \mathrm{O} \\
\mathrm{S}_{2} \mathrm{O}_{3}^{2-}+4 \mathrm{OH} \rightarrow 2 \mathrm{SO}_{3}^{2-}+\mathrm{H}_{2} \mathrm{O}+2 \mathrm{H}^{+} \cdot \\
2 \mathrm{~S}_{2} \mathrm{O}_{3}^{2-}+12 \mathrm{OH}+4 \mathrm{OH}^{-} \rightarrow 4 \mathrm{SO}_{3}^{2-}+8 \mathrm{H}_{2} \mathrm{O}+\mathrm{O}_{2} \\
\mathrm{~S}_{2} \mathrm{O}_{3}^{2-}+8 \mathrm{H} \rightarrow 2 \mathrm{~S}^{2-}+3 \mathrm{H}_{2} \mathrm{O}+2 \mathrm{H}^{+} \\
\mathrm{S}_{2} \mathrm{O}_{3}^{2-}+2 \mathrm{OH} \rightarrow \mathrm{SO}_{4}^{2-}+\mathrm{S}+\mathrm{H}_{2} \mathrm{O} .
\end{gathered}
$$


Each of the sulfur-containing reaction products shown was found to be formed to some degree in the radiolytic decomposition of thiosulfate under differing conditions. Obviously, the problem of clearly defining the exact route of reaction is a complex and difficult one, and it will be carried out only so far as is necessary to the spray program.

The work to this point has dealt with only the radiation stability of the proposed thiosulfate sprays. Further work is being carried out to clearly define the thermal and chemical stability of these sprays. Additional work is contemplated on the radiation, thermal, and chemical stability of other proposed spray additives, such as hydrazine, cyclohexane, etc.

\section{$\underline{\text { References }}$}

1. I. C. Schwendiman et al., The Washout of Methyl Iodide by Hydrazine Sprays, Progress Report (through September 1957), USAEC Report BNWL-530, Pacific Northwest Laboratory, 1957.

2. T. H. Row (Coordinator), Spray and Absorption Technology, pp. 193-207, Nuclear Safety Program Ann. Progr. Rept. Dec. 31, 1967, USAEC Report ORNL-4228, Oak Ridge National Laboratory.

3. Wm. B. Cottrell, Nuclear Safety Research and Development Program Bimonthly Report for March-April 1968, USAEC Report ORIV-TM-223n, pp. 55 85, Oak Ridy'e INational Laboratory, May 30, 1968.

4. C. S. Patterson and W. T. Humphries, Equilibrium Distribution of $\mathrm{I}_{2}$ Between Nitrogen Streams and Aqueous Solutions at $25^{\circ} \mathrm{C}$, pp. 193-202 in Nuclear Safety Program Ann. Progr. Rept. Dec. 31., 1967, USAEC Report ORNL-4228, Oak Ridge National Laboratory.

5. C. S. Patterson and W. T. Humphries, Iodine Capacities of Some Aqueous Solutions, pp. 48-50 in ORNL Nuclear Safety Research and Development Program Bimonthly Report for January-February 1968, USAEC Report ORNL-TM-2164, Oak Ridge National Laboratory, March 1968.

6. C. S. Patterson and W. T. Humphries, Iodine Capacity Coefficients for a Variety of Aqueous Solutions, pp. 59-62 in ORNL Nuclear Safety Research and Development Program Bimonthly Report for March-April 1968, USAEC Report ORNL-TM-2230, Oak Ridge National Laboratory, May 30, 1968.

7. A. E. J. Eggleton, A Theoretical Examination of Iodine-Water Partition Coefficients, British Report AERE-R4887, February 1967. 
8. V. Griffiths, The Removal of Iodine from the Atmosphere by Sprays, British Report AHSB(S)-R45, January 1963.

9. C. S. Patterson and W. T. Humphries, Iodine Capacities of Reactive Solutions, pp. 20-24 in ORNL Nuclear Safety Research and Development Program Bimonthly Report for November-December 1957, USAEC Report ORNL-TM-2095, Oak Ridge National Laboratory, February 1968.

10. A. D. Awtrey and R. E. Connick, Rate Law and Mechanism of the Reaction of Iodine with Tetrathionate Ion, J. Am. Chem. Soc., 73: $4546-4549$ (1951).

11. A. Siedell, Solubilities of Inorganic and Metal Organic Compounds, Vol. 1, Van Nostrand, INew York, 1958.

12. B. A. Soldano and W. T. Ward, Behavior of Fission Products in GasLiquid Systems, pp. 33-37 in ORNL Nuclear Safety Research and Development Program Bimonthly Report for September-October 1967, USAEC Report ORNL-TM-2057, Oak Ridge National Laboratory, November 1967.

13. K. W. Doak and A. H. Corwin, Kinetics of Pyrrole Substitutions. The Iodine Reaction, J. Am. Chem. Soc., 71: 159 (1949).

14. N. D. Cheronis and T. S. Ma, Organic Functional Group Analysis, Wiley, New York," 1964.

15. B. A. Soldano and W. T. Wärd, Uptake of $\mathrm{CH}_{3} I$ by a Suspended Drop of Water Solution, pp. 202-215, Nuclear Safety Program Ann. Progr. Rept. Dec. 31, 1967, USAEC Report ORNL-4228, Oak Ridge National Laboratory, April 1968.

16. F. H. Garner and J. J. Lane, Mass Transfer to Drops of Liquid Suspended in a Gas Stream, Part II. Experimental Work and Results, Trans. Inst. Chem. Engrs. (London), 37: 162-172 (1959).

17. B. A. Soldano and W. T. Ward, Uptake of $\mathrm{I}_{2}$ and $\mathrm{CH}_{3} \mathrm{I}$ by Water Solutions and Drops, pp. 63-73 in ORNL Nuclear Safety Research and Development Program Bimonthly Report for March-April 1968, USAEC Report ORNL-TM-2230, Oak Ridge National Laboratory, May 30, 1968.

18. I. F. Parsly and J. K. Franzreb, Spray Tests in the Nuclear Safety Pilot Plant, pp. 22l-23l in Nuclear Safety Program Ann. Progr. Rept. Dec. 31, 1967, USAEC Report ORNL-4228, Oak Ridge National Laboratory.

19. L. F. Parsly and J. K. Franzreb, Spray Experiments in the Nuclear Safety Pilot Plant, pp. 74-76 in ORNL. Nuclear Safety Research and Development Program Bimonthly Report for March-April 1968, USAEC Report ORIL-TM-2230, Oak Ridge National Laboratory. 
20. B. A. Soldano and W. T. Ward, Mass Transfer of $\mathrm{CH}_{3} I$ into Aqueous Drops, pp. 24-27 in ORNL Nuclear Safety Research and Development Program Bimonthly Report for November-December 1967, USAEC Report ORNL-TM-2095, Oak Ridge National Laboratory.

21. W. D. Fletcher, Westinghouse Electric Corporation, personal communication.

22. R. K. Hilliard, Pacific Northwest Laboratories, personal communication.

23. T. Maekawa èt al., J. Atomic Energy Soc. Japan, 7: 563 (1965).

24. H. E. Zittel, Radiation Stability of Spray Solutions, pp. 231-237 in Nuclear Safety Program Ann. Progr. Rept. Dec. 31, 1967, USAEC Report ORNL-4228, Oak Ridge National Laboratory. 


\section{AIR CLEAINP POTENTIAL OF PRESSURE-SUPPRESSION POOLS}

Pressure-suppression containment in specific reactor systems was described in section 3.1.4. A comprehensive literature review on pool suppression literature is appended to this report (see App. A). A more extensive report that also includes all spray literature will be prepared as part of the ORNL Spray Technology Program. Much of the more relevant literature in these bibliographies is referenced in the various chapters of this report. This chapter is concerned with program,planning and recent experiments related to the scavenging of fission products by suppression pools.

The pressure-suppression type of containment is an integral emergency safety feature in General Electric Company boiling-water reactors. This containment, system consists of the following: a primary fission-product barrier, the pressure-suppression system; a secondary barrier, the reactor building; and a standby gaș treatment system to insure only inleakage to the reactor building in case of accident conditions. Although some statements were made in connection with the Humboldt Bay Nuclear Power Units regarding the iodine-scrubbing potential of the suppression pool, there was little supporting experimental evidence of the decontamination factors claimed. However, in view of the increased incentives for fission-product removal the cleanup potential of suppression pools is now being reassessed by both the AEC and the General Electric Company.

The pressure-suppression system consists of the drywell in which the reactor vessel is located, a pressure-suppression chamber that stores a large volume of water, a connecting vent system between the drywell and the water pool, isolation valves, containment cooling systems, and other scrvice equipment. In the event of a process system piping failure within the drywell, reactor water and steam would be released into the drywell. The resulting increased drywell pressure would then force a mixture of drywell gases, steam, and water through the vents into the pool of water stored in the suppression chamber. Some of the fission products released by fuel-rod perforations would also be forced through the vents into the suppression chamber. The steam would condense in the suppression pool, 
and a rapid pressure reduction in the drywell would result. Gases transferred to the suppression chamber would pressurize the chamber and subsequently be vented to the drywell to equalize the pressures between the two vessels. The cooling systems provided would remove heat from the reactor core, the drywell, and the water in the suppression chamber and thus provide continuous cooling of the primary containment system under accident conditions. Appropriate isolation valves would be actuated during this period to insure containment of the radioactive materials that might be released from the reactor during the course of the accident within the primary containment system. One of the more unfamiliar events that occurs during a loss-of-coolant accident is the transport of fission products, and the pressure-suppression chamber pool is an important barrier in reducing the transport of these fission products through the containment systems.

Since most of the work on the scavenging of fission products has only recently been initiated, there is little of significance to relate. Hence the following summaries of current research and development consist principally of brief statements of the objectives of the several relevant activities.

\subsection{Scavenging of Fission Products by Suppression Pools}

Work was begun at ORNL in September 1967 on a modest exploratory program established for the purpose of gaining an understanding of the quantitative aspects of the basic mechanisms that control energy dissipation in pressure-suppression systems. The initial proposal contemplated investigation of the phenomena resulting from the injection of steam and steam-gas mixtures into water. The primary purpose of the present work is to obtain sufficient information to permit confident extrapolation of results obtained in small experimental equipment and to provide adequate design information for engineering application. In particular, it is hoped that appropriate scaling laws can be developed to permit prediction of the behavior of full-size systems from studies of fission-product transport in small models. 
It has been shown that the generation of gas bubbles associated. with the injection of steam into nondegassed water interferes with the determination of the true nature of the steam jet-water interaction. However, such profuse bubble production implies that this phenomenon may be highly significant in transport of fission products in real systems. Observations indicate that little of the gas from the bubbles redissolves in the water. It is therefore probable that these bubbles could enclose fission products and transport them to the atmosphere above the water. It is well known that bubbling gas through a li.quid provides a rather efficient scrubbing action. Therefore, fission-product transport to the surface of pressure-suppression pools may be materially increased by bubble formation upon injection of steam into the nondegassed water used in these systems. This effect will be in addition to those factors previously considered important.

It is thought that the production of bubbles upon the injection of steam into nondegassed water may be a significant factor in the transport of fission products in pressure-suppression systems and that the magnitude of this effect must be determined, in addition to those factors previously considered important. It is also clear from observations to date that pure steam is completely condensed within a few pipe diameters of pipe discharge. This, of course, varies with steam conditions and velocity, as well as water conditions. Quantitative evaluation of the steam jet size and configuration as a function of the influential variables is now in progress. Fhture work will, of course, utilize steam-gas mixtures and water having various concentrations of dissolved gas.

\subsection{Model Tests of Scavenging by Pressure-Suppression Fools}

It id proposed that, the scrubbing mechanism as understood analyti-. cally from the preceding study be incorporated into an analytical model to be evaluated against a scale model of a suppression pool al the General Electric Company. * It is the purpose of the GE program to experimentally

*Work performed under subcontract. 
demonstrate a model of the fission-product accident behavior directly related to the pressure-suppression pools. The prospective advantages of this study are the increased confidence offered in future reactor designs, as well as reduced restrictions on other portions of the fission-product barrier system, such, as the gas-treatment system.

The basis for the scale-model design is a standard General Electric boiling-water reactor (BWR) with an approximately 2400-Mw (th) rating. The volumes and areas for both the prototype and the proposed 1/10,000 scale model are given below:

\begin{tabular}{|c|c|c|}
\hline & Prototype & Model \\
\hline Pressure vessel volume, $\mathrm{ft}^{3}$ & 15,800 & 1.58 \\
\hline Drywell volume, $\mathrm{ft}^{3}$ & 149,700 & 15.0 \\
\hline Suppression chamber volume, $\mathrm{ft}^{3}$ & 216,500 & 21.6 \\
\hline Maximum break size, $\mathrm{ft}^{2}$ & 5.5 & $5.5 \times 10^{-4}$ \\
\hline Downcomer area, $f t^{2}$ & 289 & $2.89 \times 10^{-}$ \\
\hline
\end{tabular}

The blowdown time for a vessel of volume $\mathrm{V}$ through a break of area $\mathrm{A}$ is proportional, to $\mathrm{V} / \mathrm{A}$, and therefore the above $1 / 10,000$-scale model preserves the prototype blowdown time. Since the medium-size standard BWR has 96 downcomers, the model could also be considered a small-scale segment of the prototype, and in this way it could be thought of as a 1/96 segmont of a DWT wLlh volumes and flow areas scaled down by an additional factor of approximately 100.

Analysis-of-variance and multiple-regression techniques will be utilized to examine the effects of the following eight parameters:

1. fission-product concentration,

2. pool temperature,

3. downcomer radial location,

4. air-to-steam ratio,

5. depth of downcomer submersion,

6. containment spray cooling,

7. suppression-pool chemical additives,

8. suppression-pool scaleup factor from $1 / 10,000$ to $1 / 1000$.

The work was just getting under way in the spring of 1968. 


\subsection{Pressure-Suppression Tests in the CSE}

Program objectives, philosophy, and test plans of the Containment Systems Experiment were outlined by Rogers. I The CSF program is designed to evaluate the effectiveness of natural processes and engineered safety features in limiting fission-product release following reactor accidents on a reasonable scale and to investigate engineering aspects of contained coolant-loss accidents in pressurized- or boiling-water reactors fueled with $\mathrm{UO}_{2}$. Test results from the CSE program will permit improvement in the design of engineered safety features. Included in the CSE program are tests of the pressure-suppression containment system. These tests will attempt to verify the ORNL and GE results in large-scale equipment.

\section{Reference}

1. G. J. Rogers, Program for Containment Systems Experiment, USAEC Report HW-83607, Hanford Atomic Products Operation, September 1964. 


\section{SUMMARY AND CONCLUSIONS}

The capabilities and limitations of existing and proposed types of air-cleaning systems in mininizing the release of radioactive fission products to the environment after postulated major accidents in lightwater power reactors are discussed in this report, current research and development programs are summarized, and areas in which additional work is needed are identified. If an accident in the containment shell could result in leakage of fission products into a secondary container, highefficiency filters and charcoal adsorbers would be required in the secondary container to minimize release to the environment. Such air-cleaning systems can significantly reduce the environmental hazard. A combination of filter-adsorber systems and/or spray systems in the containment shell backed up by high-efficiency filter-adsorber systems in the secondary container appears to be a very effective arrangement; variations can be justified under specified conditions.

Once-through filter-adsorber systems that clean and exhaust the air from secondary containment buildings or volumes are recommended as engineered safety features, provided their effective and reliable postaccident performance is assured by proper design, construction, testing, inspection, and maintenance; these systems are widely used in boiling-water reactors with pressure-suppression containment. A once-through system directly attached to the outside of the containment shell of a pressurizedwater reactor should also be adequate if protected from the postaccident containment environment. Because of the high cost of insuring the adequacy of recirculating filter-adsorber systems as, engineered safety features, they are more suitable for containment atmosphere cleanup after minor accidents; these systems are combined with containment cooling systems in many pressurized-water reactors.

High-efficiency particulate (HEPA) filters and charcoal adsorbers are used, often with additional components, such as high-efficiency moisture deentrainment devices (Demisters), coolers, and roughing filters, both in recirculating systems in the containment shell and in once-through systems in secondary containment ventilation. Much of the research and 
development on air-cleaning systems for reactors has been and is directed toward the minimization of failure and the effects of accident environment on the filter. The efficiency of HEPA filters for the removal of aerosols and the efficiency of any one of several impregnated charcoals for the removal of ${ }^{131} \mathrm{I}$ and its gaseous compounds are excellent under controlled conditions, but much lower efficiencies are normally assumed because of allowances for improper installation, deterioration, damage, accident conditions, etc.

Because of their lack of chemical reactivity and their gaseous forms, the noble gases xenon and krypton cannot currently be removed (in a practical way) from the containment shell atmosphere of a commercial reactor during the high-pressure high-temperature stage of a loss-of-coolant accident. Their complete removal from the secondary containment atmosphere is also impractical at present because of their low concentrations and the large air flow. Although noble gases are not presently considered a major hazard when dispersed into the atmosphere, particular attention must be directed to the possible exposure of operating personnel on the reactor site if a major accident occurs. In addition, the disposal of ${ }^{85} \mathrm{Kr}$ (10.3-year half-life), although not now a problem, will require the development of special handling procedures. The only currently practical method of minimizing the discharge of noble gases to the environment during the early stages of an accident is to retain them in a low-leakage containment.system. However, the effect of their release can be minimized by discharge through a high stack. The methods described herein would be applicable only to the cleanup of the containment atmosphere over a several day period following an accident.

Spray cooling systems, adapted for iodine removal by a chemical additive, are being investigated as an alternative to recirculating filteradsorber systems for postaccident air cleanup within containment systems, and the potential of pressure-suppression pools for postaccident air cleanup has been under investigation for some time. Both these systems should be very reliable, but both are generally in the research and development stage, and their effectiveness has not yet been fully evaluated.

Spray systems are required in most reactor plants for cooling the containment. sheil. atmosphere, so incorporation of the additional function 
of iodine removal by the addition of a chemical to the spray water does not represent a major investment. On the other hand, spray systems designed expressly for fission-product control would not be subject to the possible compromises in efficiency that may arise in dual-purpose spray systems in which the water is also used for core cooling. Some proposed containment cooling systems will use cooling methods other than sprays (e.g., ice condensers or fan coolers). In the design of sprays for fission-product removal in such systems, consideration of any spray cooling function would probably be secondary and might even be unnecessary.

The spray and pool-suppression technology program now includes work on literature reviews, a survey of additives for possible use as sprays, corrosion tests, single-drop wind-tunnel studies, scale-model engineering tests, a study on removal of fission products in a pressure-suppression type of containment, and radiation stability of solutions. Close liaison is maintained with the nuclear industry so that the program will cover the practical engineering aspects of the application of spray technology to nuclear facilities.

The rate at which ${ }^{13}{ }^{1}$ I can be removed by liquid sprays depends on the physical form of the fission product and whether the spray combines chemically with the form in which fission products are released. The relatively low removal efficiency of caustic scrubbers for what was presumed to be elemental iodine was an early evidence of the presence of relatively nonreactive compounds that were later identified as aklyl iodides (primarily methyl iodide). In water reactors a considerable portion of the iodine may be released in a molecular form if the fuel melts. Basic studies on the retention of iodine in water were completed, and the results indicate that steam-air bubbles materially reduce the efficiency for iodine removal in the water. The effect of surfactant additives on iodine removal is second order, as determined by the wind-tunnel work. Four methyl iodide experiments and an experiment with iodine vapor have been performed in the Nuclear Safety Pilot Plant at ORNL. The most interesting of these experiments involved $\mathrm{CH}_{3} \mathrm{I}$ removal by a spray with a surfactant in one of the suggested industrial spray solutions. The 
resulting removal half-life and overall decontamination factor appear to suggest that significant $\mathrm{CH}_{3} \mathrm{I}$ removal by sprays can be accomplished.

Radiolysis studies on hydrazine have been completed. The results indicate that the stability is poor and that the radiolytic hydrogen generation rate is greater than that of previously tested solutions. Work on hydrogen production. by solutions of interest is continuing. Thermal stability studies of a thiosulfate system have been completed. Radiation stability of surfactants is being investigated, and some have been shown to have good radiation-damage resistance.

Although spray systems may be expected to be inheréntly more reliable under accident conditions than filter-adsorber systems, their performance as iodine $\left(\mathrm{CH}_{3} \mathrm{I}\right.$ as well as $\left.\mathrm{I}_{2}\right)$ scrubbers is not as well understood as that for filter-adsorber systems. A substantial research and development program is now under way to assess the performance of sprays as engineered safety features. This program is rapidly bringing the level of understanding of sprays up to that of filters for iodine removal under accident conditions. This is not intended to imply that everything that needs to be known about filters has been determined, since that is not the case, and continued filter research and development is anticipated. However, filter-adsorber systems are better understood and have been accepted by the AEC licensing authorities. as engineered safety features for some time, whereas sprays are just now being evaluated for iodine removal.

It may well be that both filter systems and spray systems will be used in conjunction on the same nuclear facility at least in the primary containment enclosure, with the spray system being used during the early stages of the accident transient when the humidity is high and other transient conditions most severe and the filter system being used when the accident transients have largely subsided and the humidity is much less than 100\%. In any event, it appears likely that filter systems will continue to be the preferable choice in secondary containment enclosures, particularly where a negative-pressure atmosphere is maintained. 


\section{RECOMMENDATIONS}

\subsection{HEPA Filters}

The performance of HEPA filters in the removal of test aerosols (e.g., DOP) must be correlated with their performance in the removal of simulated accident-produced aerosols in simulated accident environments if the standard test aerosols are to be considered adequate for the evalua-. tion of air-cleaning systems as engineered safety features.

\subsection{Activated Charcoal and Chemical Adsororbers}

Tests of commercial impregnated charcoals for methyl iodide removal efficiency and tests of loss of impregnant and re-release of adsorbed fission products by impregnated charcoals at elevated temperatures are needed. Also efforts should be made to find or develop a noncombustible agent that will effectively trap methyl iodide in a humid atmosphere. Rates of degradation of charcoal under various service conditions should be established, and replacement schedules based on these analyses should be adhered to conscientiously.

Air-cleaning systems should be designed to reduce the relative humidity of containment air below $100 \%$ before the air reaches charcoal beds to prevent waterlogging of the charcoal and consequent reduction of efficiency for the removal of both methyl iodide and elemental iodine.

\subsection{Once-Through Filter-Adsorber Systems}

All containment systems should have once-through high-efficiency air-cleaning systems to provide controlled release of cleaned containment air to the environment. Even if methods of minimizing pressure and temperature rise, such as the ice condenser, are shown to be sufficient for siting, once-through air-cleaning systems will be needed in the event of a major accident. 


\subsection{Recirculating Filter-Adsorber Systems}

Testing, inspection, and maintenance of recirculating systems within the containment shell present special problems. Visual inspection, direct maintenance, and perhaps certain tests can be accomplished only when the reactor is shut down, and remote testing and inspection may necessitate additional or larger penetrations. Also, because moisture separators, HEPA filters, charcoal adsorbers, and other components may become ex- . tremely radioactive in operation after a reactor accident, means for removing and handling them remotely must be considered.

\subsection{Standby Filter-Adsorber Systems}

Whether air-cleaning systems are operated continuously or held in standby, regular inspection and testing are essential. Filter elements and adsorbers can and do deteriorate, even when not exposed to flowing air.

\subsubsection{Moisture Removal}

Designs of filter-adsorber systems for use as engineered safety features should include adequate moisture-removal devices and prefilters upstream of high-efficiency air-cleaning components. Additional research is needed to develop means for reducing the moisture content of air to a minimum well before the air reaches high-efficiency air-cleaning components. Moisture has a deleterious effect on the ability of high-efficiency filters to withstand pressure differentials, and it reduces the agglomeration of fine aerosols into filterable particles and the ability of activated charcoal to sorb methyl iodide.

\subsection{Chemical Sprays and. Spray Systems}

Research and development on spray solutions, nozzles, and systems should be oriented not only toward dual-purpose systems for both containment cooling and fission-product removal but also toward spray systems designed. specifically for fission-product removal. Chemical sprays should 
not be added to existing systems without careful adaptations to minimize permanent contamination of surfaces by corrosion, deep penetration of fission products into porous materials, washing of radioactive particles into crevïces and into drains not designed to remove high-level radioactive waste, and damage to electrical equipment.

The effects of high radiation fields on promising spray solutions should be determined, with particular reference to radiolytic hydrogen production, formation of precipitates, and effect on ability to react with fission products. The possible accelerative effect of high radiation intensities on the reaction of chemical sprays with methyl iodide should be investigated further.

\subsection{Pressure-Suppression Pools}

The potential of pressure-suppression pools for removal of fission products should be developed further. Notable lines of research in this area are chemical additives to the pool water, transport of fission products to the pool, and control of the amount of time during which unreacted gaseous fission products are retained in the pool (residence time) in order to react with the pool solution and become permanently held.

\subsection{Treatment of Noble Gases}

Practical methods for the retention, storage, and/or disposal of krypton and xenon in large quantities under postaccident conditions should be developed. Research and development on methods of noble gas removal should be continued. Possible methods are room-temperature and lowtemperature adsorption on charcoal, cryogenic enrichment, separation by permselective membranes, solution in liquids, and underground disposal.

\subsection{Reliability of Air-Cleaning Systems}

Ali components of air-cleaning systems for use as engineered safety features must be designed, constructed, and maintained for reliable performance under accident conditions. Housings, gaskets, mounting frames, 
ducts, and dampers, for example, must be as reliable as filter units, charcoal, water deentrainers, motors, and fans.

Standards should be established for the design, construction, installation, and testing of air-cleaning systems for use as engineered safety features in water-cooled power reactors. These systems should be designed with builtin capabilities for convenient in-place testing to the maximum practicable extent. Thorough maintenance and testing of aircleaning systems and components should be emphasized and should be required through administrative control. Proper design alone is not adequate to insure reliable function under accident conditions.

\subsection{Simulation, Characterization, and Transport} of Airborne Fission Products

Research in the production of simulated accident-produced fissionproduct aerosols and gases should be extended and refined to simulate fission products from meltdown and loss of coolant as accurately as possible.

\subsection{Analytical Models and Applications of Theory}

As more data become available from laboratory experiments and particularly from pilot-plant experiments, such as those in the NSPP, and large-scale experiments, such as those in the CSE and LOFT, analytical morels of fission-product release and transport during design-basis accidents should be further developed and refined, to be able to predict fission-product behavior more realistically, if possible, than can be presentily done. 


\section{PAGES 112 to 114 WERE INTENTIONALLY LEFT BLANK}


Appendix A

BIBLIOGRAPHY OF SUBJECTS RELATED TO FISSION-PRODUCT TRAPPING IN PRESSURE-SUPPRESSION POOLS

\section{Pressure Suppression}

The pressure-suppression literature cites primarily work on steam condensation and pressure-temperature behavior following blowdown. Parametric fission-product trapping studies at the British Atomic Energy Research Establishment, as well as work concerned with metal-water reactions and condensing steam environments, are included.

Ashworth, C. P., Fission Product Transport in Pressure Suppression Containment, Proceedings of International Symposium on Fission Product

1 Release and Transport. Under Accident Conditions, Held at Oak Ridge, Tennessee, April 5-7, 1965, USAEC Report CONF-650407, Vol. 2, pp. 753-775.

Ashworth, C. P.; Barton, D. B.; Robbins, C. H.; Pressure Suppression, $\checkmark$ Nuclear Energy, pp. 313-321, August 1962.

Diffey, H. R.; Rumary, C. H.; Smith, M. J. S.; Stinchcombe, R. A.; Iodine

3 Clean-Up in a Steam Suppression System, British Report AERE-R-4882, May 1965.

Q Fiock, W. L., Pressure Suppression Containment, Atomics, 15(2): 21-24 (April 1962).

- Genco, J. M., Metal-Water Reactions, Reactor Materials, 10(1): 32-33

$\checkmark$ (Spring 1967).

General Electric Company and Pacific Gas and Electric Company, Pressure $\checkmark$ Suppression Development Program, Appendix IV, Final Hazards Summary Report, Humbolat Bay Power Plant Unit No. 3, September 1961.

General Electric Company and Pacific Gas and Electric Company, Pressure 7 Suppression Test Program, Appendix I, Preliminary Hazards Summary Report, Bodega Bay Atomic Part Unit No. 1, December 1962.

Mr.Goff, M. J.; Rodgers, S. J.; Simulation of Container Venting Under Sea f Water, MSA Kesearch Corporation Techrical Report 59, Dec. 31, $195 \%$.

McCormack, J. D.; Hilliard, R. K.; Natural Removal of Fission Products Released From $\mathrm{UO}_{2}$ Fuel in Condensing Steam Environments, Proceedings of

Y International Symposium on Fission Product Release and Transport Under Accident Conditions, Held at Oak Ridge, Tennessee, April 5-7, 1965, USAEC RejpuIl CONP-6504O7, Vol. 1, pp. 178-211. 
Smith, M. J. S.; Rumary, C. H., Diffey, H. R.; Radioactive Iodine and

O Aerosol Decontamination and Condensation Efficiency Studies in a Steam Suppression System, British Report AERE-PR/CE-10 excerpt (articles from a progress report), pp. 11-17, April 1966.

Stinchcombe, R. A., and Goldsmith, P., Removal of Iodine from the Atmo-

I sphere by Condensing Steam, J. Nucl. Energy, Parts A/B, 20(4): 261-275 (April 1966).

Whelchel, C. C.; Robbins, C. H.; Pressure Suppression Containment for Nuclear Power Plants, Nucl. Energy, pp. 263-271, June 1960.

\section{Bubble Behavior}

An extensive search of the literature on rising bubble behavior was made to aid in the theoretical analysis of fission-product gases bubbling through pressure-suppression pools. Several references are related to the physical properties of water and the effects of certain additives on those properties that might have an effect on bubble behavior.

Y Akiyama, M., Spherical Bubble Collapse in Uniformly Subcooled Liquids, Bull. Japan Soc. Mech. Eng., 8(32): 683-694 (November 1965).

Ashworth, C. P., Fission Product Transport in Pressure Suppression Con$\psi$ tainment, Proceedings of International Symposium of Fission Product Release and Transport Under Accident Conditions, Held at Oak Ridge, Tennessee, April 5-7, 1965, USAEC Report CONF-650407, Vol. 2, pp. 753-775.

I Bankoff, S. G., A Note on Latent Heat Transport in Nucleate Boiling, A.I.Ch.E. Journal, 8(1): 63-65 (March 1962).

Bankoff, S. G., Bubble Dynamics in Boiling, Proceedings of Conference $\checkmark$ on Boiling and Two-Phase Flow for Heat Transfer Engineers, Berkeley/Los

- Angeles, California, May 27-28, 1965, AED-Conf-65-124-15, pp. 21-36, March 1966.

^ Bankoff, S. G., Diffusion-Controlled Bubble Growth, Advan. Chem. Eng., 6: $1-60(1966)$.

\$ Bankoff, S. G., Heat Conduction or Diffusion with Changes of Phase, Advan. Chem. Eng., 5: 75-150 (1964).

Bankuff, S. G., Asymptotic Growth of a Bubble in a Liquid with Uniform Initial Superheat, Appl. Sci.Res., Sect. A, 12: 267-281 (1963-64). 
Bellman, R., and Pennington, R. H.; Effects of Surface Tension and Vis$\uparrow$ cosity on Taylor Instability, Quart. Appl. Math., 12(2): 151-162 (1954).

Bird, R. Byron, The Equations of Change and the Macroscopic Mass, MomenW. tum, and Energy Balances, Chem. Eng. Sci., 6: 123-131 (1957).

Bird, R. Byron; Stewart, Warren E.; and Lightfoot, E. N.; Transport Pheiv nomena, Wiley, 1960.

7 Birkhoff, G.; Margulies, R. S.; and Horning, W. A.; Spherical Bubble $\vartheta$ Growth, Phys. Fluids, I(3): 201-204 (May-June 1958).

$\alpha$ Cambel, A. B., ard Jennings, B. II., Gas Dynamics, McGraw-Hill, 1958. WCheers, F., Elements of Compressible Flow, Wiley, 1963.

Chu, P. T., and Hammitt, F. G., Natural Convection Inside a Circular WCavity, paper presented at Winter Meeting of the ASME, November, 1964, Conf. 763-29.

Claussen, W. F., Surface Tension and.Surface Structure of Water, Science, ग.1.56: 1226-1227 (June 2, 1967).

Cole, R., Motion of Vapor Bubbles in Saturated Liquids, A.I.Ch.E. Journal, VI3 (2): 403-404 (March 1967).

Daily, J. W., and Harleman, D. R. F., Fluid Dynamics, Addison-Wesley, VI966.

Datta, R. L.; Napier, D. H.; Newitt, D. M.; The Properties and Behavior of Gas Bubbles Formed at a Circular Orifice, Trans. Inst. Chem. Eng., 28: 14-26 (February 1950).

1 Davidson, L., and Amick, E. H., Jr., Formation of Gas Bubbles at Horizontal Orifices, A.I.Ch.E. Journal, 2(3): 337-342 (September 1956).

WDavies, R. (Ed.), Cavitation in Real Liquids, Elsevier Publishing Company, 31964.

Davies, R. M., and Taylor, G., The Mechanics of Large Bubbles Rising

$\eta$ Through Extended Liquids and Through Liquids in Tubes, Proc. Roy. Soc. London, Series A, 200: 375-390 (February 1950).

(f) Dergarabedian, Paul, The Rate of Growth of Vapor Bubbles in Superheated Water, J. Appl. Mech., pp. 537-545, December 1953.

I ERA 1967 Steam Tables - Thermodynamic Properties of Water and Steam, 1. PViscosity of Water and Steam, Thermal Conductivity of Water and Steam, St. Martin's Press, New York, $1.96 \%$ 
Fauske, Hans K., Contribution to the Theory of Two-Phase, One-Component 3 Critical Flow, USAEC Report ANL-6633, Argonne National Laboratory, October 1962.

Fair, J. R., Designing Gas-Sparged Reactors, Chem. Eng., pp. 67-74, A) July 3, 1967.

( Florschuetz, L. W., and Chao, B. T., On the Mechanics of Vapor Bubble i Collapse, J. Heat Transfer, Trans. ASME, pp. 209-220, May 1965.

Florschuetz, L. W., and Chao, B. T., On the Mechanics of Vapor Bubble A Collapse - A Theoretical and Experimental Investigation, USAEC Report M TID-19860, October 1963.

Forster, H. K., and Zuber, N., Growth of a Vapor Bubble in Superheated Niquid, J.. Appl. Phys., 25(4): 474-478 (April 1954).

Gadd, G. E., Reduction of Turbulent Friction in Liquids by Dissolved NAdditives, Nature, 212: $874-877$ (Nov. 26, 1966).

Gilmore, F. R., The Growth or Collapse of a Spherical. Bubble in a Viscous N Compressible. Liquid, pp. 53-64 in Proceedings. of Heat Transfer and Fluid.

W Mechanics Institute; Los Angeles, California, June 1952.

Haberman, W. L., and Morton, R. K., An Experimental Investigation of the N Drag and Shape of Air Bubbles Rising in Various Liquids, Report DTMB-802, September 1953.

LHansen, Arthur G., Similarity. Analysis of Boundary Value Problems in

NEngineering, Prentice. Hall, New York, 1964.

W Harmathy, 'l'ibor Z., Velocity of Large Drops and Bubbles in Media of Infinite or Restricted. Extent,. A.I.Ch.E. Journal, 6(2): 281-288 (1960).

U Hayes, W. B., III; Hardy, B. W.; and Holland, C. D.; Formation of Gas Bubbles at Submerged Orifices, A.I.Ch.E. Journal, 5(3): $319-324$ (September 1959).

๙ेHickling, Robert, and Plesset, M. S., Collapse and Rebound of a Spherical Bubble in Water, Phys. Fluịds, 7(1): 7-14 (January 1964).

PoHiggins, H. M., Dynamics of Large Vapor Bubbles, in Water - Description of Film, pp. 236-249 in Cavitation in Fluid Machinery, ASME, 1965.

2 Hsieh, D., Some Analytical Aspects of Bubble Dynamics, J. Basic Eng., Trans. ASME, pp. 991-1005, December 1965.

DHsieh, Din-Yu, and Plesset, M. S., Theory of Rectified Diffusion of Mass ninto Gas Bubbles, J. Accoust. Soc. Am., 33(2): 206-215 (February 1961). 
Hughes, R. R.; Handlos, A. E.; Evans, H. D.; and Maycock, R. L.; The 5 Formation of Bubbles at Simple Orifices, Chem. Eng. Progr., 51(12): 557-563 (December 1955).

NHunter, C., On the Collapse of an Empty Cavity in Water, Fluid Mech.,
5 8: 241-263. Isbin, H. S., et al., Critical Flow Phenomena in Two-Phase Mixtures and 3 their Relationships to Nuclear Safety, Proceedings of Third International Conference on Peaceful Uses of Atomic Energy, Geneva, 1964, Vol. 8, pp. 286-294, United Nations, New York, 1964.

Isbin, H. S., and Gavalos, G. R., Two Phase Flow through an Aperture, Mroceedings of the 1962 Heat Transfer and Fluid Mechanics Institute Held in Washington, D.C., June 13-15, 1962, Stanford University Press, 1962.

GIsbin, H. S.; May, J. E.; and DaCruz, A. J. R.; Two-Phase, Steam-Water C Critical Flow, A.I.Ch.E. Journal, 3(2): 361-365 (September 1957).

Alsbin, H. S.; Nishiwaki, Ichiro; and Klein, L. A.; Condensation of Steam $\checkmark$ in Steam-Air Bubbles Immersed in Water, USAEC Report TID-6520.

M Ivany, R. D., and Hammit, F. G., Cavitation Bubble Collapse in Viscous,

5 Compressible Liquids - Numerical Analysis, Trans. ASME, J. Basic Eng., pp. 977-985, December 1965.

Ivany, R. D.; Hammit, F. G.; Mitchell, T. M.; Cavitation Bubble Collapse

O Observations in a Venturi, Trans. ASME, J. Basic Eng., pp. 649-657, September 1966.

Jakobsen, J: K., On the Mechanism of Head Breakdown in Cavitating InJ) ducers, Trans. ASME, J. Basic Eng., pp. 291-305, June 1964.

James, Russell, Steam-Water Critical Flow through Pipes, Proc. Instr. 6 Mech. Engrs., 176(26): 741-748 (1962).

Johnson, A. I.; Hamielec, A. E.; Houghton, W. T.; Mass Transfer with

6 Chemical Reaction from Single Gas Bubbles, A.I.Ch.t'. Journal, 13(2): 379-383 (March 1967).

Karplus, H. B., Propagation of Pressure Waves in a Mixture of Water and 6 Steam, Report ARF-4132-12, Armour Research Foundation, January 1961.

Kirkaldy, J. S., The Time-Dependent Diffusion Theory for Condensation on (1) Spherical and Plane Surfaces, Can. J. Phys., 36: 446-455 (1958).

X'Lamb, H., The Early Stages of a Submarine Explosion, Phil. Mag., Series $6,45: 257-265$ (1923).

bLeFevre, E. J., and Rose, J. W., A Theory of Heat Transfer by Dropwise 10 Condensation, Proceedings of the Third International Heat Transfer Conference Held in Chicago, August '7-12, 1966, VoL. 11 , pip. 36́2-375. 
Ueibson, I.; Holcomb, E. G.; Cacoso, A. G.; and Jacmic, J. J.; Rate of $\checkmark$ Flow and Mechanics of Bubble Formation from Single Submerged Orifices, A.I.Ch.E. Journal, 2(3): 296-306 (September 1956).

A Leonard, J. H., and Houghton, G., Mass Transfer and Velocity of Rise 6 Phenomena for Single Bubbles, Chem. Eng. Sci., 18: 133-142 (1963).

A Levenspiel, 0., Collapse of Steam Bubbles in Water, Ind. Eng. Chem., (f. 51(6): 787-790 (June 1959).

凤 Levich, V. G., Physicochemical Hydrodynamics (translated by Scripto 6 Technica, Inc.), Prentice Hall, 1962.

Levinson, N., On the Asymptotic Shape of the Cavity Behind an Axially

$\uparrow$ Symmetric Nose Moving Through an Ideal Fluid, Ann. Math., Series 2, 47.(4): 704-730 (October 1946).

Levy, S., Prediction of Two-Phase Critical Flow Rate, USAEC Report GEAP4395, General Electric Company, October 1963.

Lightioot, E. N.; Massot, C.; and Irani, F.; Approximate Estimation of $\wedge$ Heat and Mass Transfer Coefficients, Selected Topics in Transport Phenomena, Symposium Series 58, A.I.Ch.E., 61: 28-60 (1965).

$\eta$ Mahoney, J. F., and Wenzel, L. A., Formation of Moderate-Size Bubbles, N A.I.Ch.E. Journal, 9(5): 641-645 (September 1963).

Marshall, D., and Stanton, T. E., On the Eddy System in the Wake of Flat N Circular Plates in Three Dimensional Flow, Proc. Roy. Soc. London, Series A, pp. 295-301, March 1931.

Martin, Joseph J., and Hon, Y-Chun, Development of an Equation of State for Gases, A.I.Ch.E. Journal, 1(2): 142-15! (1955).

NMendelson, Harvey D., The Prediction of Bubble Terminal Velocities from Wäve Theory, A.I.Ch.E. Journal, 13: 250-253 (March 1967).

NMiyagi, Otogoro, The Motion of an Air. Bubble Rising in Water, Phil. Mag., 50: 112-140 (July 1925).

Moody, F. J., Liquid/Vapor Action in a Vessel during Blowdown, USAEC

Report APED-5177, General Electric Company, June 27, 1966.

doody, F. J., Maximum Flow Rate of a Single Component, Two-Phase Mixture, Trans. ASME, J. Heat Transfer, pp. 134-142, February 1965.

RMoore, B. W., The Rise of a Gas Bubble in a Viscous Liquid, J. Fluid Mech., $6(1)$ : 113-130 (July 1959).

Welson, L. C., and Obert, E. F., Generalized.PVT Properties of Gases, Trans. ASME, October 1954. 
V Nishiwaki, Ichiro, Brief Survey on Growth and Collapse of Steam Bubbles, USAEC Report TID-11060, October 1960.

30'Brien, M. P., and Gosline, J. E., Velocity of Large Bubbles in Vertical 4 Tubes, Ind. Eng. Chem., 27(12): 1436-1440 (December 1935).

Padmavathy, P.; Kumar, R.; Kuloor, N. R.; Effect of Orifice Submergence fon Bubble Formation in Horizontal Orifices, Indian J. Tech., 3(4): 133-134 (April 1965).

LPeebles, F. N., and Garber, H. J., Studies on the Motion of Gas Bubbles Pf in Liquids, Chem. Eng. Progr., 49(2): 88-97 (February 1953).

Plesset, M. S., Equations of Motion and Boundary Conditions for Vapor 4 Bubble Dynamics, Proceedings of Conference on Boiling and Two Phase Flow 8 for Heat Transfer Engineers, Berkeley/Los Angeles, California, AED Conf65-124-18, May 1965.

Plesset, M. S., Physical Effects in Cavitation and Boiling, Symposium on ANaval Hydrodynamics, F. S. Sherman (Ed.), Publication 515, pp. 297-323, National Academy of Sciences - National Research Council, Washington, D.C., 1957.

40 Plesset, M. S., The Dynamics of Cavitation Bubbles, J. Appl. Mech.; pp. 277-282, September 1949.

Plesset, M. S., On the Stability of Fluid Flows with Spherical Symmetry, क) J. Appl. Phys., 25(1): 96-98 (January 1954).

Plesset, M. S., and Hsieh, Din-Yu, Theory of Gas Bubble Dynamics in Os90illating Pressure Fields, Phys. Fluids, 3(6): 882-893 (December 1960).

Plesset, M. S., and Mitchell, T. P., On the Stability of the Spherical o) Shape of a Vapor Cavity in a Liquid, Quart. Appl. Math., 13(4): 419-430, (1956).

Plesset, M. S., and Zwick, S. A., A Nonsteady Heat Diffusion Problem with of Spherical symuetry, J. Appl. Phys., 23(1): 95-98 (January 1952).

of Plesset, M. S., and Zwick, S. A., The Growth of Vapor Bubbles in Superof heated Liquids, J. Appl. Phys., 25(4): 493-500 (April 1954).

Poritsky, H., The Collapse or Growth of a Spherical Bubble or Cavity in Na Viscous Fluid, Proceedings of the First U.S. National Congress on Applied Mechanics, Chicago, Illinois, pp. 813-821, .Turie 2951.

(Rayleigh, Lord, On the Pressure Developed in a Liquid During the Collapse Qof a Spherical Cavity, Phil. Mag., Series 6, 34: 94-98 (1917).

Redfield, J.A., and Houghton, G., Mass Transfer and Drag Coefficients A for Single Bubbles at Reynolds Numbers of 0.02-5000, Chem. Eng. Sci., 20: $131-139$ (1965). 
Rennie, J., and Smith, W., A Photographic Study of the Formation and Prop9 erties of Large Gas Bubbles and Their Breakdown into Froths, A.I.Ch.E. Chem. Eng., Symposium Series No. 6, pp. 67-73, 95, 1965.

Rohsenow, W. M., Heat Transfer and Temperature Distribution in Laminarof Film Condensation, Trans. ASME, J. Heat Transfer, pp. 1645-1648, November 1956.

Roh'senow, W. M., and Choi, H. Y., Heat, Mass, and Momentum Transfer, Prentice-Hall, 1961.

Saffman, P. G., On the Rise of Small Air Bubbles in Water, J. Fluid Mech., (0) 1: 249-275 (February 1956).

Schlichting, Herman, Boundary Layer Theory (translated by Dr. J. Kestin), ol 4th ed., McGraw-Hill, 1960.

Wchriven, L. E., On the Dynamics of Phase Growth, Chem. Eng. Sci., o 10(112): $1-13$ (1959).

$\eta$ Sedov, L. I., Similarity and Dimensional Methods in Mechanics (translated

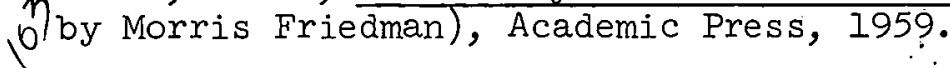

Shu, S. S., Note on the Collapse of a Spherical Cavity in a Viscous In$\alpha$ compressible Fluid, Proceedings of the First U.S. National Congress on Applied Mechanics, Chicago, Illinois, pp. 823-825, June 1951.

$\zeta$ Sideman, S., Direct Contact Heat Transfer Between Immiscible Liquids, (O Advan. Chem. Eng., 6: 207-286 (1966).

Skinner, L. A., and Bankoff, S. G., Dynamics of Vapor Bubbles in Binary

6 Liquids with Spherically Symmetric Initial Conditions, Phys. Fluids,

7(5): 643-648 (May 1964).

Skinner, L. A., and Bankoff, S. G., Dynamics of Vapor Bubbles in Spheri$\bigwedge$ cally Symmetric Temperature Fields of General Variation, Phys. Fluids, $107(1): 1-6$ (January 1964).

Stewart, W. E., Dimensional Analysis and Interphase Transport, Selected

(4) Topics in Transport Phenomena, Symposium Series 58, A.I.Ch.E., 61: 16-27 (O (1965).

A Skinner, L. A., and Bankoff, S. G., Dynamics of Vapor Bubbles in General Temperature Fields, Phys. Fluids, 8(8): 1417-1420 (August 1965).

Trilling, Leon, The Collapse and Rebound of a Gas Bubble, J. Appl. Phys., ( 23(1): 14-17 (January 1952).

Valentin, F. H. H., Absorption in Gas-Liquid Dispersions, E \& F. N. Spon, Ltd., London, 1967. 
$\checkmark$ Vandegrift, A. E., Water May Have No Dynamic Surface Tension, Ind. Eng. ) Chem., 59(4): 9 (April 1967).

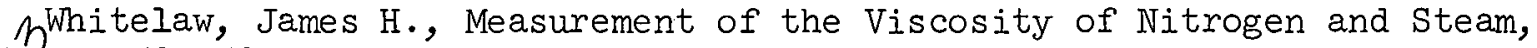
1 pp. 52l-526 in Progress of International Research on Thermodynamics and Transport Properties, Held January 24-36, 1962, at Princeton. University, J. F. Masi and D. H. Tsai (Eds.), ASME.

WWittke, D. D., and Chao, B. T., Collapse of Vapor Bubbles with Translatory ('Motion, Paper No. 66-WA/HT-12 (Preprint), J. Heat Transfer, Trans. ASME, June 1966.

'́zaloudek, F. R., The Low Pressime Critical Discharge of Steam-Water Mix\'tures from Pipes, USAEC Report HW-68934 Rev., Hanford Atomic Products Operation, March 1961.

Zaloudek, F. R., Steam-Water Critical Flow from High Pressure Systems, (I USAEC Report HW-80535, Hanford Atomic Products Operation, January, 1964. Zaloudek, F. R., The Critical Flow of Hot Water Through Short Tubes, (IUSAEC Report HW-77594, Hanford Atomic Products Operation, May 1963.

bZieminski, S. A.; Caron, M. M.; Blackmore, R. B.; Behavior of Air Bubbles ( in Dilute Aqueous Solutions, Ind. Eng. Chem., 6(2): 233-242 (May 1967).

OZwick, S. A., and Plesset, M. S., On the Dynamics of Small Vapor Bubbles in Liquids, J. Math. Phys., 33: 308-330 (1954):

plwick, S. A., Growth of Vapor Bubbles in a Rapidly Heated Liquid, $\checkmark$ California Institute of Technology, Engineering Division Report No. 85-13, September 1959.

Zwick, S. A., The Growth and Collapse of Vapor Bubbles, Report AD-54059, NDecember 1954 .

\section{Additives}

NBurger, L. L., Physical Chemistry of the Hydrazine-Methyl Iodide Reaction, $V$ USAEC Report BNWL-404, pp. 105-106, Pacific Northwest Laboratory, March 1967.

Mehta, D. S., and Calvert, S., Gas Sorption by Suspensions of Activated NCarbon in water, Envir. Sci. Tech:, 1(4): 325-331 (April 1967).

Mishima, J.; Schwendiman, L. C.; Burger, L. L.; Hasty, R. A.; Removal of Methyl Iodide From Simulated Reactor Containment Atmospheres with Hydrazine, Proceedings of the Ninth AEC Air Cleaning Conference, USAEC Report CONF-660904, Vol. 1, pp. 298-316, 1966. 
$\sqrt{ }$ Oak Ridge National Laboratory, Status and Progress Report, USAEC Report ORNL-4067, p. 23, December 1966.

Y Schwendiman; I. C., a report in Progress Summary of Nuclear Safety Research and Development Projects, Nucl. Safety, 8(3): 267 (Spring 1967).

Viles, F. J., Jr., and Silverman, L., Removal of Iodine and Methyl Iodide $V$ by Aerosol Formation with Hydrazines, Proceedings of the Ninth AEC Air Cleaning Conference, USAEC Report CONF-660904, Vol. 1, pp. 273-297, 1966.

\section{Fission Products}

N

Adams, R. E., Characterization, Control, and Simulation of Accident-Released Fission Products, Nucl. Safety, 7(4): 502 (Summer 1966).

Adams, R. E.; Bennett, R. L.; Browning, W. E., Jr.; Characterization of

V. Volatile Forms of Iodine at High Relative Humidity by Composite Diffusion Tubes, USAEC Report ORNL-3985, Oak Ridge National Laboratory, August 1966.

PAdams, R. E., and Browning,. W. E., Jr., Removal of Radioiodine From Gases it Elevated Temperatures, USAEC Report' CONF-12-3, June 17, 1962.

Adams, R. E.; Browning, W. E., Jr.; Cottrell, W. B.; Parker, G. W.; The n- Release and Adsorption of Methyl Iodide in the HFIR Maximum Credible AcN cident, USAEC Report ORNL-TM-1291, Oak Ridge National Laboratory, Oct.. I, 1965.

Atkins, D. H. F., and Arkell, G. M., The Preparation of Radioiodine La-.

$\hat{h}$ bel.led Methyl Iodide by an Exchange Process, British Report AERE-R-4823, June 1965.

$\eta$ Atkins, D. H. F., and Eggleton, A. E. J., Iodine Compounds Formed on Re$\eta$ lease of Carrier-Free Iodine-131, British Report AERE-M-1211, May 1963.

- Browning, W. E., Jr., and Ackley, R. D., Characterization and Control of NAccident-Released Fission Products, pp. 26-3I in Nuclear Safety Program

7 Semiannual Progress Report for Period Ending June 30, 1963, USAEC Report ORNL-3483, Oak Ridge National Laboratory.

i Browning, W. E., Jr., et al., Nuclear Safety Program Semiannual Progress

$\eta$ Report for Period Ending Dec. 31, 1964, USAEC Report ORNL-3776, Oak Ridge

National Laboratory.

Browning, W. E., Jr.; Miller, C. E., Jr.; Roberts, B. F.; Shields, R. P.;

$\checkmark$ Release of Fission Products on In-Pile Melting of Reactor Fuels, pp. 29-38

$\eta$ in Nuclear Safety Program Semiannual Progress Report for Period Ending

June 30, 1962, USAEC Report ORNL-3319, Oak Ridge National Laboratory, August 1962. 
Browning, W. E., Jr.; Miller, C. E., Jr.; Roberts, B. F.; Shields, R. P.;

$\eta \begin{aligned} & \text { Release of Fission Products on the In-Pile Melting or Burning of Reactor } \\ & \text { Fuels, pp. } 27-35 \text { in Nuclear Safety Program Semiannual Progress Report for }\end{aligned}$

$\eta$ Period Ending Dec. 31, 1962, USAEC Report ORNL-3401, Oak Ridge National Laboratory.

Browning, W. E., Jr.; Miller, C. E., Jr.; Roberts, B. F.; Shields, R. P.; ABehavior of Fission Products Released During In-Pile Destruction of ReSactor Fuels, pp. 42-59 in Nuclear Safety Program Semiannual Progress Report for Period Ending Dec. 31, 1963, USAEC Report ORNL-3547, Oak Ridge National Laboratory.

Cast.leman, A. W., Jr.; Tang, I. N.; Munkelwitz, H. R.; Chemical State of GIodine Released From Irradiated Fuels Into Steam, Proceedings of Inter-

1 national Symposium on Fission Product Release and Transport Under Accident

1 Conditions, Held at Oak Ridge, Tennessee, April 5-7, 1965, USAEC Report CONF-650407, Vol. 2, pp. 1118-1130, 1965.

Chamberlain, A. C., Physical Chemistry of Iodine and Removal of Iodine (N From Gas Streams, British Report AERE-R-4286, April 1963.

Clough, W. S.; Cousins, L. B.; Eggleton, A. E. J.; Radioiodine Adsorption on Particulate Matter, Proceedings of International Symposium on Fission

N Product Release and Transport Under Accident Conditions, Held at Oak Ridge, Tennessee, April 5-7, 1965, USAEC Report CONF-650407, Vol. I, pp. 242-275.

Nraig, D. K., An Investigation of the Interactions That Occur Between $I_{2}$ : $\times$ Radionuclides and an Iron Oxide Aerosol in the Respirable Size Range, Health Phys., 12(8): 104'7-106\% (August 1966):

Croft, J. F.; Iles, R. S.; Davis, R. E.; Experiments on the Surface Depo(10) sition of Airborne Iodine of High Concentration, British Report AEEW-R-265, June 1963.

Wavis, M. E., et al., The Depnsition of Fission Product Iodine on Structural Surfaces, Proceedings of International Symposium on Fission Product

) Reledse dru Trarisport Under Accident Conditions, Held at Oak Ridge, Tennessee, April 5-7, 1965, USAEC Report CONF-650407, Vol. 2, pp. 730-746. )

Hehols, W. H., and Young, J. A., Studies of Portable Air-Operated Aerosol 、Generators, NRL Report 5929, U.S. Naval Research Laboratory, July 26, 1963.

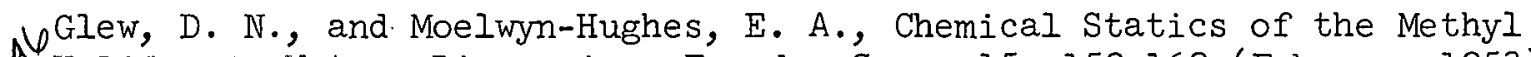
1) ${ }^{4}$ Halides in Water, Discussions Faraday Soc., 15: 150-160 (February 1953).

AGriffiths, V., The Removal of Iodine From the Atmosphere by Sprays, British Report AHSB(S)-R-45, January 1963.

May, F. G., and Morris, J. B., Performance of the BEPO Scrubber for Iodine Removal, British Report AERE-M-1163, February 1963. 
o Morris, J. B.; Diffey, H. R.; Nicholls, B.; Rumary, C. H.; The Removal

$\alpha$ of Low Concentrations of Iodine From Air on a Plant Scale, British Report AERE-R-3917, December 1961.

Morris, J. B., and Nicholls, B., The Deposition of Iodine Vapour on Sur-

h faces, Proceedings of International Symposium on Fission Product Release

$y$ and Transport Under Accident Conditions, Held at Oak Ridge, Tennessee, April 5-7, 1965, CONF-650407, Vol. 1, pp. 142-177.

A Morris, J. B., and Rumary, C. H., Tests on Absorbers for Iodine at Low Concentrations, British Report AERE-R-4219, February 1963.

Parker, G. W.; Martin, W. J.; Creek, G. E.; Barton, C. J.; Behavior of

Nadio-iodine in the Containment Mockup Facility, Proceedings of Interna-

7 tional Symposium on Fission Product Release and Transport Under Accident

Conditions, Held at Oak Ridge, Tennessee, April 5-7, 1965, CONF-650407, Vol. 1, pp. 212-241.

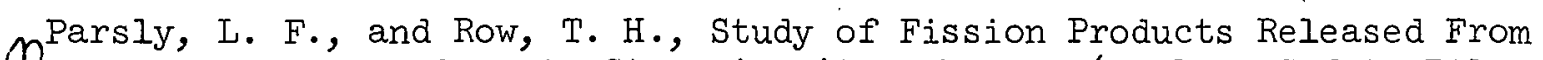

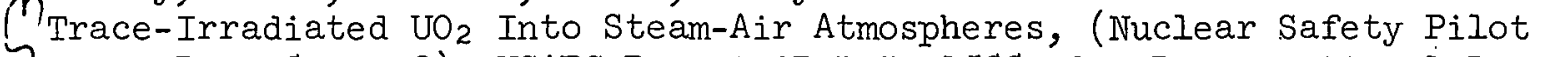

Plant Runs 8 and 9), USAEC Report ORNL-TM-1588, Oak Ridge National Laboratory, May 20, 1966.

Silverman, M. D..; Truitt, J.; Browning, W. E., Jr., Franzen, L. F.;

NCharacterization of Radioactive Particulate Aerosols by the. Fibrous Filter Analyzer, USAEC Report ORNL-4047, Oak Ridge National Laboratory, March 1967.

GSmith, M. I., Confinement Test Results for Development Test RL-REA-1093,

$\checkmark$ Report. RL-REA-2548, September 1965.

N Taylor, R. F., Absorption of Iodine Vapor by Aqueous Solutions, Chem.

Eng. Sci., 10(1/2): 68-79 (April 1959).

Watson, L. C.; Bancroft, A. R.; Hoelke, C. W.; Iodine Containment by Dousing in NPD-II; Canadian Report CRCE-979, Oct. 27, 1960.

No

Whittaker, E. I., and Bretthauer, E. W., Sampling Airborne Radioiodine

in Organic Compounds, Nucl. Appl., 2(1): 55-56 (February 1966). 


\section{Appendix B \\ REVIEW COMMITTEES AND CONSULTANTS}

AEC, Germantown

Andrew J. Pressesky

AEC Review Committee

H. L. Hamester, RDT

R. R. Newton, RDT

Battelle Memorial Institute

D. L. Morrison

General Electric Company, Nuclear Division

C. F. Falk

Oak Ridge National Laboratory

J. R. Buchanan

W. B. Cottrell

E. N. Cramer

F.' I. Culler

R. J. Davis

L. F. Parsly

G. W. Parker

H. B. Piper

R. W. Schneider

J. H. Swanks

G. M. Watson

Oak Ridge National Laboratory, Internal Review Committee

R. E. Adams

R. H. Bryan

C. A. Burchsted

C. D. Cagle

M. H. Fontana

A. B. Fuller

J. W. Michel 
Pacific Gas and Electric; Steam Generation Department

P. Matthew

Phillips Petroleum Company, Plant Applications and Engineering Test Branch

N. J. Sowards

Phillips Petroleum Company, Water-Reactor Safety Program Office

F. S. Schroeder

Westinghouse Electric Corporation

John McAdoo

Robert Wieseman

External Review Committee

A. H. Peters, Savannah River Laboratory Rogers McCullough; Southern Nuclear

Engineering Company

M. W. First, Harvard Air Cleaning

Laboratory

B. Y. H. Liu, University of Minnesota 